\title{
Unión de variantes de la Apolipoproteína A-I a ligandos celulares induciendo amiloidosis.
}

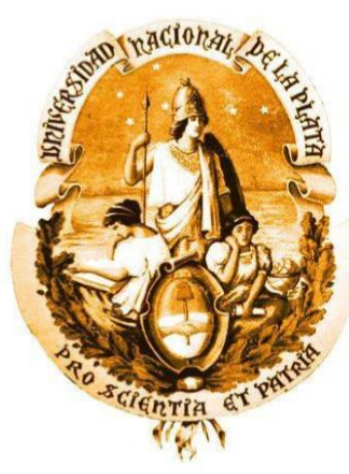

\section{Tesis doctoral}

Tesista: Lic. Gaddi, Gisela Marina.

Directora: Dra. Tricerri, María Alejandra.

Co director: Dr. Ramella, Nahuel Alberto. 
El presente trabajo de tesis, para optar al grado de Doctor en Ciencias Médicas de la Universidad Nacional de La Plata, fue realizado en el Instituto de Investigaciones Bioquímicas de La Plata (INIBIOLP), Facultad de Ciencias Médicas, Universidad Nacional de La Plata, bajo la dirección de la Dra. M. Alejandra Tricerri y la co-dirección del Dr. Nahuel A. Ramella.
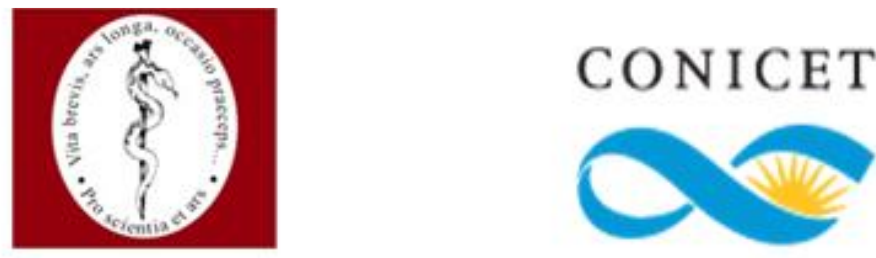

INIBIOLP

Universidad Nacional de La Plata

Facultad de Ciencias Médicas 
Para Lourdes Abril:

En este poco tiempo de tu vida me ha demostrado fortaleza y ganas de salir adelante. Hija mía gracias por hacerme recordar esos grandes valores.

Seguiremos aprendiendo juntas en este largo camino llamado vida. 
Agradecimientos:

A mi directora Dra María Alejandra Tricerri, quien ha confiado en mí para llevar a cabo esta tesis doctoral y me ha acompañado en este proceso.

A mi co director Dr Nahuel Ramella quien ha tomado el lugar del Dr Omar Rimoldi para guiarme y ayudarme en este trabajo.

Al Dr Horacio Garda y al INIBIOLP por brindarme el espacio físico para desarrollar mi tesis.

A las instituciones que hicieron posible el financiamiento de esta tesis:

CONICET, AGENCIA y la Universidad Nacional de La Plata.

A Gabriela quien me ayudo en varios experimentos, especialmente en el cultivo celular, además de ser una gran compañera de trabajo.

A las chicas del laboratorio 11 con quienes compartí gratos momentos de trabajo: Fernanda, Romina, y Silvana, gracias por su compañerismo y los mates compartidos.

A todos los integrantes del INIBIOLP, pero no puedo dejar de mencionar a varias personas: Ana Rodriguez, Wilson, Ivo, Agustina, Elizabeth, Marianela, Leticia Aguirre, etc, gracias por darme una mano cuando lo necesité, no solo al nivel profesional sino también personal.

A Emiliano por ser mi compañero en estos 12 años, gracias por brindarme tu amor y contención en estos 5 años, sin tu apoyo, este trabajo me hubiera sido imposible, por nuestro proyecto de familia que estamos comenzando.

A mi abuela Nilda que ya no está pero la recuerdo con emoción y alegría, gracias por compartir mi infancia y adolescencia.

A mi mamá, mi hermana Yamila, que están ahí desde siempre y José gracias por estar presente.

A mi papá, que ha sido un gran apoyo y Silvina, gracias por ser una buena madre para mis hermanos Máximo, Lucio e Isabella y ser buena persona. A la familia que gané en estos 12 años: Cecilia, Ricardo, Verónica, Hernan, Valentina, Claudia, Francisco y Choly, gracias por recibirme desde el primer día.

A mis amigos Vane, Cele, Cin, Javi, Nere, Lujan, Javo, y Mariano. Gracias por su amistad incondicional.

A Elida, mi vecina que me brindo su cariño desde el primer momento. 


\section{RESUMEN}

La apolipoproteína A-I (ApoA-I) es un componente mayoritario de las lipoproteínas de alta densidad humanas (HDL), cuyos niveles elevados se correlacionan negativamente con el riesgo de sufrir enfermedades cardiovasculares. Un extenso campo de investigación atribuye la alta eficiencia de la ApoA-I a su participación en numerosas vías metabólicas que promueven el transporte reverso de colesterol y la protección de la función endotelial. A pesar de ello diferentes variantes naturales de la ApoA-I presentan una mutación puntual en la secuencia proteica (ya sea sustitución ó deleción), y se encuentran presentes en depósitos patológicos de amiloide. Al momento fueron descriptas más de 50 variantes naturales de esta proteína, de las cuales más de un tercio son asociadas con amiloidosis familiar. Un número importante de estas mutaciones se identifican en la región $\mathrm{N}$-terminal (residuos 26-100) y su cuadro clínico se asocia principalmente con daño renal y hepático.

Desde la descripción temprana de las diferentes variantes naturales, se ha investigado para arrojar luz sobre los eventos que determinan su depósito y el concomitante daño orgánico resultante. En este trabajo estudiamos y comparamos el efecto que la mutación pueda inducir en dos variantes naturales $\mathrm{N}$-terminales de ApoA-l: la mutante surgida de una sustitución de Triptófano por Arginina en posición 50 (W50R, descripta en lesiones glomerulares renales), y la resultante del reemplazo de una Leucina en la posición 60 por una Arginina (L60R), la cual se encuentra involucrada en la formación de depósitos amiloides túbulo intersticiales.

Los estudios involucraron una exhaustiva caracterización biofísica de la estructura de ambas variantes comparadas a la proteína con la secuencia nativa (Wt). Análisis de dicroísmo circular, fluorescencia y microscopía permitieron definir que a pesar de involucrar mutaciones de similar naturaleza química (reemplazo de un amino ácido no polar por uno positivo en el extremo N), la perturbación estructural que ocurre en W50R es sutil. En cambio, L60R adquiere una conformación más inestable, con pérdida de estructura secundaria y con mayor tendencia a la agregación. Más aún y quizá como consecuencia de lo 
anterior, esta variante es más susceptible a ser proteolizada, lo que pueda implicar un catabolismo incrementado ó la posibilidad de liberación de algún péptido que pueda per se poseer mayor tendencia a la agregación que la proteína con la secuencia completa.

A continuación nos propusimos considerar el efecto de las modificaciones estructurales observadas en la interacción que pueda sufrir la ApoA-I con ligandos naturales. La alta flexibilidad estructural de esta proteína le permite interactuar con membranas biológicas adaptando su conformación, desde estructuras libre de lípidos hasta otras lipidadas, formando parte de las lipoproteínas de alta densidad humana (HDL). La utilización de un modelo de lípido negativo (dodecil sulfato de sodio) nos permitió evidenciar que incluso la proteína Wt podría dar lugar a conformaciones pro-amiloidogénicas ante compuestos o metabolitos circulantes. Más aún, es conocido que distintos cambios de situaciones fisio-patológicas podrían modificar la interacción con el microambiente. Así, analizamos el efecto de un ligero descenso de pH (como puede ocurrir en eventos pro-inflamatorios) sobre la interacción de las variantes con componentes de la matriz extracelular. Es sabido que los proteoglicanos (y sus glucosamino glicanos (GAGs) asociados, podrían favorecer la retención y/o agregación de proteínas. Usando como modelo de GAG a la heparina, pudimos determinar que ante un descenso de $\mathrm{pH}$ se incrementa la retención relativa de la variante W50R como compuesto pro-amiloide. Dada la riqueza de GAGs con alta carga negativa en los glomérulos, es importante sugerir que la razón de la presencia de esta variante en la corteza renal pueda deberse a su mayor retención local.

Por último nos propusimos evaluar la hipótesis que los cambios conformacionales observados puedan resultar en una estructura que pueda generar el reconocimiento del sistema inmune innato despertando una respuesta pro-inflamatoria.

Demostramos que en las condiciones experimentales ensayadas, L60R (pero no W50R) activa un modelo de macrófagos humanos, los cuales liberan el factor de necrosis tumoral a y la interleuquina-1 $\beta$. Esta observación podría implicar que la generación de una respuesta pro inflamatoria podría incrementar y/o perpetuar la lesión. 
Como conclusión, los resultados mostrados en este trabajo permiten determinar que los eventos involucrados en la agregación patológica de variantes $\mathrm{N}$ terminales de la ApoA-I no son universales a pesar de ser las mutaciones de naturaleza química similar. Mientras que modificaciones leves en la estructura de la variante W50R modificarían su unión (y probable retención) con probables ligandos fisiológicos, la variante L60R experimenta alteraciones conformacionales que incrementan su agregación, grado de proteólisis y disparan la respuesta inflamatoria en un modelo de macrófagos humanos. Estos resultados sugieren fuertemente que la enfermedad crónica puede ser la consecuencia de una pérdida de estructura nativa de las proteínas, lo que rinde conformaciones que pueden ser citotóxicas o precursores de complejos amiloides. Sientan a su vez la base para futuras líneas de investigación que permitan establecer la génesis de la amiloidosis debida a ApoA-I y la órgano especificidad. 
Los resultados presentados en este trabajo, han sido en parte divulgados en las siguientes publicaciones:

1. Structural analysis of a natural apolipoprotein A-I variant (L60R) associated with amyloidosis. Gaddi GM, Gisonno RA, Rosú SA, Curto LM, Prieto ED, Schinella GR, Finarelli GS, Cortez MF, Bauzá L, Elías EE, Ramella NA, Tricerri MA. Arch Biochem Biophys. 2020 Mar 16:108347. doi: 10.1016/j.abb.2020.108347

2. Fibrillar conformation of an apolipoprotein A-I variant involved in amyloidosis and atherosclerosis. Gisonno RA, Prieto ED, Gorgojo JP, Curto LM, Rodriguez ME, Rosú SA, Gaddi GM, Finarelli GS, Cortez MF, Schinella GR, Tricerri MA, Ramella NA. Biochim Biophys Acta Gen Subj. 2020 Apr;1864(4):129515. doi: 10.1016/j.bbagen 


\section{INDICE}

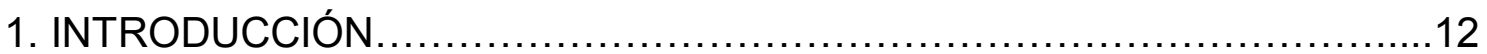

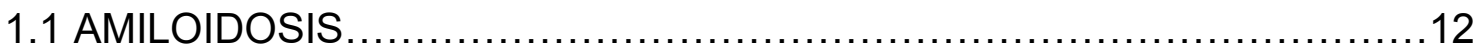

1.2 ESTRUCTURA DE LA APOLIPOPROTEÍNA A-I..........................13

1.3. FUNCIÓN DE LA APOLIPOPROTEÍNA A-I...............................17

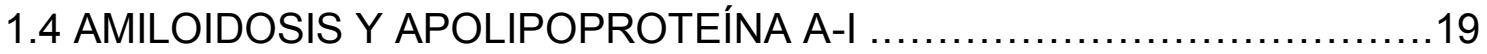

1.5 AMILOIDOSIS RENAL POR APOLIPOPROTEÍNA A-I .......................22

1.6 RESPUESTA INFLAMATORIA EN ENFERMEDADES RENALES

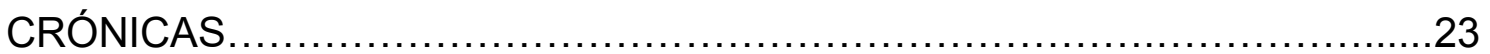

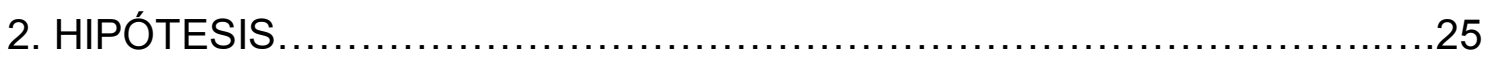

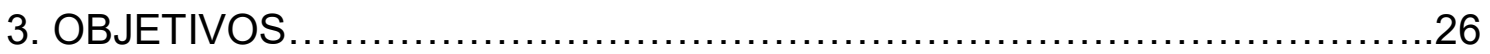

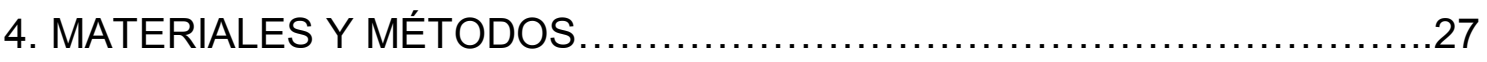

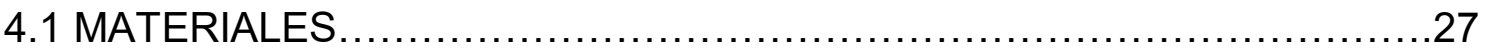

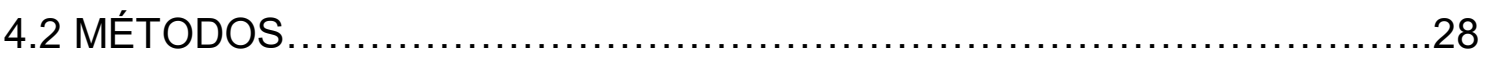

4.2.1 CONSTRUCCIÓN DE LAS VARIANTES DE APO A-I POR

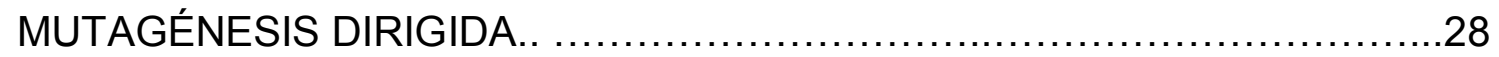

4.2.2 EXPRESIÓN DE VARIANTES DE APOA-I EN CULTIVOS DE

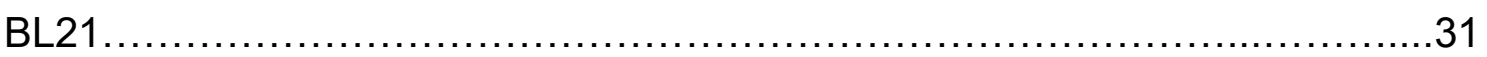

4.2.3 PURIFICACIÓN DE VARIANTES NATURALES DE APO A-I ..............31

4.2.4 TÉCNICAS ELECTROFORÉTICAS ......................................32

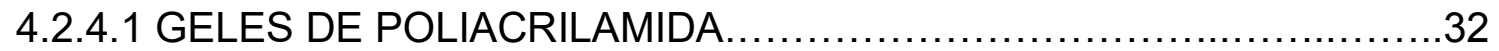

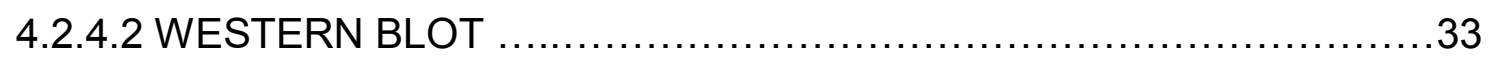

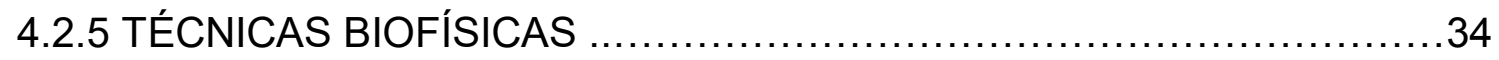

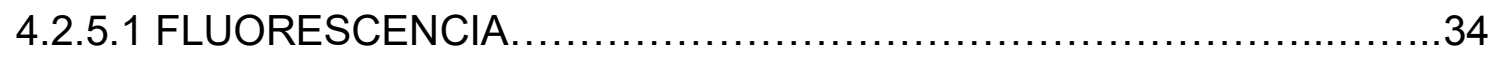

4.2.5.2 DESNATURALIZACIÓN CON GUANIDINA CLORHIDRICA ..............36

4.2.5.3 APAGADO (QUENCHING) FLUORESCENCIA CON

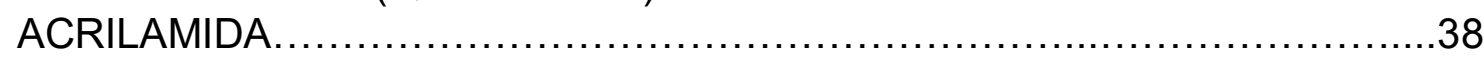

4.2.5.4 FLUORESCENCIA DE BIS ANS.......................................

4.2.5.5 DETECCIÓN DE AGREGADOS PROTEICOS POR TIOFLAVINA T. . 39 
4.2.5.6 PLEGAMIENTO EN PRESENCIA DE UREA..........................40

4.2.5.7 UNIÓN A LIGANDOS CELULARES ..................................40

4.2.5.8 DICROISMO CIRCULAR..................................................... 41

4.2.5.9 CROMATOGRAFÍA LÍQUIDA DE ALTA RESOLUCIÓN................43

4.2.5.10 VISUALIZACIÓN DE AGREGADOS PROTEICOS ......................43

4.2.5.10.1 MICROSCOPÍA DE TRANSMISIÓN ELECTRÓNICA..................43

4.2.5.10.2 MICROSCOPÍA DE FUERZA ATÓMICA..............................43

4.2.5.11 ENSAYO DE FUNCIONALISMO. ACLARAMIENTO DE LIPOSOMAS

DE DI MIRISTOIL FOSFATIDIL COLINA (DMPC) ............................4

4.2.6 PROCESAMIENTO PROTEOLÍTICO DE APO A-I Y SUS

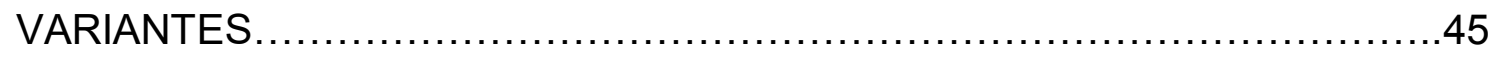

4.2.7 ACTIVACIÓN DE MACRÓFAGOS HUMANOS .............................45

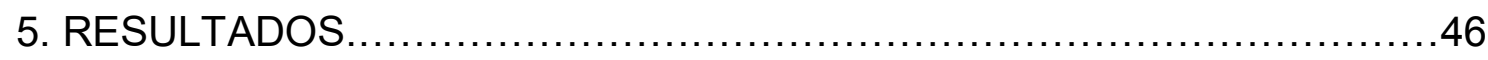

5.1 PURIFICACIÓN DE APO A.I Y SUS VARIANTES

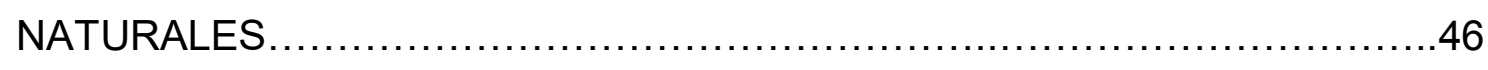

5.2 COMPARACIÓN ESTRUCTURAL Y ESTABILIDAD ........................47

5.3PROCESAMIENTO PROTEOLÍTICO DE APO A-I Y SUS

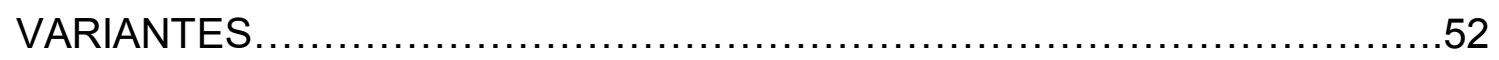

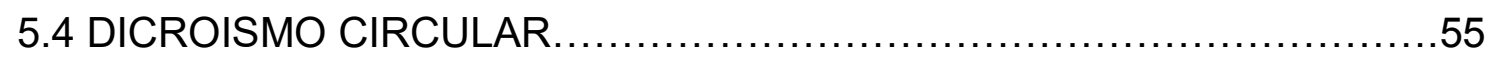

5.5 ESTUDIO DEL EQUILIBRO DÍMERO-MONOMERO DE APO A-I Y SUS

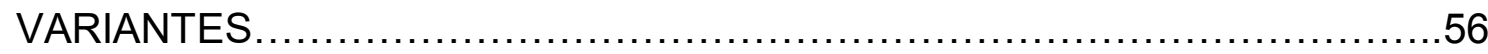

5.6 ENSAYOS DE AGREGACIÓN DE APO A-I ..............................60

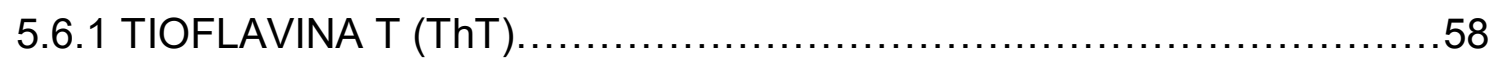

5.6.2 VISUALIZACIÓN DE COMPLEJOSAMILOIDES..........................60

5.6.3 EFECTO DE LA UREA SOBRE LA AGREGACIÓN.........................62

5.6.4 UNIÓN A LIGANDOS CELULARES .......................................63

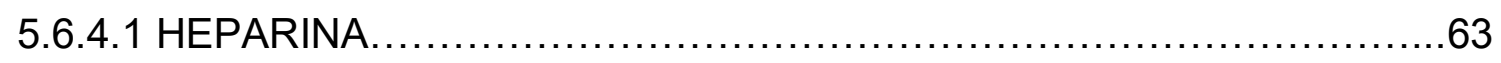

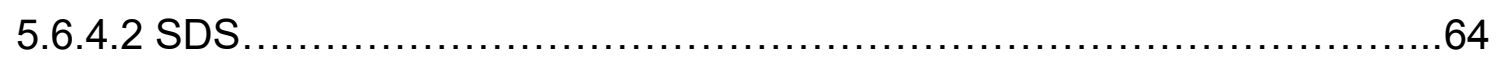

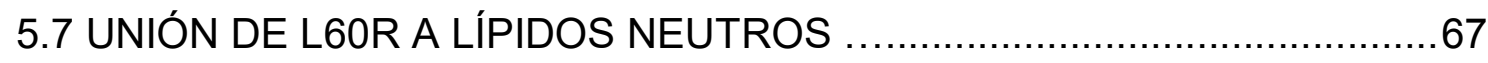

5.8 RESPUESTA INFLAMATORIA MEDIADA POR APO A-I Y SUS

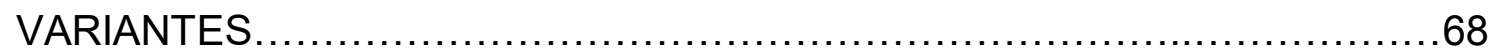

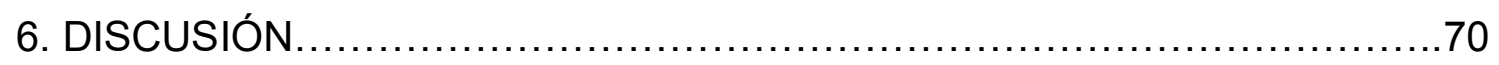

6.1PERTURBACIONES ESTRUCTURALES DE LAS VARIANTES

NATURALES DE APO A-I. ................................................. 
6.2. PROCESAMIENTO PROTEOLÍTICO DE APO A-I Y SUS

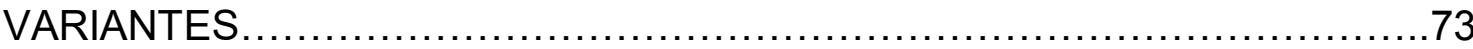

6.3 EVALUACIÓN DE LA RELACIÓN ESTRUCTURA FUNCIÓN................76

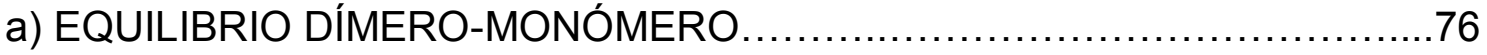

b) SOLUBILIZACIÓN DE LÍPIDOS .................................................

6.4 UNIÓN A LIGANDOS CELULARES DE APO A-I Y SUS

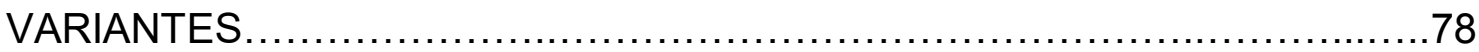

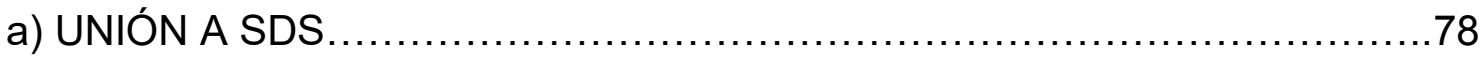

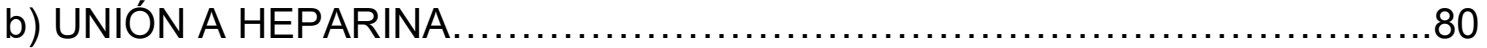

6.5 ACTIVACIÓN DE RESPUESTA INFLAMATORIA DE APO A-I Y SUS

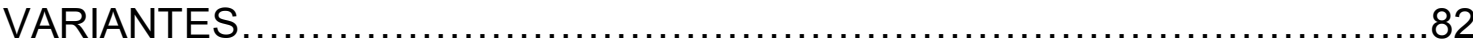

7 CONCLUSIONES GENERALES DE LOS MECANISMOS

AMILOIDOGÉNICOS DE LAS VARIANTES N- TERMINALES DE APO A-I....84

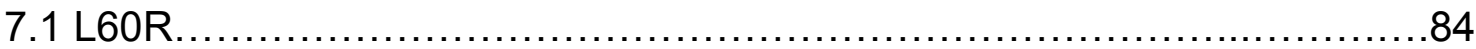

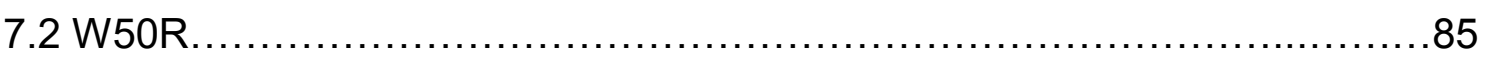

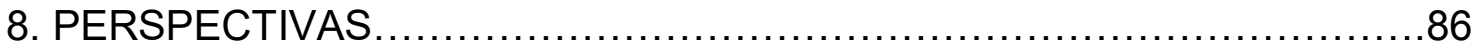

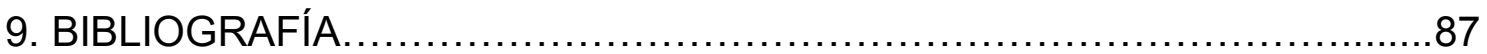




\section{INTRODUCCIÓN}

\subsection{AMILOIDOSIS}

Las amiloidosis constituyen un grupo heterogéneo de enfermedades caracterizadas por la presencia de depósitos de proteínas fibrilares insolubles (amiloides), de naturaleza tóxica y localización extracelular. La formación de dichos depósitos depende no sólo de la tendencia de la proteína a agregarse sino de diversos factores que favorecen a la estabilidad de los agregados proteicos característicos de la patología (Wechalekar AD 2016). Las proteínas involucradas en estos plegamientos tienen en común cierta flexibilidad estructural para llevar a cabo sus funciones biológicas; en consecuencia son más susceptibles a un cambio conformacional promoviendo así su auto agregación; las fibras en los depósitos tisulares poseen en general un diámetro de 7 - $10 \mathrm{~nm}$ y evidencian una birrefringencia verde manzana bajo la luz polarizada cuando se tiñen con rojo Congo (Merlini G 2003, Wechalekar AD 2016).

Las amiloidosis se clasifican en

- Adquiridas: asociadas a una patología de base como desórdenes inmunitarios que provocan la síntesis de proteínas de fase aguda, entre ellas amiloide sérico A (SAA) y amiloidosis por cadenas livianas de inmunoglobulinas.

- Hereditarias o primarias: debido a mutaciones puntuales en diversas proteínas como transtirretina, a sinucleína y apolipoproteínas, entre otras. Más de 20 proteínas sin relación estructural ni funcional están involucradas en la enfermedad (Dember LM 2006, ladanza MG 2018)

Entre los factores que puedan aumentar la tendencia natural de las proteínas a agregarse, pueden mencionarse el descenso de $\mathrm{pH}$ local, oxidación, proteólisis, la unión a ligandos celulares (como glucosaminoglucanos (GAGs) y lípidos negativos) o un aumento de la concentración de metabolitos (crowding).

Todos estos factores pueden influir en que las proteínas cambien la conformación de su estructura hacia un plegamiento anómalo e induzcan su 
agregación, lo que trae en consecuencia depósitos amiloides sobre los órganos blanco generando así la sintomatología clínica correspondiente a la localización de estos agregados (Figura 1.1) (Merlini G 2003, Dember LM 2006).

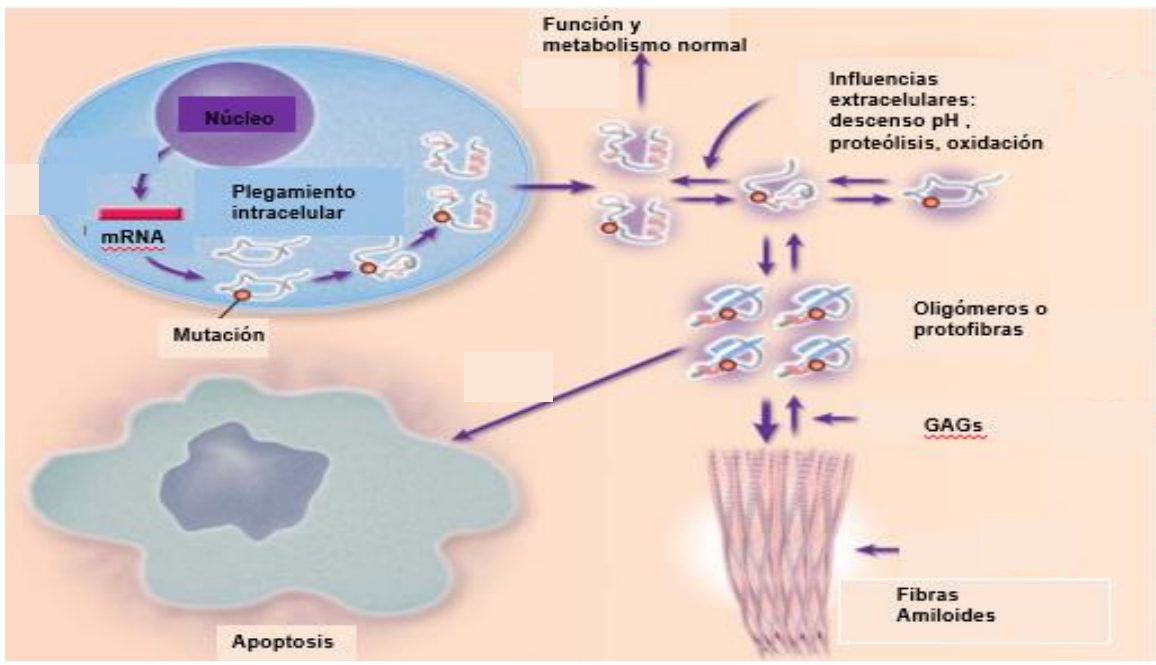

Figura 1.1: Posibles eventos que puedan favorecer o inducir la formación de agregados amiloides. Ya sea por un cambio estructural debido a las mutaciones o por alteración en el micro entorno se podría desviar el equilibrio entre una estructura nativa y otra con mayor tendencia a la agregación (Merlini G 2003).

\subsection{ESTRUCTURA DE LA APOLIPOPROTEÍNA A-I.}

La apolipoproteína A-I (ApoA-I) es el componente proteico mayoritario de las lipoproteínas de alta densidad humanas (HDL), las que participan en el trasporte reverso del colesterol (TRC). La ApoA-I tiene un peso molecular de 28 kDa y una secuencia polipeptídica de 243 aminoácidos. Se expresa en hígado como un pre-pro-péptido de 267 aminoácidos de longitud, el cual es procesado por proteasas dando el pro-péptido de 249 residuos; éste se libera a circulación donde luego experimenta clivaje de una secuencia de 6 aminoácidos, resultando así la ApoA-I madura (Obici L 2006, Scanu AM 1984, Oda MN 2017).

La estructura secundaria está caracterizada por un $65-75 \%$ de $\alpha$ hélices anfipáticas, las cuales poseen una cara polar que permite el contacto con el medio acuoso y una cara apolar que permite la unión con lípidos; las hélices se 
encuentran estabilizadas por la formación de puentes salinos (Oda MN 2017). Según la distribución de los residuos en la proteína se ha establecido una clasificación de a hélices (Figura 1.2):

Clase A: las cargas positivas están en contacto con la interface polar-no polar de la hélice y las cargas negativas en el centro de la cara polar, es la clase más abundante en esta proteína y se sitúan en las regiones 44-65, 66-87, 121-142, $143-164,165-186$ y $187-208$.

Clase $\mathrm{Y}$ : las cargas positivas forman tres grupos que se distribuyen en forma de "Y" uno en el centro de la cara polar y dos en contacto con la interface, está presente en las regiones 88-98, 99-120, 209-219 y 220-241.

Clase $\mathrm{G}^{*}$ : Las cargas positivas y negativas están distribuidas azarosamente en la cara polar y solo está representada en la región entre amino ácidos 8 a 33 (Segrest JP 1992, Oda MN 2017).

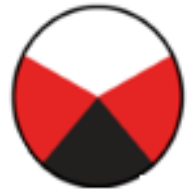

A

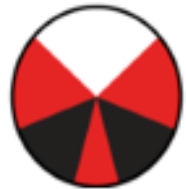

B

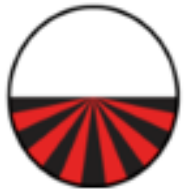

C

Figura 1.2. Clases de hélices anfipáticas de ApoA-I. Representación esquemática mediante el modelo de rueda de "Schiffer-Edmunson" (en dicho modelo supone 3,6 aminoácidos por vuelta de $\alpha$ hélice). A) Clase $A, B$ ) clase $Y, C$ ) clase $G^{*}$. Zonas en rojo corresponden a las cargas positivas, en negro cargas negativas y en blanco corresponden a las zonas hidrofóbicas de las $\alpha$ hélices. (Oda MN 2016, Schiffer M 1967)

Desde el residuo 44 en adelante (a excepción de las secuencias entre 8898 y 209-219 mencionadas arriba) hay 10 repeticiones en tándem de 22 
aminoácidos cada una, las que generalmente se encuentran interrumpidas por residuos prolina (Segrest JP 1992, Gursky O 1996, Oda MN 2017, Mei X 2011).

La ApoA-I presenta una energía libre en ausencia de agente desnaturalizante $\left(\Delta \mathrm{G}^{\circ} \mathrm{H}_{2} \mathrm{O}\right)$ de $\sim 2,4 \mathrm{kcal} / \mathrm{mol}$, lo que corresponde a un estado parcialmente desorganizado, a diferencia de otras proteínas globulares que tienen valores de $\Delta \mathrm{G}^{\circ} \mathrm{H}_{2} 0$ de 5 a $15 \mathrm{kcal} / \mathrm{mol}$. Este fenómeno explica la gran flexibilidad de la estructura terciaria que le permite la unión a lípidos y varios ligandos. Dada las características específicas de su estructura (estructura secundaria nativa bien definida y estructura terciaria laxa), su plegamiento es caracterizado biofísicamente como de glóbulo fundido (Gursky O 1996). En circulación esta proteína se encuentra mayoritariamente unida a lípidos formando las HDL, y una fracción mínima puede reciclarse estando como proteína libre (aproximadamente un $5 \%$ de la ApoA-I total). Dada la mencionada flexibilidad estructural, no fue posible hasta el momento obtener la estructura cristalina de la proteína completa. Recién en el año 2011, Mei y colaboradores (Mei X 2011) cristalizaron una secuencia truncada en el extremo C- de la forma libre obteniendo la estructura $\Delta(185-243)$, como se la puede visualizar en la Figura 1.3. Esta estructura permite predecir:

A) En el estado libre de lípidos, la conformación elongada de la proteína, puede experimentar la conversión entre los estados fisiológicos monómero y dímero estabilizando interacciones entre los extremos $\mathrm{N}$ - y C-, ya sea de la misma molécula en el monómero ó de dos proteínas situadas de manera anti paralela en el dímero.

B) La conformación puede adaptarse en forma de "cinturón", al interactuar caras no polares de las hélices anfipáticas con las cadenas acílicas de los ácidos grasos de los fosfolípidos permitiendo su estabilización en las HDL 


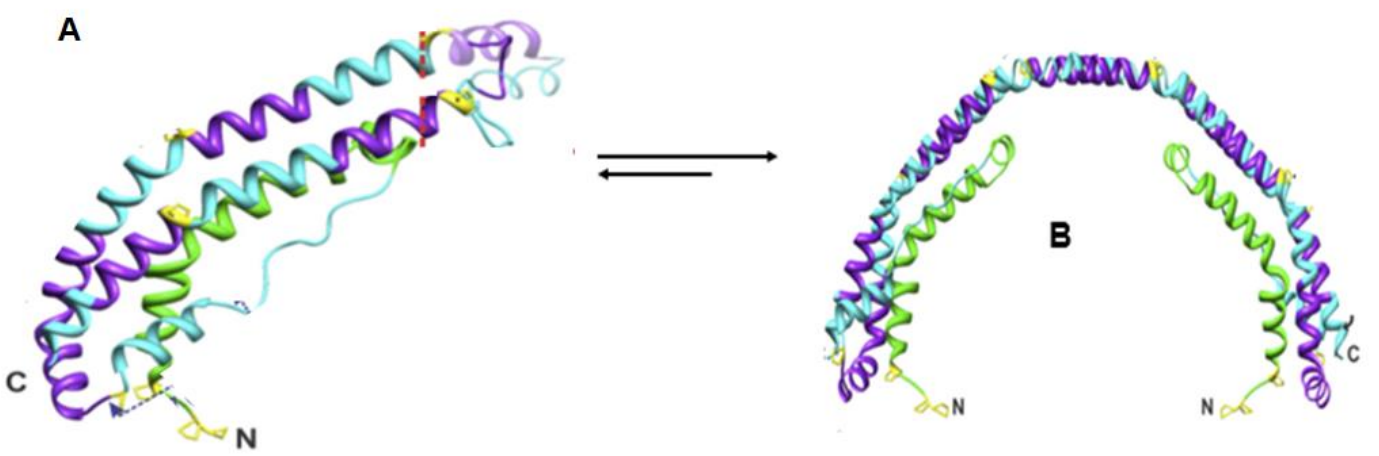

Figura 1.3. Representación de la estructura de ApoA-I $\Delta$ (185-243) según el PDB 3R2P (Protein Data Bank) A) Monómero. B) Dímero (Mei X 2011).

Los monómeros que forman parte de la ApoA-I se encuentran estabilizados principalmente por interacciones $\pi$-catión generadas por aminoácidos básicos como R y K (Arginina y Lisina en la nomenclatura de una letra para aminoácidos, la que seguirá siendo utilizada en este trabajo), que aportan una carga positiva, con aminoácidos aromáticos como $\mathrm{W}$ aportando a la interacción una nube electrónica " $\Pi$ "; las más importantes son: W8-R61 y W50 K23 (recuadros A y D respectivamente en la Figura 1.4) (Mei X 2011). En el dímero se propone que la estabilización puede deberse a una zona denominada haz de hélices formado por el extremo N-de una molécula y el C- de la otra (Gursky O 2012, Mei X 2011). Las interacciones más importantes que estabilizan esta conformación serían dos "clústers" hidrofóbicos (Figura 1.4) en el haz de hélice en la zona baja (panel B) y alta (panel C) formados por aminoácidos alifáticos y aromáticos (Gursky O 2012) Bajo: F71, W72, W8, L14, L60, L64, L75 con L170, L174, L178 y L181 de la segunda molécula. Alto: F33, F104, W108, V30, L38, L42, L44, V156 y L159 de la segunda. 


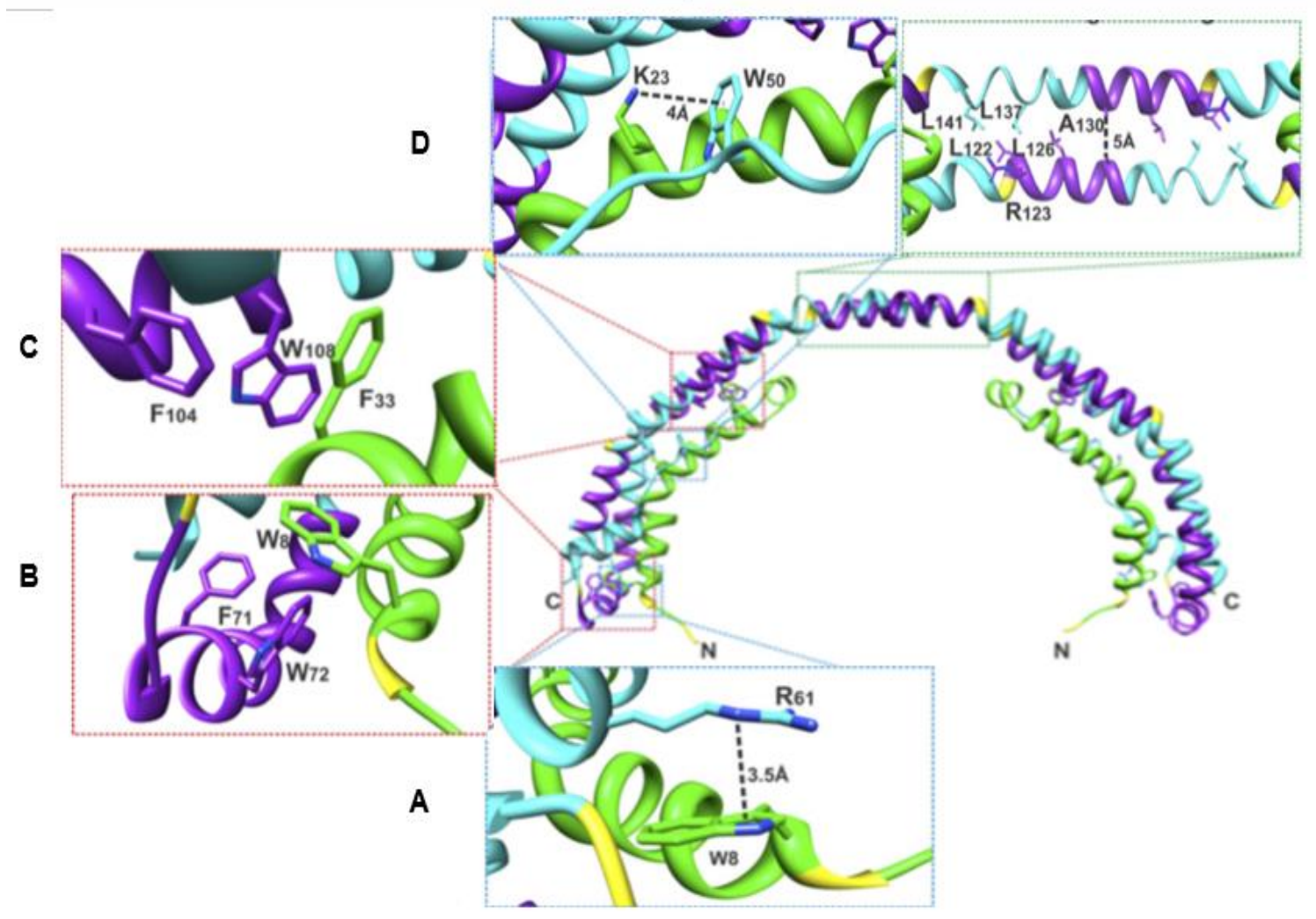

Figura 1.4. Interacciones propuestas que estabilizan la ApoA-I. Dimero A) y D) Interacción T- catión entre monómeros B) Clúster hidrofóbico zona baja del haz de hélice, C) Clúster hidrofóbico zona alta del haz de hélice (Mei X 2011).

Además de estas interacciones se propone que el haz de hélice se estabiliza por puentes salinos entre aminoácidos cargados entre los monómeros de ApoA-l; ocurren entre un residuo (i) y otro que se encuentra a una distancia de 3 o bien de 4 aminoácidos del $\mathrm{i}$; donde estas últimas son de mayor magnitud respecto a las anteriores, las más importantes son K96-E169 (i-i+3) D 89- R173E92 y E85-R177-D89 (i,i+4) (Mei X 2011, Shih A 2009).

\subsection{FUNCIÓN DE LA APOLIPOPROTEÍNA A-I}

Una de las funciones principales de la proteína es la de participar del TRC. En su estado libre de lípidos es más eficiente para interaccionar con el receptor de membrana plasmática ATP binding cassette (ABCA1) y promover la salida de colesterol (col) de los tejidos extra hepáticos, dando lugar a la formación de HDL 
discoidales ( $d H D L)$, que se componen mayoritariamente de col libre y fosfolípidos (PL). La ApoA-I es el cofactor del enzima lecitin colesterol acil transferasa (LCAT) que cataliza la síntesis de ésteres de colesterol (EC) (Bibow S 2016); para que la LCAT se encuentre activa es necesaria la interacción con la hélice 6 de la ApoA-I. La naturaleza hidrofóbica de los EC promueve la formación de un núcleo central en estas lipoproteínas, generando como consecuencia de un proceso complejo las HDL esféricas maduras. En el hígado esta HDL interactúa en un proceso mediado por ApoA-I con el receptor Scavenger B1, promoviendo la extracción de los EC y su lipólisis a col libre con la posterior síntesis de sales biliares, y otros derivados, como por ejemplo hormonas esteroideas. Este proceso favorece su eliminación de circulación (Del Guidice R 2017, Xu B 2017). La Figura 1.5 resume estos eventos.
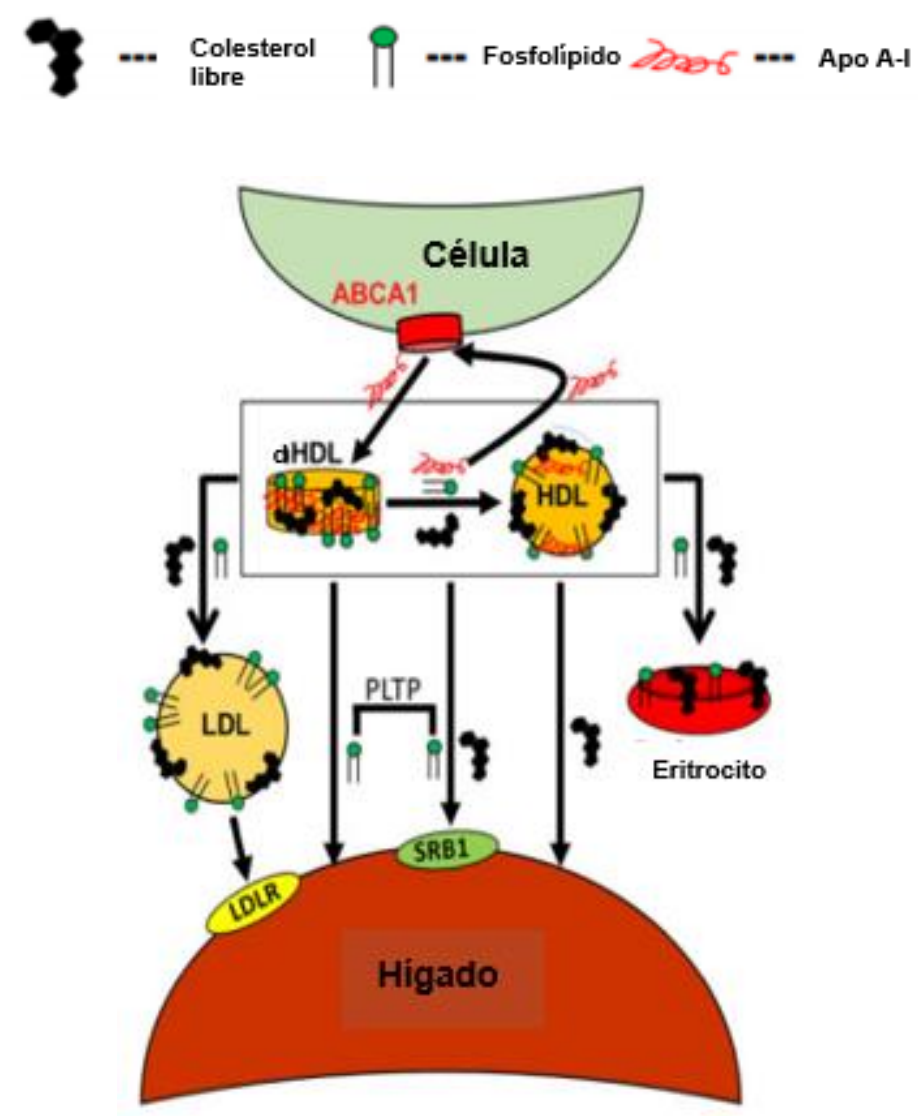
Figura 1.5. Modelo remodelación de dHDL. La ApoA-I libre interactúa con el trasportador ABCA1 en la membrana celular activando la remoción de col libre y PL, rindiendo dHDL; en circulación la LCAT cataliza la esterificación de col, favoreciendo la formación de las HDL esféricas maduras. HDL interactúa con hepatocitos mediante receptores SRB1 activando su eliminación de circulación. Los eritrocitos permiten almacenar PL y col para contribuir a la maduración de HDL, mientras que LDL puede interactuar con su receptor hepático para permitir la captación de col y otros lípidos (Xu B 2017).

La unión de ApoA-I con los receptores ABCA1 induce activación de numerosas vías metabólicas como proteínas kinasas $A$ y $C$ que potencian al TRC debido a la estabilidad y aumento de la transcripción del gen de ABCA1 (Zhao GJ 2012).

En una función no menos importante la ApoA-I asociada a HDL presenta una función anti inflamatoria debido a la participación en numerosas vías, entre ellas la inhibición de la oxidación de LDL (LDLox), dada por el quimoatractante MCP-1, que es liberado por macrófagos activos. De no ocurrir esta inhibición es más factible la peroxidación lipídica y el incremento de especies reactivas del oxígeno, junto con un aumento de los niveles de IL-1 $\beta$ y TNF $\alpha$ (Namiri-Kalantari $R$ 2015). La participación de secuencias de la proteína involucradas en esta función se puso de manifiesto mediante el uso de péptidos miméticos de ApoA-I como 4F, los que bloquean vías pro inflamatorias (McGrath K 2020).

\subsection{APOLIPOPROTEINA A-I Y AMILOIDOSIS}

Hasta el momento han sido descriptas más de 50 variantes naturales de ApoA-I. Aproximadamente la mitad de las mismas inducen en pacientes niveles de HDL en sangre disminuidos (Obici L 2006), y otras 20 se encuentran involucradas en amiloidosis hereditarias (Arciello A 2016, Rowczenio D 2011). En este caso las mutaciones puntuales más frecuentes son sustituciones de aminoácidos neutros por residuos básicos como Arginina aunque se han detectado otras de distinta naturaleza (Obici L 2006). Eriksson y colaboradores han descripto dos regiones clave en las que ocurre la mayoría de las mutaciones amiloidogénicas. La primer región abarca a los residuos entre el 26-93 de la secuencia nativa, y los depósitos proteicos de ApoA-I se encuentran involucrados en el desarrollo de amiloidosis renal y hepática (Eriksson M 2009); 
La segunda región comprende los aminoácidos entre el 173 y 178, y en cambio estas mutaciones se asocian a amiloidosis cardiaca, laríngea y cutánea principalmente (Eriksson M 2009, Rowczenio D 2011). La Figura 1.6 muestra la localización de dichas mutaciones en la secuencia extendida y en la Tabla 1 se detallan algunas de las mutaciones descriptas

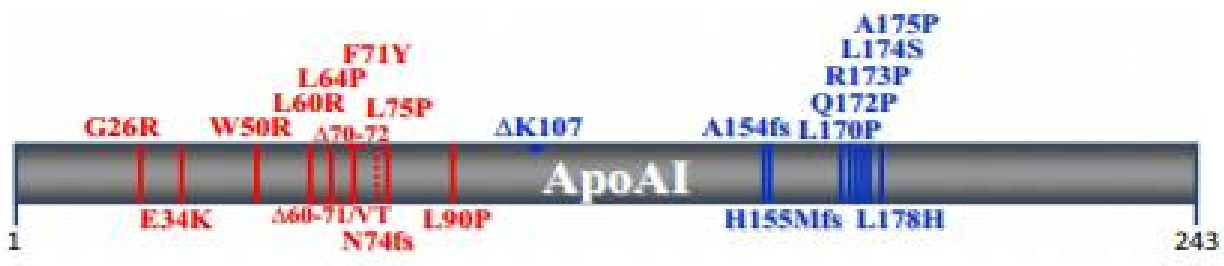

Figura 1.6. Variantes naturales de ApoA-I asociadas a amiloidosis. En rojo mutantes del extremo N- y en azul mutantes asociadas al extremo C- (Arciello A 2016)

Tabla 1.1. Algunas de las Variantes naturales de ApoA-I estudiadas en mayor detalle (Tougaard BG 2016).

\begin{tabular}{|c|c|c|c|}
\hline VARIANTEE & ORGANO & DEPOSITOS & CLINICA \\
\hline & ESPECIFIC|DAD & AMILOIDES & \\
\hline $\begin{array}{l}\text { G26R (Van Allen, } \\
\text { 1969) }\end{array}$ & $\begin{array}{l}\text { Nervios periféricos, } \\
\text { riñón, hígado }\end{array}$ & $\begin{array}{l}\text { Sistema nervioso, } \\
\text { intersticio renal(IR) }\end{array}$ & $\begin{array}{l}\text { Poli neuropatia amiloide } \\
\text { familiar (PAF) } \\
\text { Enfermedad renal } \\
\text { crónica(ERC) }\end{array}$ \\
\hline G34R & Higado, riñón, & IR & ERC \\
\hline W50R (Booth, 1995) & Higado, riñón & IR y glomérulo & ERC \\
\hline L60R (Soutar, 1992) & $\begin{array}{l}\text { Hígado, riñón, } \\
\text { testículo }\end{array}$ & IR & ERC \\
\hline L64P & Hígado, riñón, bazo & IR y glomérulo & ERC \\
\hline L75P & Higado, riñón, bazo & IR y glomérulo & ERC \\
\hline$\Delta K 107-0$ & Túnica aortica & Aorta & Enfermedad coronaria \\
\hline R173P(Hamidi,1999) & $\begin{array}{l}\text { Corazón, laringe, } \\
\text { piel }\end{array}$ & Corazón & Cardiomiopatia \\
\hline L178H & $\begin{array}{l}\text { Corazón, laringe, } \\
\text { piel }\end{array}$ & Corazón & Cardiomiopatía \\
\hline
\end{tabular}

En la actualidad, mediante el software AMYLPRED se han predicho regiones de ApoA-I que al sufrir mutaciones puedan generar variantes pro amiloides. Dichas regiones son las siguientes: 14-22 (LATVYVDVL), 53-58 (VTSTFS), 69-72 (QEFW) y 227-232 (VSFLSA) (Figura 1.7) (Das M 2014). 


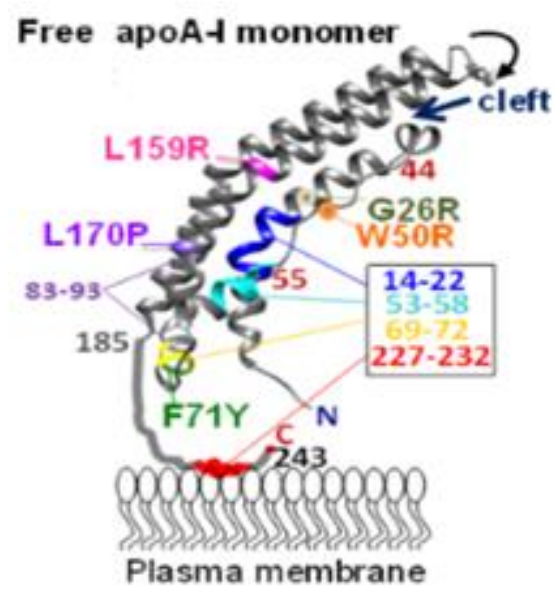

Figura 1.7. Puntos clave de mutación de ApoA-I. Modelo representativo del monómero de la ApoA-I C-terminal truncada, mostrando mutaciones naturales y en el recuadro los segmentos pro amiloidogénicos predichos por el software Amylpred (Das M 2014)

A fin de echar luz sobre los eventos que pudieran inducir la agregación y la toxicidad de las variantes de ApoA-I se realizaron previamente en nuestro laboratorio distintos estudios que dan base a los propuestos en este trabajo. Entre otros se estudiaron tres mutantes naturales de la proteína: una mutante de substitución, G26R, asociada a amiloidosis con polineuropatía (Van Allen MW 1969), la mutante de deleción (K107-0) donde la amiloidosis induce aterosclerosis severa (Mucchiano GI 2001), y una variante con sustitución R173P que genera amiloidosis cardíaca, cutánea y laríngea (Hamidi AK 1999). Los resultados mostraron que las variantes comparten parámetros estructurales similares, como mayor inestabilidad y una estructura más flexible que la proteína $\mathrm{Wt}$, dando lugar a estados parcialmente desplegados. Sin embargo, de manera interesante, eventos diferentes parecieran dar lugar a la patogenicidad de las mismas. Así, se observó que K107-0 mostró una mayor tendencia a formar estructuras amiloides que la proteína $\mathrm{Wt}$ a $\mathrm{pH}$ fisiológico, y fue más susceptible que la variante $G 26 R$ a agregarse en un ambiente pro-inflamatorio inducido por neutrófilos activados in vitro. En cambio, y dando sustento a esta presentación, la variante G26R indujo en su estado monomérico, la liberación de IL-1 $\beta$ y de TNF- $\alpha$ de monocitos en cultivo (Ramella NA 2012). Estos estudios fueron profundizados posteriormente, encontrando que la liberación de dichas citoquinas involucra el aumento de la producción de prostaglandina E2, óxido nítrico y la translocación del factor NF-kß al núcleo (Ramella NA 2018). La 
importancia de estos datos radica en que podrían sugerir que estructuras previas al estado fibrilar de la ApoA-I podrían ser citotóxicas, como fue descripto para estructuras oligoméricas, principalmente en la enfermedad de Alzheimer y en la amiloidosis asociadas a Transtirretina (Reixach N 2004)

\subsection{AMILOIDOSIS RENAL POR APOLIPOPROTEINA A-I}

Como fue mencionado, un órgano blanco prevalente en amiloidosis debido a ApoA-I es el riñón, en especial cuando la mutación abarca el extremo $\mathrm{N}$ de la molécula. A diferencia de lo que ocurre con otras amiloidosis renales (que ocurren preferentemente en glomérulo), las variantes de ApoA-I se depositan preferentemente a nivel túbulo intersticial. Una excepción lo constituye la variante W50R que ha sido hallada tanto en corteza como en médula (Lu C 2017). En la Figura 1.8 se pueden visualizar lesiones amiloides en pacientes mediante la técnica de Rojo Congo.

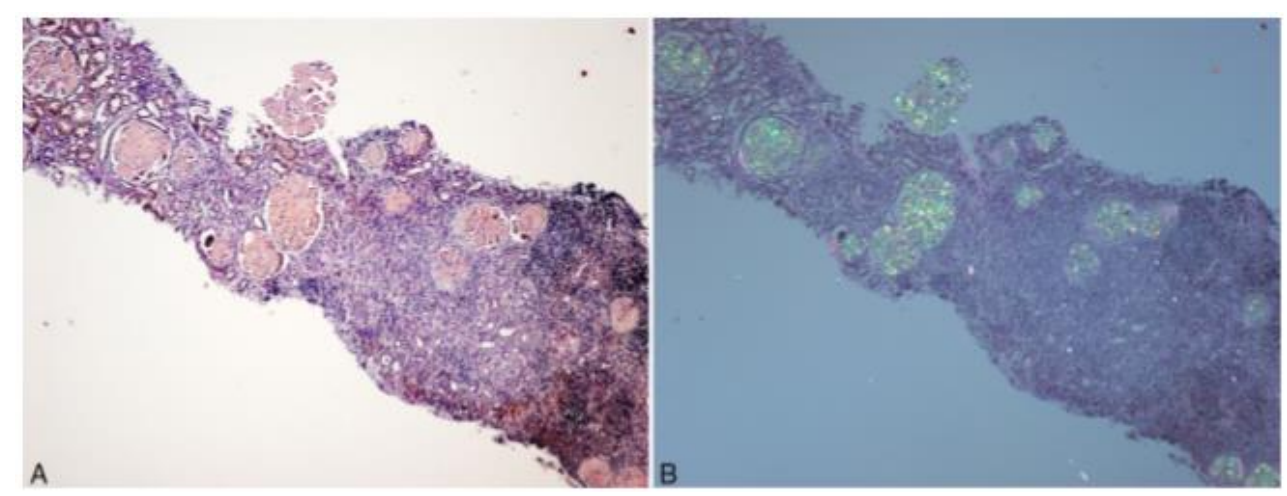

Figura 1.8. Biopsia de corteza renal donde se observan los depósitos amiloides de la variante W50R A) Tinción hematoxilina- eosina. En rosado se observan los depósitos amiloides que ocupan gran parte del parénquima renal; B) Tinción con rojo congo y observada bajo luz polarizada. Los depósitos amiloides son confirmados por la birrefringencia color verde manzana (Samillan-Sosa KDR 2015)

El cuadro clínico asociado es complejo y de acuerdo a la localización glomerular o túbulo intersticial puede variar: el primero se caracteriza por proteinuria, descenso de la velocidad de filtración glomerular (VFG) y 
glomerulonefritis; en el segundo caso en cambio presenta desorden en el transporte tubular, acidosis tubular renal y nefritis túbulo intersticial (SamillanSosa KDR 2015, Kidd J 2016, Gregorini G 2005, Gregorini G 2015). Todos estos signos y síntomas llevan a un cuadro de enfermedad renal con una respuesta inflamatoria crónica (ERC). A medida que va disminuyendo la VFG y el daño en el parénquima renal ya es irreversible se ingresa a la enfermedad con cuadro renal terminal (ERT) (Gregorini G 2005, Gregorini G 2015), que culmina con el trasplante del órgano como único tratamiento posible. En la actualidad, normalmente se arriba al diagnóstico en estadios avanzados, y luego de descartar otras patologías. Todo ello produce como consecuencia la demora en el tratamiento paliativo de las consecuencias de estas patologías desbastadoras.

\subsection{RESPUESTA INFLAMATORIA ASOCIADA A ENFERMEDADES RENALES CRÓNICAS}

La incidencia de procesos pro inflamatorios en la evolución de diversas patologías crónicas es un campo de extenso y actual estudio, ya que permitiría no sólo la identificación de factores catalizadores en el establecimiento del cuadro clínico, sino además haría esperable la determinación de terapias paliativas.

El riñón es uno del principales órgano blanco en la activación no provocada de vías del sistema inmune, y la presencia de lesiones normalmente incluye la secreción de IL-1 $\beta$ y IL-18. La proteína reactante de fase aguda SAA (amiloide sérico) como depósitos amiloides culmina con progresivo daño glomerular y vascular.

La ERC y ERT dada por un proceso inflamatorio crónico lleva a una injuria tisular y disminución de la función renal. Una consecuencia de este fenómeno es la presencia de patrones moleculares asociados a daño (DAMPs) en el riñón. Los DAMPs pueden ser de diversos orígenes (Rojo-León V 2012, Hutton HL 2016, Scarpioni R 2018):

- Liberados por las células de un tejido mediante diversos mediadores de muerte, como el ácido úrico. 
- Ser derivados de fragmentos generados de la degradación de la matriz extracelular, lo que puede ocurrir en la inflamación crónica.

- Pueden ser moléculas de origen endógeno reconocidos por el sistema inmune, como el péptido $\beta$ amiloide

Dada su implicancia en la patogénesis de una serie de afecciones renales (como lesión renal aguda, enfermedad renal crónica, nefropatía diabética y nefropatía relacionada con cristales), un mecanismo probable de daño a considerar es la activación del llamado inflamosoma NLRP3 (nucleotide-binding oligomerisation domain, leucine-rich repeat and pyrin domain containing 3). Los inflamasomas son componentes del sistema inmune innato que responden al estrés celular produciendo citoquinas pro inflamatorias como la IL-1 $\beta$. Están constituidos por plataformas intracelulares que convierten citoquinas pro inflamatorias en sus formas activas en respuesta a "señales de peligro". La activación del inflamasoma NLRP3 requiere dos señales (Figura 1.9).

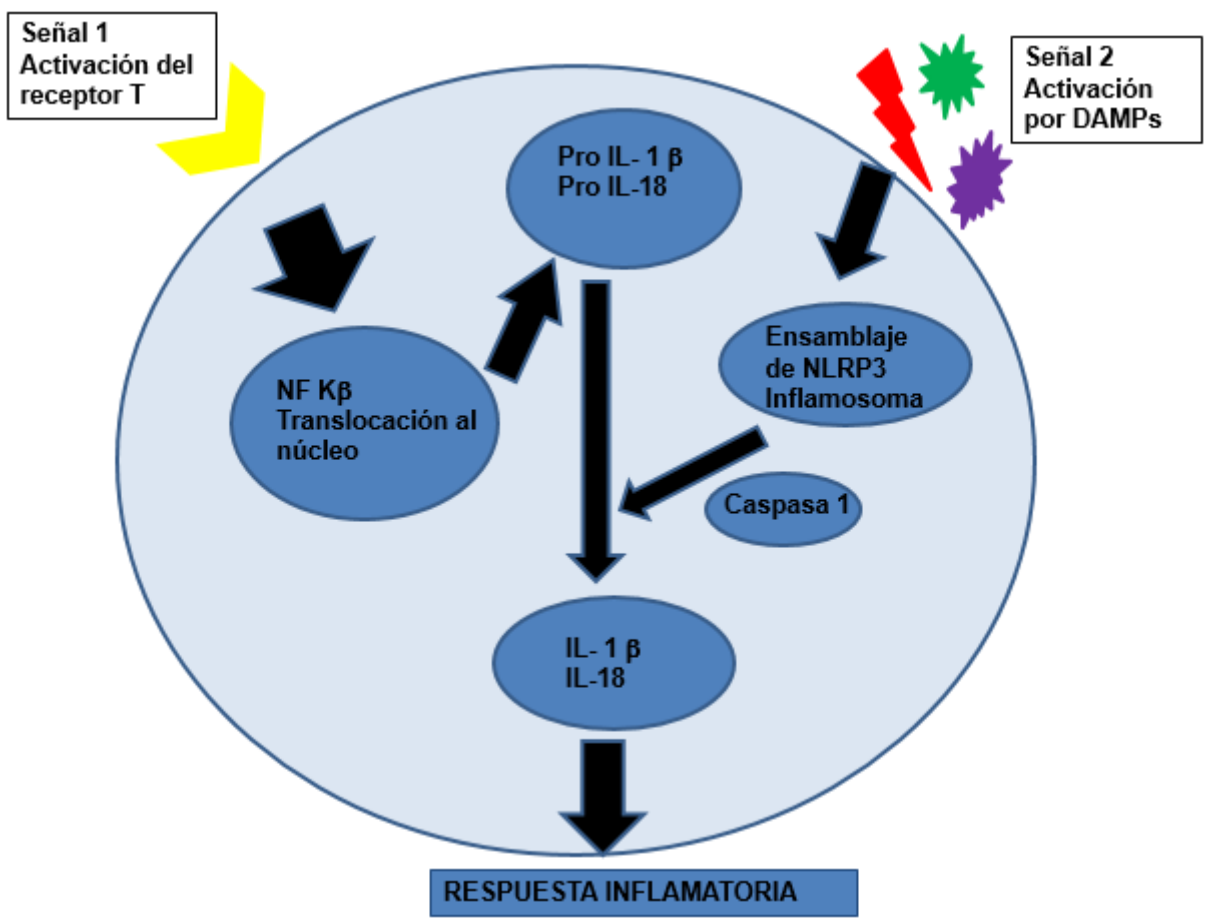

Figura 1.9: esquema de activación del inflamosoma NLRP3. La activación puede deberse a diversos DAMPs, entre los que podría considerarse a proteínas mal plegadas 
El paso inicial implica a menudo la activación de receptores transmembrana como los receptores tipo Toll (TLR), desencadenando la transcripción del gen dependiente de NF-k $\beta$ de pro-IL-1 $\beta$ y pro-IL-18. Estas citoquinas pro inflamatorias se liberan en el citoplasma como pro-IL-1 $\beta$ y pro-IL18 y requieren escisión, generalmente por caspasas, para activarse y secretarse. El ensamblaje del complejo inflamatorio NLRP3-ASC (pro caspasa) ocurre a través de un segunda señal, que hace que NLRP3 se oligomerice y reclute ASC, activando la caspasa 1 y finalmente resultando en la escisión y secreción de las citoquinas pro inflamatorias. De manera interesante, distintos estímulos podrán activar este sistema, lo que abre un campo inmenso a fin de reconocer la probable participación de éste y otros sistemas. En amiloidosis estas vías son altamente interesantes de indagar, ya que ha sido descripta la participación del NLRP3 en la activación de macrófagos por estados fibrilares de proteínas amiloides.

De los resultados previos del grupo, es esperable que alguna o algunas de las conformaciones de ApoA-I y sus variantes puedan activar a protagonistas de la inmunidad innata. Estos resultados previos demostraron que el mutante G26R indujo la liberación de IL-1 $\beta$ y TNF- $\alpha$ de un modelo de macrófagos murinos (Ramella NA 2012), lo que resultó en la translocación del NFk- $\beta$ al núcleo (Ramella NA 2018). Estos resultados dan el puntapié inicial y conducen a profundizar el estudio de las vías de señalización que puedan estar participando.

\section{HIPÓTESIS DEL TRABAJO}

En base a los estudios previos mencionados se disparan numerosos interrogantes, cuya respuesta permita establecer las bases de la amiloidosis debida a mutantes N-terminales de ApoA-I. Dada la incidencia crítica de la patología renal, y el patrón característico de agregación, nos proponemos profundizar el conocimiento de las causas que puedan determinar la agregación patológica y la aparente diferencia en el patrón de agregación. Propongo extender los conocimientos en cuanto a sus características estructurales, tendencia a la agregación en presencia o ausencia de ligandos celulares, susceptibilidad a la proteólisis y comparar esta información con la obtenida de la 
secuencia nativa. Considero también importante testear el probable inicio de respuesta inflamatoria inducido por la presencia de mutaciones. Para tal fin, elegimos estudiar comparativamente dos variantes: W50R y L60R, ya que son cercanas en la secuencia en la región $\mathrm{N}$-terminal, poseen un reemplazo similar en la naturaleza de un aminoácido pero inducen en pacientes diferente localización de las lesiones amiloides a nivel renal.

Nos proponemos responder las siguientes hipótesis:

A. Las mutaciones W50R y L60R, en el extremo $N$ de ApoA-I, inducen pequeñas perturbaciones estructurales que rinden una conformación pro amiloidogénica.

B. Los ligandos celulares como glucosaminoglucanos presentes en la matriz extracelular y algunos lípidos negativos se unen a las mutantes W50R y L60R incrementando su tendencia a la agregación.

C. Las variantes mencionadas son más susceptibles que la proteína nativa a la proteólisis.

D. W50R y L60R inducen la activación de la respuesta inmune en el modelo de macrófagos THP-1.

\section{OBJETIVOS}

OBJETIVO GENERAL

El objetivo general de esta tesis es el conocer los determinantes estructurales que desencadenan los mecanismos patológicos de la amiloidosis renal inducida por las variantes naturales de ApoA-I.

\section{OBJETIVOS ESPECÍFICOS}

- Construir dos variantes naturales de ApoA-I con substitución en el extremo N: W50R y L60R mediante técnicas de biología molecular.

- Caracterizar estructuralmente las variantes mencionadas en relación a la proteína con la secuencia nativa $(\mathrm{Wt})$. 
- Analizar la tendencia a la agregación de las mutantes frente a probables alteraciones en el micro entorno (descenso de $\mathrm{pH}$ y urea), y en presencia de ligandos celulares como glucosaminoglucanos y lípidos negativos

- Indagar en la sensibilidad de las variantes ante un procesamiento proteolítico.

- Determinar si las mismas variantes puedan activar una respuesta inmune en un modelo celular.

\section{MATERIALES Y MÉTODOS}

\subsection{MATERIALES.}

Los materiales empleados fueron los de mayor grado de pureza disponible. Los proveedores de los más utilizados se detallan a continuación: de Sigma-Aldrich (St Louis, MO, EeUu): ester de forbol (PMA), hidroximetil aminometano clorhídrico (Tris) tripsina, guanidina clorhídrica ( $\mathrm{GdnHCl})$, dodecil sulfato de sodio (SDS), acrilamida, bis acrilamida, TEMED, tioflavina T (ThT), polimixina B, lipopolisacárido bacteriano (LPS), luminol, ácido cumárico. De Avanti Polar Lipids (Alabaster, $\mathrm{AL}$ ): dimiristoil sn-glicerol-3-fosfatidilcolina (DMPC); De GE Health Care Bio-Sciences AB, Uppsala, Suecia: resina de Sepharosa 6 fast flow (IMAC). De Invitrogen (Carlsbad, CA, EeUu): ácido 4 ,4'dianilino-1,1'-binaftilo- 5,5'- disulfónico bipotásico (Bis-ANS). De Thermo Scientific (Waltham, MA, EeUu): Isopropil- $\beta$-D-tiogalactósido (IPTG). De Biopack (Bs As, Arg): cloruro de sodio ( $\mathrm{NaCl}$ ), Coomassie blue R250 y G250, ácido fosfórico, ácido sulfúrico, ácido clorhídrico. De Carlo Erba (Bs As, Arg): ácido acético, alcohol etílico, carbonato de sodio, ácido fórmico, formol, nitrato de plata. De Brittania (Bs As, Arg): tripteína y extracto de levadura.

\subsection{MÉTODOS}

4.2.1. CONSTRUCCIÓN DE LAS VARIANTES DE APOA-I: W5OR y L60R 
A fin de obtener ApoA-I y sus variantes con alto rendimiento y grado de pureza se utilizó el vector de expresión pET 30a (+) (Figura 4.1, Novagen, Madison, WI, EeUu). Este vector posee un gen de resistencia a la kanamicina y un promotor inducible por IPTG, el que se encuentra "previo" a una secuencia que codifica para un péptido rico en residuos histidinas (His-tag) y que permitirá posteriormente la purificación eficiente de las variantes. A continuación de este péptido fue clonado el cDNA correspondiente a la ApoA-I humana con la secuencia nativa (cedido por la Dra. A. Jonas, University of Illinois at UrbanaChampaign, IL, EeUu). Empleando el kit de mutagénesis dirigida (Stratagen, La Jolla, CA) se sustituyó el segundo amino ácido (ácido glutámico, E) por ácido aspártico $(D)$ a fin de introducir un sitio D-P lábil para proteólisis mediante ácido fórmico entre los aminoácidos 2 y 3 de la ApoA-I (Ryan RO 2003). Este procedimiento permitió el clivaje de manera eficiente y específica entre la proteína y el péptido de fusión His-tag ubicado en el extremo N-. En estudios previos del grupo se demostró que la proteína obtenida de esta manera se comportó indistinguible a la ApoA-I plasmática (Prieto ED 2012)

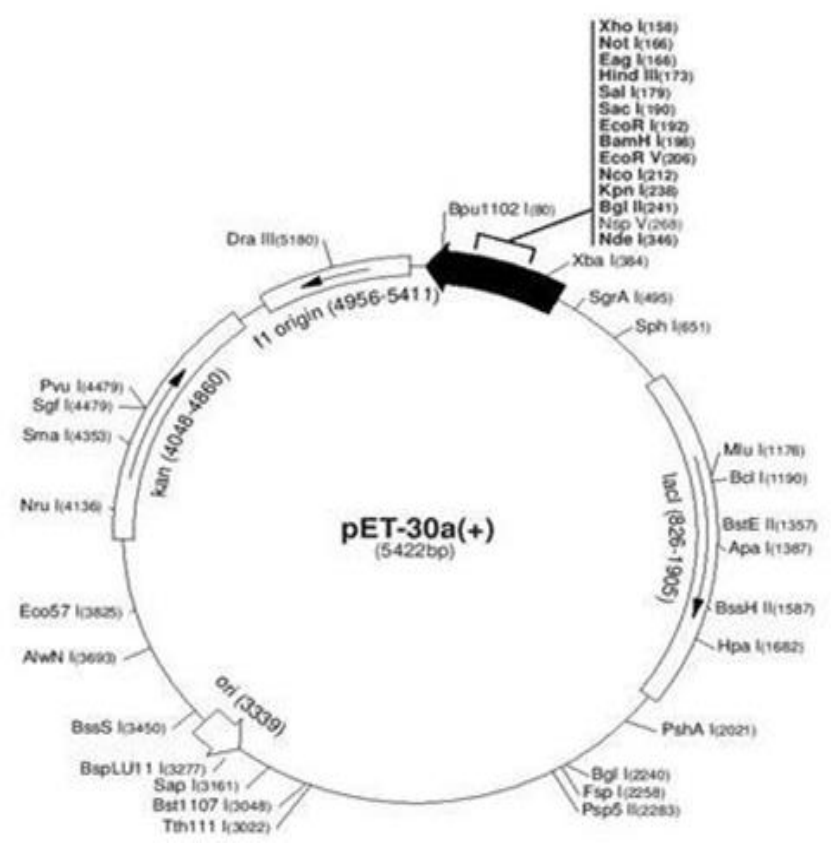

Figura 4.2.1. Mapa del vector $\mathrm{pET} 30 \mathrm{a}(+)$

Las variantes W50R y L60R fueron construidas mediante mutagénesis dirigida por PCR con el kit Quick Change (Stratagene), usando como molde el 
plásmido conteniendo el gen de la ApoA-I con la secuencia nativa (Wt); se diseñaron los primers específicos para obtener cada variante:

W50R

Sense 5'-agctccttgacaacagggacagcgtgacc-3'

Antisense 5'-ggtcacgctgtccctgttgtcaaggagct-3'

L60R

Sense 5'-caccttcagcaagcggcgcgaacagctcg-3'

Antisense 5'-cgagctgttcgcgccgcttgctgaaggtg-3'

El programa del termociclador (GeneAmp PCR System 2400) para realizar la PCR fue el indicado en la Tabla 4.1:

Tabla 4.1 Programa de condiciones para la amplificación mediante PCR

\begin{tabular}{|c|c|c|}
\hline Ciclos & Temperatura $\left({ }^{\circ} \mathrm{C}\right)$ & Tiempo (min) \\
\hline 1 & 95 & 1 \\
18 & 95 & 1 \\
& 55 & 10 \\
1 & 68 & 10 \\
\hline
\end{tabular}


Una vez terminada la reacción, el rendimiento de la misma fue chequeado por gel de agarosa revelado con bromuro de etidio bajo la luz UV. La presencia de una banda intensa en el plásmido linearizado indica el éxito de la amplificación (Figura 4.3.2).

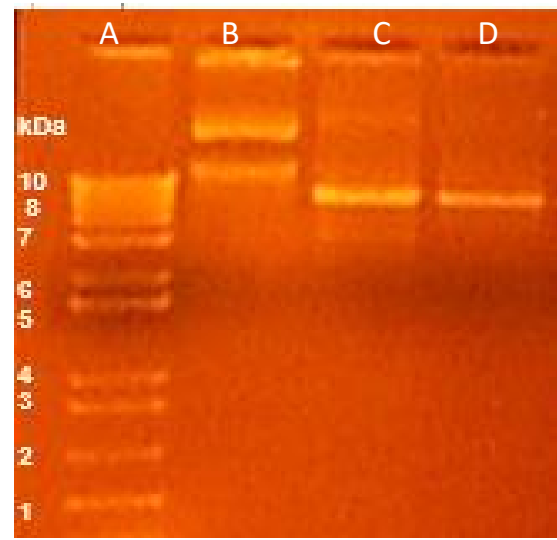

Figura 4.2.2. Productos de PCR. Gel de agarosa al $10 \%$ revelado con bromuro de etidio y observado bajo lámpara UV. Las calles a continuación son las siguientes: A) Biomarker ladder 1kb; B) Plásmido pET 30+ sin linearizar (bandas de "coiled" y "super coiled"); C) y D) Productos de amplificación utilizando primer para W50R y L60R respectivamente.

Los productos de PCR fueron sometidos a la acción de la endonucleasa DNP I a $37^{\circ} \mathrm{C}$ durante $1 \mathrm{~h}$ para eliminar el ADN molde utilizado en la PCR, ya que este enzima digiere selectivamente el ADN metilado. Se procedió a la electro transformación de bacterias E. coli BL 21 electro competentes, las cuales fueron sometidas a la acción de un campo eléctrico externo con el fin de aumentar la permeabilidad de la membrana e incorporar el producto de PCR; se incubaron 1 $\mathrm{h}$ a $37^{\circ} \mathrm{C}$ y luego se plaquearon en agar con LB más kanamicina en una concentración final de $50 \mu \mathrm{g} / \mathrm{ml}$. Las placas se crecieron toda la noche (ON) a $37{ }^{\circ} \mathrm{C}$. Se sembró una de las colonias crecidas (selección positiva por la resistencia a kanamicina) en medio LB+kan y se incubó ON. Se extrajo el ADN plasmídico mediante un kit comercial de mini prep (Qiagen); posteriormente se procedió a la concentración del material genético empleando evaporación al vacío por Speed Vac (Variant) y se cuantificó mediante lectura de absorbancia (DO) a $260 \mathrm{~nm}$ mediante el micro espectrofotómetro Nano Drop 
2000 (Beckman); por último, la secuenciación del ADN se llevó a cabo en Macrogen (Corea del sur) deseadas. Una vez confirmadas las mutaciones deseadas, se chequeó en las colonias seleccionadas la expresión de las variantes de ApoA-I. Con tal fin se crecieron las colonias en LB+kan durante $5 \mathrm{~h}$ y luego se agregó IPTG, dejando en agitación por $2 \mathrm{~h}$. Se chequeó la expresión por electroforesis en gel de poliacrilamida con SDS (SDS PAGE) al $14 \%$ teñido con Coomassie Blue. Confirmada la expresión de las colonias, éstas se expandieron en medio LB+kan en agitación constante $\mathrm{ON}$; luego se guardaron stocks de bacterias en glicerol al $20 \%$ a $-70{ }^{\circ} \mathrm{C}$ hasta su posterior uso.

\subsubsection{EXPRESIÓN DE VARIANTES DE APOA-I}

Se prepararon $5 \mathrm{ml}$ de medio LB+kan en el cual se agregaron en condición de esterilidad bacterias del stock y se dejó creciendo a $37{ }^{\circ} \mathrm{C}$ ON en agitación constante; luego se inocularon $2 \mathrm{ml}$ de este medio en $500 \mathrm{ml}$ de LB+kan y se incubó a $200 \mathrm{rpm}$ y $37^{\circ} \mathrm{C}$ hasta alcanzar una DO de 0.5 a $600 \mathrm{~nm}$. La expresión de ApoA-I se indujo con IPTG $(0.4 \mathrm{mM})$ durante $2 \mathrm{~h}$ a $37^{\circ} \mathrm{C}$. Las bacterias se cosecharon por centrifugación durante $10 \mathrm{~min}$ a $6000 \mathrm{rpm}$ y $4{ }^{\circ} \mathrm{C}$. Los pellets fueron reservados a $-20^{\circ} \mathrm{C}$ hasta su uso.

\subsubsection{PURIFICACIÓN DE VARIANTES NATURALES DE APOA-I}

Los pellets de bacterias fueron resuspendidos en una solución de guanidina clorhídrica $(\mathrm{GndHCl}) 6 \mathrm{M}$ y NaCl $150 \mathrm{mM}$ con agitación suave y constante durante $4 \mathrm{~h}$ a $4{ }^{\circ} \mathrm{C}$; luego se centrifugó a $10000 \mathrm{rpm}$ durante $15 \mathrm{~min}$ y el sobrenadante fue dializado exhaustivamente con buffer Tris $20 \mathrm{mM}$ y $150 \mathrm{mM}$ $\mathrm{NaCl} \mathrm{pH} 8.0$ a $4^{\circ} \mathrm{C}$. Posterior a una nueva centrifugación, la purificación se llevó a cabo en una columna de afinidad cargada con $\mathrm{Ni}_{2} \mathrm{SO}_{4}$ IMAC Sepharose

6 fast flow, que retiene con elevada afinidad al péptido poli His. Luego de lavados exhaustivos la proteína de fusión fue eluida mediante competencia con un buffer con alto contenido en imidazol (500 mM) (Ryan RO 2003). Se recogieron las 
fracciones de las etapas de la purificación y su pureza fue verificada por electroforesis en SDS PAGE al 14\%. Las fracciones eluidas conteniendo ApoAI fueron tratadas con ácido fórmico al $45 \% \mathrm{v} / \mathrm{v}$ durante $5 \mathrm{~h}$ a $60{ }^{\circ} \mathrm{C}$ para separar la cola de His de la proteína. A continuación se dializó exhaustivamente para eliminar el ácido fórmico. Se realizó una segunda elución para obtener la proteína pura (Prieto ED 2012), y el grado de pureza y rendimiento fue confirmado posteriormente mediante un gel similar al primer paso de purificación. Las proteínas purificadas se guardaron a $-20{ }^{\circ} \mathrm{C}$ en concentración $1 \mathrm{M}$ de $\mathrm{GndHCl}$ para evitar que se agregue hasta su uso; previo a ser utilizadas fueron dializadas exhaustivamente contra buffer Tris $20 \mathrm{mM} \mathrm{pH} 7.4$ (Tris salino) (o en otro buffer de interés) para extracción completa del agente caotrópico; por último, se cuantificaron mediante el método de Bradford (Bradford MM 1976) midiendo absorbancia a $595 \mathrm{~nm}$ en lector de placa (DTX 880, Beckman Merck).

\subsubsection{TÉCNICAS ELECTROFORÉTICAS}

\subsubsection{GELES DE POLIACRILAMIDA}

Este tipo de geles consta en una fase separativa o "stacking" (donde se siembra las proteínas diluidas en el buffer muestra) y una fase resolutiva o "resolving" donde las muestras se separan según la relación carga/masa frente a un campo eléctrico aplicado externamente. Se utilizó de rutina geles al $14 \%$ en condiciones desnaturalizantes para chequear la purificación y se tiñó con la técnica de Coomassie Blue; cuando fue necesario se usó otro porcentaje de acrilamida y otro tipo de tinción como nitrato de plata.

Las soluciones usadas fueron:

- Acrilamida (30\%p/v)/Bis acrilamida (0.8\%) (Buffer de gel siembra: Tris- $\mathrm{HCl} 0.125 \mathrm{M} \mathrm{pH} 6.8$ ) 
- $\quad$ Buffer de gel separador: Tris- $\mathrm{HCl} 0.375 \mathrm{M} \mathrm{pH} 8.8$

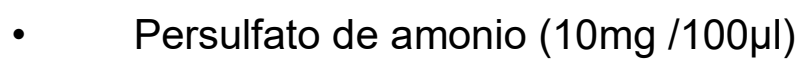

- $\quad$ Catalizador: TEMED

- Buffer de desarrollo: Tris-HCl 0.025 M, - Tris Glicina $0.192 \mathrm{M}, \mathrm{pH}$ 8.3.

- Colorante: Coomassie Blue g-250, $0.1 \%$, en ácido acético $10 \%$ metanol $40 \%$

- Buffer muestra: Tris- $\mathrm{HCl} 0.062 \mathrm{M}$, glicerol $10 \%$, azul de bromo fenol $(0.05 \mathrm{mg} / \mathrm{ml}), \mathrm{pH} 6.8$

- SDS (para llegar a una con concentración final de $0.1 \%$ )

\subsubsection{WESTERN BLOT}

Esta técnica electroforética se basa en la identificación de proteínas mediante el revelado con anticuerpos específicos. El anticuerpo primario policlonal contra ApoA-I fue previamente obtenido en el laboratorio, a partir de inoculación en conejos, y posterior purificación de sangre mediante precipitado salino y posterior elución a través de columnas Hi-Trap (Sigma), a la que se le unió covalentemente ApoA-I (Rosú SA 2017, tesis doctoral). Este anticuerpo demostró alta especificidad. Como anticuerpo secundario se utilizó anti-conejo comercial conjugado con peroxidasa (HRP). Cuando fue necesario las proteínas fueron separadas mediante SDS PAGE. Luego se las transfirió (durante $1 \mathrm{~h}$ a 100 volts) a una membrana de nitrocelulosa empleando un equipo de transferencia en húmedo (Bio Rad) utilizando buffer de transferencia: Tris- $\mathrm{HCl}$ $48 \mathrm{mM}$, glicina $39 \mathrm{mM}$ y metanol al $20 \%$, pH 9.2. Se bloqueó con solución de leche descremada al $3 \%$ durante $2 \mathrm{~h}$ en agitación, seguido de lavados con Tris salino durante $30 \mathrm{~min}$; luego se incubó con el anticuerpo primario en una dilución 1:90000 ON a $4{ }^{\circ} \mathrm{C}$ con lavados posteriores y por último se incubó $2 \mathrm{~h}$ con el anticuerpo secundario en una dilución 1:20000 en agitación lavando con buffer Tris salino.

Para el revelado se prepararon dos soluciones que fueron mezcladas y agregadas a la membrana inmediatamente previo al revelado: A) Luminol 250 $\mathrm{mM}$, ácido p-cumárico $90 \mathrm{mM}$ en DMSO y $1.5 \mathrm{M}$ Tris $\mathrm{pH}$ 8.5. B) $1.5 \mathrm{M}$ Tris $\mathrm{pH}$ 
8.5 y $\mathrm{H}_{2} \mathrm{O}_{2}$ al $30 \%$. Luego se reveló mediante el equipo de luminiscencia Chemidoc, BioRad (Centro Investigaciones Cardiovasculares, Facultad Cs Médicas).

\subsubsection{TÉCNICAS BIOFÍSICAS}

\subsubsection{FLUORESCENCIA}

\section{FUNDAMENTO}

La luminiscencia es un fenómeno en el cual una sustancia puede emitir luz cuando es excitada mediante una perturbación ya sea radiación electromagnética ó reacciones químicas, entre otras. La fotoluminiscencia tiene como fuente energética a la radiación electromagnética. El fenómeno se caracteriza por la absorción de energía en forma de fotones con la posterior emisión de luz dado por electrones que retornan al estado basal. Las sustancias que poseen capacidad fluorescente, poseen por lo general electrones deslocalizados, típicamente en dobles enlaces conjugados. La luminiscencia se divide en Fluorescencia (emisión de $10^{-9}$ a $10^{-6} \mathrm{seg}$ ) y fosforescencia $\left(10^{-3}\right.$ a $10^{-}$ ${ }^{2}$ seg). Estos fenómenos de absorción y emisión de luz se pueden graficar en el tradicional diagrama de Jablonski.

\section{Diagrama de Jablonski}

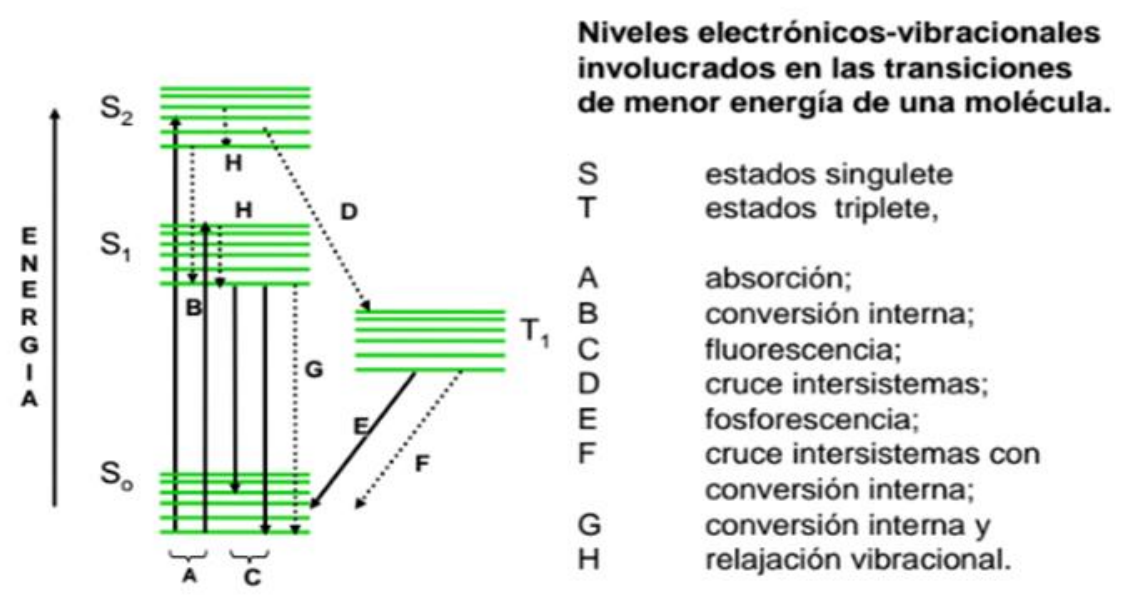

Figura 4.2.3 Diagrama de fluorescencia según Jablonski se visualiza los niveles energéticos junto con la absorción y emisión de energía (Lakowicz JR 2006). 
En el presente diagrama se visualiza los niveles electrónicos basales $S_{0}$ y excitados $S_{1}, S_{2}$, cada uno de ellos presenta un grupo de niveles vibracionales $0,1,2$. Los fotones pueden absorber luz y migrar hacia un estado excitado y desde allí relajarse hacia niveles vibracionales de menor energía, a esto se lo conoce como relajación vibracional. Un fluoróforo puede ser excitado a niveles vibracionales superiores de $S_{1}$ o también a $S_{2}$. Salvo por excepciones, las moléculas suelen relajarse rápidamente a los niveles vibracionales inferiores de $\mathrm{S}_{1}$. Este proceso se llama conversión interna y ocurre en $10^{-12} \mathrm{seg}$.

\section{ESPECTRO DE FLUORESCENCIA}

Los espectros de fluorescencia representan gráficos de intensidad de luz emitida en función de la longitud de onda. La emisión es afectada por diversos factores como la naturaleza química del fluoróforo y del solvente en donde éste se encuentre. Existen dos parámetros espectrales que son especialmente útiles para brindar información sobre la naturaleza de la muestra en la que el fluoróforo se encuentre: intensidad y el corrimiento de la emisión espectral. La primera depende de la concentración de fluoróforo, de la interacción del mismo con su entorno, de la transferencia de energía con la misma especie o con otra, del apagado por otra especie, etc. Todo esto determinará el rendimiento cuántico, 0 sea la relación entre fotones absorbidos versus los emitidos. Al desplazamiento de la longitud de onda entre la absorción y emisión se lo denomina corrimiento de Stokes. Excepto para átomos en fase vapor, de la observación del diagrama de Jablonski se hace evidente que la energía de emisión es típicamente menor que la de absorción, y por lo tanto la fluorescencia ocurre a mayores longitudes de onda que la excitación. La magnitud de este corrimiento generalmente es también sensible al entorno y entonces permite comparar cambios estructurales en proteínas (Lakowicz JR 2006). 
Para el estudio de la estructura proteica es de amplia utilidad el empleo de fluoróforos sintéticos como Bis-ANS, pero especialmente es crítico el análisis de la fluorescencia intrínseca, determinada por los aminoácidos aromáticos triptofano $(W)$, tirosina $(Y)$ y fenilalanina $(F)$. El grupo indol del $W$ es el predominante cuando las proteínas absorben y emiten luz en la región ultravioleta del espectro y su emisión específica puede seleccionarse eligiendo la longitud de onda de excitación (295 nm) (Figura 4.2.4 A). La Y también absorbe en el UV pero su máximo de emisión está dado en longitudes de onda menores que la de éste y su fluorescencia puede ser modificada por interacciones con péptidos o aminoácidos desnaturalizados debido al cambio de pKa del grupo fenol que favorecerían al estado excitado. La emisión del W es muy sensible a su entorno, lo que redunda por ejemplo en corrimiento del espectro hacia el rojo cuando es expuesto al medio acuoso. El máximo de emisión en proteínas está característicamente comprendido entre 330-350 nm (Figura 4.3.4 B) (Lakowicz 2006).
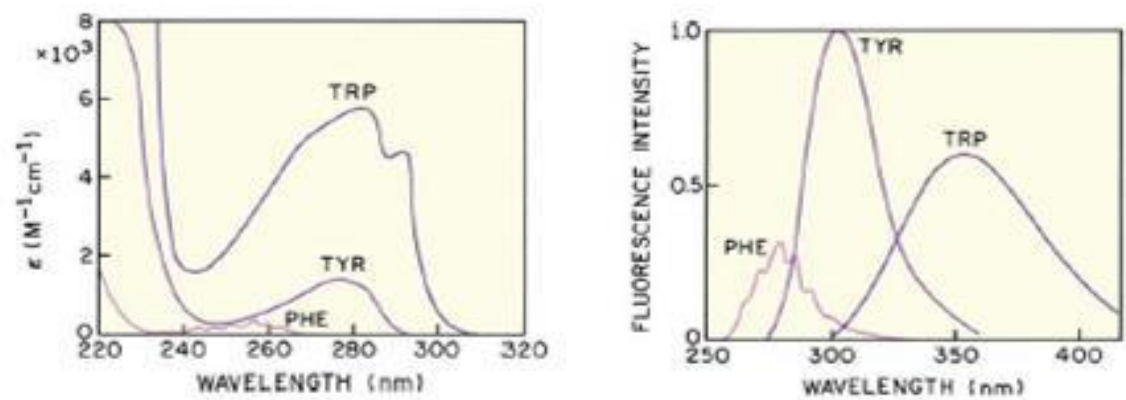

Figura 4.2.4 Espectros de absorción (A) y emisión (B) de los aminoácidos aromáticos fluorescentes a pH 7.0 en agua (Lakowicz JR 2006).

\subsubsection{2 .DESNATURALIZACIÓN CON GUANIDINA CLORHIDRICA}

La $\mathrm{GndHCl}$ es un agente caotrópico, es decir que tiene la capacidad de generar pérdida del plegamiento proteico (desnaturalización) y en consecuencia favorecer la exposición de los residuos aromáticos a la solución acuosa. La concentración de $\mathrm{GndHCl}$ necesaria para inducir la desnaturalización depende de la estabilidad conformacional de la proteína a analizar. En condiciones 
nativas, dichos residuos aromáticos se hallan protegidos al interior de la proteína, estabilizados en superficies hidrofóbicas formando parte de la estructura terciaria. Por tanto la desnaturalización puede ser evaluada mediante el corrimiento al rojo de la fluorescencia intrínseca a medida que la proteína pierde su conformación nativa ante agregados sucesivos del agente caotrópico. A tal fin las variantes con la secuencia nativa (Wt), y los mutantes W50R y L60R se diluyeron en buffer Tris salino ó buffer citrato fosfato $\mathrm{pH} 5.0$ (0.1 M ácido cítrico y $0.2 \mathrm{M} \mathrm{H}_{2} \mathrm{PO}_{4}$ ) a una concentración final de $0.2 \mathrm{mg} / \mathrm{ml}$. Se registraron los espectros de emisión de las variantes en buffer y posterior a cada agregado sucesivo de cantidades crecientes de $\mathrm{GndHCl}$ (0-3 M); se calculó el centro de masa del espectro en cada condición, con la longitud de onda de excitación a $295 \mathrm{~nm}$ y la emisión registrada entre 310 y 400 nm.

La fluorescencia intrínseca corresponde en promedio a los cuatro $\mathrm{W}$ presentes en la secuencia nativa de ApoA-I (8, 50,72 y108). Los espectros se registraron en un espectrofluorómetro SLM4800, actualizado por Olis (ISS Inc., Champaign, IL). A partir de los datos experimentales se puede calcular el $\Delta \mathrm{G}^{\circ}$ de desnaturalización, parámetro que indica la energía libre a la cual la proteína se encuentra en ausencia de agente desnaturalizante (estabilidad proteica). La dependencia de $\Delta \mathrm{G}$ con la concentración de $\mathrm{GndHCl}$ (Pace CN 1986) puede ser deducida como:

$\Delta \mathrm{G}=\Delta \mathrm{G}^{\circ}+\mathrm{m}[\mathrm{GndHCl}](1)$

El parámetro $\mathrm{m}$ fue considerado como proporcional a la exposición de la superficie hidrofóbica en función de la desnaturalización. En términos de la fracción de proteína desplegada $(\mathrm{ag})$ a cada [GndHCl], la ecuación (1) puede ser expresada como:

$\ln [\alpha g / 1-\alpha g]=\operatorname{lnKO}+m[\mathrm{GndHCl}] / \mathrm{RT}(2)$

donde $\mathrm{K}_{0}$ es la constante de equilibrio en ausencia de $\mathrm{GndHCl}$, R es la constante de gases y $\mathrm{T}$ es la temperatura de trabajo $\left(298^{\circ} \mathrm{K}\right)$. Del gráfico lineal de In [ag /1-ag] vs [GndHCl], es posible obtener $\mathrm{K}_{0}$ de la ordenada al origen, y de allí $\Delta \mathrm{G}^{0}$ como:

$\Delta G^{0}=-R T \ln K_{0}(3)$ 


\subsubsection{APAGADO (“QUENCHING") DE FLUORESCENCIA POR ACRILAMIDA}

El quenching hace referencia a los diversos procesos que traen en consecuencia un decaimiento de la emisión de una molécula fluorescente en una solución acuosa en presencia de una sustancia denominada apagador o "quencher". El apagamiento se puede clasificar en estático cuando se forma el complejo fluoróforo-quencher o dinámico (colisional) cuando la disminución de fluorescencia ocurre por choque de las moléculas en solución. En nuestro caso se analizó el quenching dinámico de los W (molécula excitada) por el quencher acrilamida $(Q)$ dada su solubilidad en medio acuoso. La efectividad de esta determinación nos permite comparar el grado de exposición de los aminoácidos al solvente, e inferir el entorno de los mismos en la proteína. La ecuación que rige este proceso de apagado de señal en función de la concentración $Q$ es la siguiente.

Ecuación de Stern Volmer

$$
F 0 / F=1+K s v[Q]
$$

donde F0 y $\mathrm{F}$ son las intensidades de emisión fluorescente en ausencia y presencia de una concentración del quencher [Q] respectivamente, y Ksv es la constante de Stern-Volmer. Esta constante indica la sensibilidad del fluoróforo al quencher. Un fluoróforo protegido en una macromolécula es usualmente inaccesible al quencher disuelto en solvente acuoso, resultando en un valor de Ksv bajo.

Las proteínas fueron diluidas en buffer Tris ó buffer citrato fosfato a pH 5.0 a una concentración final de $0.1 \mathrm{mg} / \mathrm{ml}$ y el espectro de emisión de los $\mathrm{W}$ fue registrado como mencionado arriba, midiendo la intensidad de fluorescencia en función de concentraciones crecientes de acrilamida (0-0.4 M) Luego se calculó Ksv por la ecuación (4).

\subsubsection{FLUORESCENCIA DEL Bis-ANS}

La sonda Bis-ANS tiene la capacidad de unirse a los bolsillos hidrofóbicos de la proteína, en especial en el estado de glóbulo fundido (Munishkina LA 2007). 
Dado que el rendimiento cuántico en agua es muy bajo y aumenta significativamente al unirse a proteínas, se ha analizado la intensidad y la longitud de onda máxima para obtener información del arreglo espacial de las variantes en estudio. Se realizó la titulación de las proteínas en concentración final $0.1 \mathrm{mg} / \mathrm{ml}$ en buffer Tris en presencia de concentraciones crecientes de la sonda (0-16 $\mu \mathrm{M})$. El espectro de fluorescencia fue registrado como fue descrito arriba, fijando la longitud de onda de excitación a $395 \mathrm{~nm}$ y el rango de emisión de $450-550 \mathrm{~nm}$.

\subsubsection{DETECCIÓN DE AGREGADOS PROTEICOS POR TIOFLAVINA T Y DISPERSIÓN DE LUZ}

La dispersión de luz es directamente proporcional al tamaño de las partículas presentes en una solución (Lakowicz JR 1986) y por tanto este parámetro permitió estimar la formación de complejos durante los periodos de incubación de proteínas en diversas condiciones. La sonda tioflavina T (ThT) es ampliamente usada ya que en presencia de proteínas la emisión de fluorescencia es directamente dependiente de la estructura hoja $\beta$, y de ahí extrapolado a la formación de agregados proteicos tipo amiloide, ya que ésta es una característica relativamente general para diversas proteínas (Levine H 1999).

Las proteínas fueron incubadas a $\mathrm{pH} 7.4$ y 5.0 en buffer citrato fosfato en una concentración final $0.2 \mathrm{mg} / \mathrm{ml}$ durante $48 \mathrm{~h}$ a $37^{\circ} \mathrm{C}$ con agitación constante. Se registró la dispersión de la luz a $340 \mathrm{~nm}$ (en un lector de placas Beckman DTX 880). Luego se agregó ThT en relación molar 1:1 sonda a proteína, y se midió en el mismo equipo intensidad de fluorescencia, utilizando filtros de excitación a 430 nm y emisión a $480 \mathrm{~nm}$.

\subsubsection{PLEGAMIENTO EN PRESENCIA DE UREA}

Se incubó Wt y sus variantes a concentración final de $0.2 \mathrm{mg} / \mathrm{ml}$ a pH 7.4 y 5.0 en buffer citrato fosfato con urea $0.6 \mathrm{M}$ durante $72 \mathrm{~h}$ a $37^{\circ} \mathrm{C}$ con agitación constante. Se midió intensidad de ThT en las condiciones descriptas 
anteriormente; para evitar que la urea tenga impurezas, fue necesario recristalizarla previamente al ensayo de agregación empleando el siguiente protocolo:

Se pesaron $5 \mathrm{~g}$ de urea y se diluyó en $10 \mathrm{ml}$ de etanol en un erlenmeyer conectado a un refrigerante de Liebig estándar 14/20 (Facultad de Ciencias Exactas UNLP); se disolvió la urea en caliente (hasta ebullición). Posteriormente se retiró el equipo de recristalización del calor y se dejó enfriar para la formación de cristales que están en contacto con las aguas madres impuras que fueron separadas por medio de filtración al vacío. La urea recristalizada se dejó secar en desecador hasta su uso.

\subsubsection{UNIÓN DE LAS PROTEÍNAS A LIGANDOS CELULARES}

Se incubaron Wt y sus variantes a una concentración final de $0.2 \mathrm{mg} / \mathrm{ml} \mathrm{a}$ pH 7.4 y 5.0 con heparina (utilizada como modelo de GAG) en una relación molar 2:1 heparina: proteína durante $48 \mathrm{~h}$ a $37^{\circ} \mathrm{C}$ en agitación constante. Se midió dispersión de luz e intensidad de ThT siguiendo el procedimiento anterior.

Otro modelo de ligando ensayado fue el dodecil sulfato de sodio (SDS). Se propone al SDS como modelo de lípido de naturaleza anfipática: cabeza sulfatada negativa y una cola hidrocarbonada de dodecilo. Las proteínas se incubaron a una concentración final de $0.2 \mathrm{mg} / \mathrm{ml}$ en presencia o ausencia 0.2 $\mathrm{mM}$ de SDS (valor por debajo de la concentración micelar crítica (CMC)) durante 48 h a $37^{\circ} \mathrm{C}$ con agitación a pH 7.4 (Rosú SA 2015).

A fin de indagar la naturaleza de la interacción ligando anfipáticoproteínas, se registró la fluorescencia intrínseca de Wt ó L60R $(0.2 \mathrm{mg} / \mathrm{ml})$ en presencia de distintas concentraciones de SDS: submicelares $(0,0.1 \mathrm{mM}, 0.3$ $\mathrm{mM})$, a la CMC estimada (0.7 $\mathrm{mM})$ y supramicelar (2 $\mathrm{mM})$. Posteriormente estas proteínas se incubaron a las mismas relaciones con SDS durante $48 \mathrm{~h}$ a $37^{\circ} \mathrm{C}$ (Giehm L 2010) y se determinó fluorescencia asociada a ThT como fue descrito arriba. 


\subsubsection{DICROISMO CIRCULAR (CD)}

Es una técnica utilizada para obtener información estructural de las proteínas debido a que son capaces de presentar señal dicroica por poseer quiralidad debido a la asimetría de los sustituyentes en los enlaces peptídicos. Para la medida de CD es necesario distinguir dos regiones espectrales: UV lejano (180-250 nm) y UV cercano (250-340 nm). El espectro de CD en el UV lejano nos permite observar el contenido global de estructura secundaria (alfa, beta o desordenada (random coil); el principal cromóforo es el enlace peptídico, ya que según su disposición espacial relativa genera espectros diferentes de CD (Córsico B 2013); en la Figura 4.2 .5 se visualiza el patrón de estructuras secundarias más comunes presentes en las proteínas. De los espectros registrados, puede calcularse ya sea el contenido de alfa hélice (por el valor de

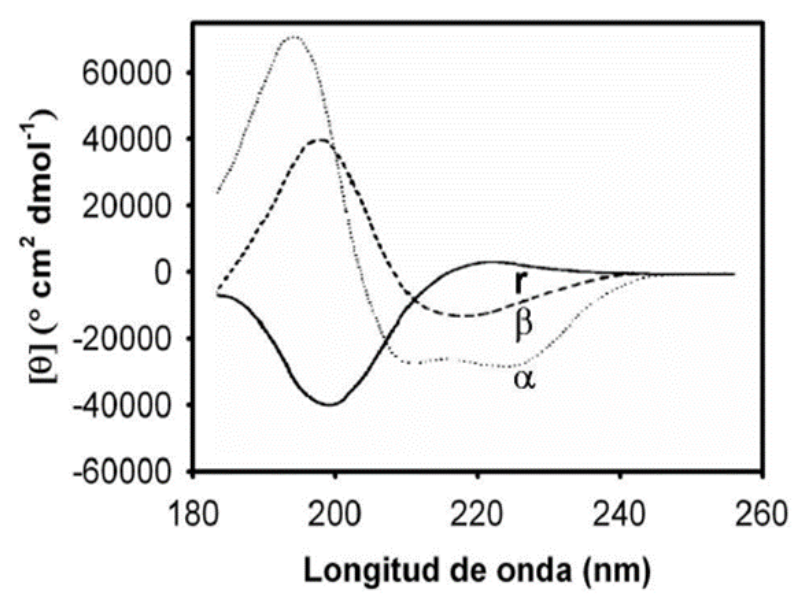

Figura 4.2.5 Espectro de CD lejano. Un valle cercano a $222 \mathrm{~nm}$ es característico de estructura alfa (Córsico B 2013)

elipticidad molar a $222 \mathrm{~nm}$ ), o mediante su comparación con espectros de proteínas cuya estructura cristalina es conocida, comparando con algoritmos descriptos por distintos predictores (Greenfield NJ 2015).

El espectro en el UV cercano es único de cada proteína ("huella digital”) y nos brinda información acerca de la contribución estructural de aminoácidos aromáticos y puentes disulfuro; permite conocer características de la estructura terciaria de las mismas y establecer comparación entre secuencias nativas 
respecto a sus variantes. A modo de ejemplo en la Figura 4.2.6 se visualiza los espectros de CD cercano presentes en algunas proteínas

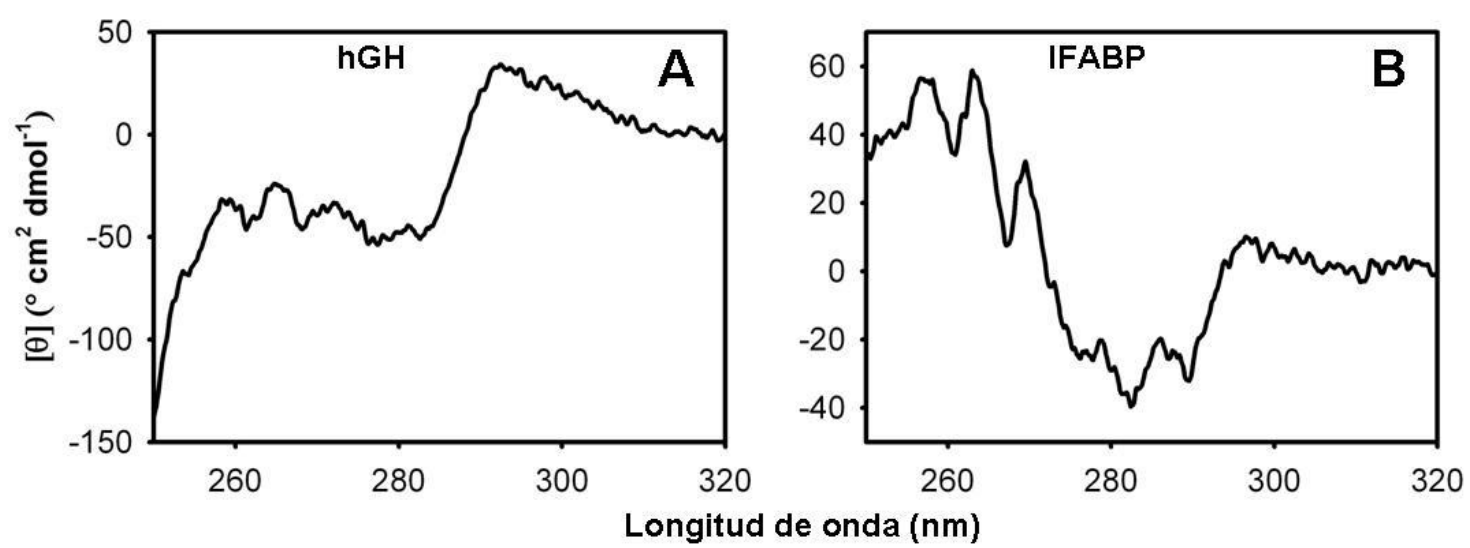

Figura 4.2.6. Espectros de CD UV cercano (A) Hormona gonadotrofina coriónica y (B) proteína unidora de ácidos grasos intestinal (Córsico B 2013).

Para la medición se utilizó un espectropolarímetro Jasco J-810 (IQUIFIB, Facultad de Farmacia y Bioquímica de la UBA), con la colaboración de la Dra Lucrecia Curto. Los datos fueron colectados utilizando una cubeta de $1 \mathrm{~mm}$ de paso óptico. En el UV lejano $(200-250 \mathrm{~nm})$ las proteínas se llevaron a $0.2 \mathrm{mg} / \mathrm{ml}$

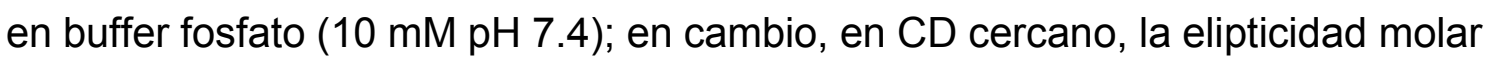
fue registrada en el rango de 250-320 nm a una concentración de 1.0, 1.5 y 1.5 $\mathrm{mg} / \mathrm{ml}$ para Wt, W50R y L60R respectivamente en el mismo buffer. La velocidad de escaneo fue de $20 \mathrm{~nm} / \mathrm{min}$ con una constante de $1 \mathrm{seg}$ de tiempo tanto para Wt como para las dos variantes analizadas. Cada espectro se midió al menos tres veces y los datos se promediaron para reducir al mínimo el ruido. Para determinar si existe una disminución del contenido de $\alpha$ hélice en las variantes naturales de ApoA-I respecto a la secuencia nativa se utilizó el algoritmo CONTIN (Greenfield NJ 2015).

\subsubsection{CROMATOGRAFÍA LÍQUIDA DE ALTA RESOLUCIÓN}

El probable efecto que las mutaciones puedan tener sobre el estado de oligomerización de la ApoA-I se analizó mediante cromatografía de exclusión molecular, técnica que permite separar moléculas de acuerdo al tamaño. Las 
proteínas fueron llevadas a $0.5 \mathrm{mg} / \mathrm{ml}$ en buffer fosfato $\mathrm{pH} 7.4$ y luego fueron eluidas a través de una columna de exclusión Superdex 75 10/300 GL (Amersham Pharmacia) con un flujo de $0.5 \mathrm{ml} / \mathrm{min}$ en el mismo buffer. Todo este sistema se encuentra acoplado a un detector UV-visible Merck-Hitachi L4200, con absorción a $280 \mathrm{~nm}$ para detectar aminoácidos aromáticos (Morgado I 2018).

\subsubsection{VISUALIZACIÓN DE LOS AGREGADOS PROTEICOS}

\subsection{MICROSCOPÍA ELECTRÓNICA DE TRANSMISIÓN (MET)}

El microscopio de MET utiliza como fuente un haz de electrones acelerados provenientes del calentamiento de un filamento de tungsteno al vacío; parte de éstos son absorbidos y el resto atraviesan a la muestra que está colocada sobre una rejilla delgada (Elis RA 1979). Para la visualización es necesario agregar ácido fosfotúngstico, el que se deposita alrededor de la muestra, generando un contraste que permite mejor definición mediante "tinción negativa". Las proteínas fueron incubadas a $37^{\circ} \mathrm{C}$ a pH 7.4 durante 7 días a una concentración final de $0.6 \mathrm{mg} / \mathrm{ml}$. Se depositaron sobre las grillas durante $5 \mathrm{~min}$, se removió el excedente y se agregó ácido fosfotúngstico al $0.5 \%$ durante 5 min. Se visualizaron en un equipo JEOL-1200 EX operando a $100 \mathrm{kV}$ (Facultad de Ciencias Veterinarias, UNLP).

\subsection{MICROSCOPÍA DE FUERZA ATÓMICA (AFM)}

Otra técnica microscópica que brinda información de alta resolución es la AFM. En este caso una sonda o micro palanca adosada al microscopio barre la superficie de la muestra y registra continuamente su topografía, por lo que brinda información especialmente sensible al espesor y morfología del material a observar. Igual que en el caso anterior, Wt y L60R fueron incubadas durante 7 días en agitación constante a $37^{\circ} \mathrm{C}$ a una concentración final de $0.6 \mathrm{mg} / \mathrm{ml} \mathrm{y} \mathrm{pH}$ 7.4. Se tomaron $10 \mu \mathrm{l}$ de muestra y se colocó en un soporte de mica. La muestra se dejó secar en una atmosfera saturada con $\mathrm{N}_{2}$, luego se lavó en dos oportunidades con $\mathrm{H}_{2} \mathrm{O}$ des ionizada para remover sales y se dejó secar nuevamente (Ramella NA 2012). Todas las imágenes se obtuvieron usando un 
microscopio Multimode Nanoscope (Veeco, Santa Bárbara, CA) operando en "tapping-mode" empleando una punta modelo Arrow-NCR-50 Nano World, con una frecuencia de resonancia de $258 \mathrm{kHz}$, constante de fuerza de $42 \mathrm{~N} / \mathrm{m}$ y radio de la punta de 5-10 nm (Instituto de Investigaciones Fisicoquímicas Teóricas y Aplicadas, La Plata (INIFTA)), con la colaboración del Dr Eduardo Prieto.

\subsubsection{ENSAYO DE FUNCIÓN. ACLARAMIENTO DE LIPOSOMAS DE DI MIRISTOIL FOSFATIDIL COLINA (DMPC)}

Para evaluar el probable efecto de las mutaciones sobre la conocida función de la ApoA-I en la solubilización de lípidos, se estudió la habilidad de las proteínas en el aclaramiento de DMPC, lo que ha sido tradicionalmente utilizado con este fin (Pownall HJ 1978). La proteína interactúa con fosfolípidos a su temperatura de transición, formando de manera eficiente partículas discoidales. Este evento se pone de manifiesto siguiendo la disminución de absorbancia a partir de DMPC en una dispersión de liposomas multilamelares. El DMPC se solubilizó en cloroformo y las cantidades deseadas se secaron en forma de película bajo flujo de $\mathrm{N}_{2}$ y posterior vacío para remover restos de solvente. $\mathrm{A}$ continuación los lípidos fueron resuspendidos en buffer Tris, y los liposomas multilamelares (MLV) se obtuvieron mediante agitación exhaustiva en vórtex. Para el ensayo de aclaramiento lipídico, las proteínas (Wt y L60R), a una concentración final de $0.2 \mathrm{mg} / \mathrm{ml}$, se incubaron con DMPC MLV a una relación molar de lípido: proteína 80: 1 a $24{ }^{\circ} \mathrm{C}$ (temperatura de transición del lípido) durante $120 \mathrm{~min}$. La absorbancia se monitoreó en el lector de microplacas configurando los filtros a $350 \mathrm{~nm}$.

\subsubsection{PROCESAMIENTO PROTEOLITICO.}

La flexibilidad estructural de una proteína puede ser estimada analizando la susceptibilidad a la proteólisis parcial, dado que indicaría la exposición relativa de sitios de corte. Se estudió la susceptibilidad a la proteólisis de W50R y L60R, en comparación a la Wt. Como modelo de enzimas proteolíticas se utilizaron la Tripsina, la Metaloproteinasa 12 (MMP-12) y quimotripsina. En este ensayo 0.3 
$\mathrm{mg} / \mathrm{ml}$ de ApoA-I y sus variantes fueron sometidas a una proteólisis a $\mathrm{pH}$ fisiológico a $37^{\circ} \mathrm{C}, 900 \mathrm{rpm}$ durante $1 \mathrm{~h}$, empleando diversas proteasas, cada una ellas en diferente relación molar proteína-enzima: tripsina (1000:1), quimotripsina (5000:1) y MMP-12 (500:1). Se tomaron alícuotas cada 15 min durante $1 \mathrm{~h}$, se frenó la reacción por adición de buffer muestra con SDS y 2 min a $95^{\circ} \mathrm{C}$. Los productos de proteólisis fueron analizados por SDS PAGE al $16 \%$ teñido con la técnica de nitrato de plata. A fin de tener mayor información sobre el producto de tripsinólisis; las muestras se analizaron además mediante Western Blot luego de ser desarrolladas en un gel desnaturalizante en gradiente $12-24 \%$.

\subsubsection{ACTIVACIÓN DE MACRÓFAGOS HUMANOS}

A fin de poner de manifiesto una probable activación de respuesta proinflamatorio como mecanismo de toxicidad, se ensayó la liberación de citoquinas a partir de un cultivo de macrófagos mediado por las variantes W50R y L60R. Se ensayó la producción de IL-1 $\beta$ y TNF $\alpha$ partir de monocitos THP-1 (ECACC, UK). Los monocitos fueron cultivados en medio RPMI 1640 (Gibco) con mezcla de antibiótico antimicótico (Thermo Fisher) y 10\% suero fetal bovino (SFB) (Natocor) a $37^{\circ} \mathrm{C}$ y $5 \%$ de $\mathrm{CO}_{2}$ en una estufa de cultivo. La diferenciación de los monocitos a macrófagos se llevó a cabo en placas de 48 well a $37^{\circ} \mathrm{C}$, sembrando $1 \times 10^{7}$ células $/ \mathrm{ml}$ en contacto con $5 \mathrm{ng} / \mathrm{ml}$ de PMA (Ester de forbol) durante $48 \mathrm{~h}$, con renovación de la mitad de volumen del medio suplementado con el agente activador a las primeras $24 \mathrm{~h}$; durante este proceso las células se transforman a macrófagos y se fijan a la placa (Park EK 2005). Los macrófagos fueron incubados con Wt y sus variantes a una concentración final de $1 \mu \mathrm{g} / \mathrm{ml}$ en medio RPMI para TNF a, y $0.5 \mu \mathrm{g} / \mathrm{ml}$ para IL-1 $\beta$, con $0.5 \%$ SFB durante $3 \mathrm{~h}$ a $37^{\circ} \mathrm{C}$. A fin de inhibir cantidades mínimas de endotoxinas que puedan quedar presentes durante el proceso de purificación, se adicionó polimixina $B(2.5 \mu \mathrm{g} / \mathrm{ml})$. Como control positivo se utilizó lipopolisacárido bacteriano (LPS) $(50 \mathrm{ng} / \mathrm{ml})$ y como control negativo, LPS con polimixina B. Luego de $3 \mathrm{~h}$ se tomó todo el sobrenadante y centrifugó a $2100 \mathrm{rpm} 10 \mathrm{~min}$ para sacar posibles restos celulares; posteriormente se realizó la técnica de ELISA para medir las citoquinas 
mencionadas a $450 \mathrm{~nm}$ (en el lector de placas) según los protocolos descriptos en el kit. La cuantificación se realizó por comparación con una curva estándar (eBioscience, San Diego, CA).

\section{RESULTADOS}

\subsection{PURIFICACIÓN DE APOA-I Y SUS VARIANTES}

La eficiencia en la purificación de ApoA-I y sus variantes se chequeó mediante electroforesis en geles de poliacrilamida. En la primera etapa se separó la proteína con la cola de His mediante competencia con alta concentración de imidazol (línea 7 en la Figura 5.1 A). Luego se procedió al corte químico de la fracción pura con ácido fórmico y se empleó nuevamente la columna de níquel para obtener la proteína sin cola de Histidina como se ve en la Figura 5.1 B; la proteína así obtenida tiene elevado grado de pureza (calles 2-4).

A

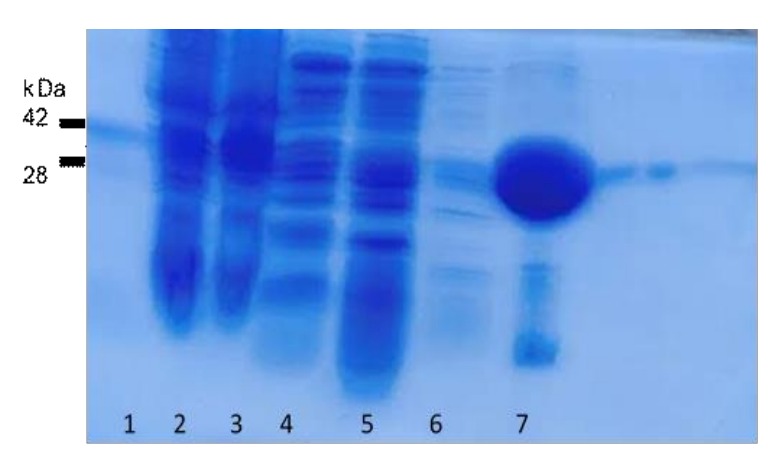

B

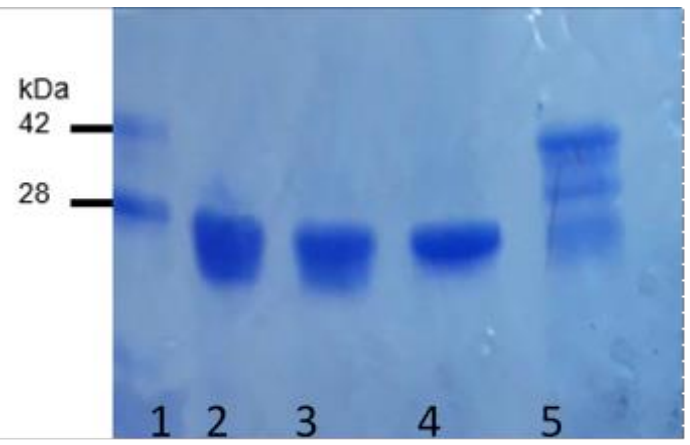

Figura 5.1.Caracterización del grado de pureza de variantes. Geles de poliacrilamida SDS PAGE al 14\% teñidos con Coomassie blue. A) Expresión de Wt desde E Coli BL21 y primer etapa 
de purificación. Calle 1: estandar de peso molecular ApoA-I con la cola His (42 kDa) y ApoA-I con la secuencia completa ( $28 \mathrm{kDa}$ ), calles 2 y 3 lisado de bacterias en ausencia y presencia de IPTG respectivamente, calles 4-5 fracciones de elución de muestra sin imidazol, calle 6 fracción de bajo de imidazol (lavado), calle 7 fracción buffer de alto contenido de imidazol (elución); B) Purificación luego del corte químico. Calles 1 y 5 estándar de ApoA-I con o sin la cola de His, calles 2-4 fracciones puras de ApoA-I sin cola.

\subsection{COMPARACIÓN ESTRUCTURAL Y ESTABILIDAD}

La estabilidad estructural fue analizada mediante curvas de desnaturalización en presencia de concentraciones crecientes de $\mathrm{GndHCl}$ registrando el espectro de fluorescencia intrínseca de W. Dada la localización de estos residuos en la secuencia, censan en promedio el extremo $\mathrm{N}$ de la proteína (W8, W50, W72 y W108) (Davidson WS 1999). Como se ha comentado, la fluorescencia de estos aminoácidos es altamente sensible al entorno y brinda gran información sobre el plegamiento proteico. El patrón de desnaturalización química de la proteína con la secuencia nativa $(\mathrm{Wt})$ fue descripto previamente por distintos grupos incluyendo el nuestro (Eckhardt D 2018, Del Giudice R 2016, Ramella NA 2012, Rosú SA 2015). La dependencia del centro de masa con la concentración de $\mathrm{GndHCl}$ (a bajas concentraciones de proteína) puede simularse, dado el efecto cooperativo de esta transición, mediante un modelo de dos estados (monómero nativo - monómero desnaturalizado) y calcular de allí la energía libre involucrada en el proceso; este experimento también se ha realizado a $\mathrm{pH}$ acido, debido a que en procesos inflamatorios este parámetro puede descender ligeramente y es de sumo interés entender si este fenómeno contribuye a perturbar la estructura de Wt y sus variantes (Oorni K 2014).

El comportamiento de las variantes a ambos $\mathrm{pH}$ está graficado en la Figura 5.2. Como era esperable a estudios previos, el $\Delta G^{\circ}$ de desnaturalización de $\mathrm{Wt}$ a pH 7.4 fue de $2.3+/-0.1 \mathrm{kcal} / \mathrm{mol}$, típico de una proteína parcialmente plegada. De igual manera se estudiaron las dos variantes involucradas en este trabajo. La desnaturalización de W50R también puede aproximarse al modelo mencionado, estimando un $\Delta G^{\circ}$ menor $(1.7+/-0.1 \mathrm{kcal} / \mathrm{mol}$, tabla 1$)$. L60R evidenció pérdida más extrema del efecto cooperativo en el proceso, lo que se observa ya que aún el menor agregado de pequeñas concentraciones de $\mathrm{GndHCl}$ produjo un corrimiento hacia el rojo respecto a Wt consecuente con un 
grado de exposición mayor de W (Figura 5.2.A). Por lo tanto, la curva no ajusta al modelo de dos estados imposibilitando la determinación de la energía libre de desnaturalización. En condiciones ácidas se pudo apreciar la misma tendencia (Figura 5.2 B).

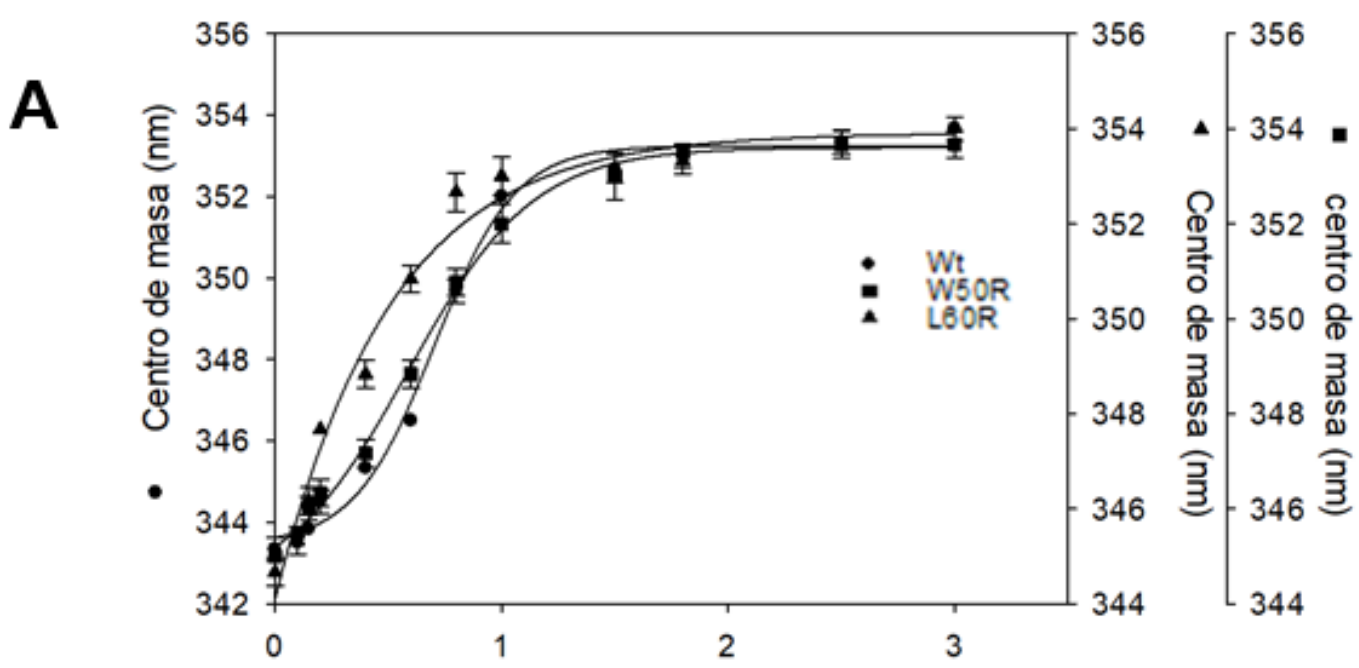

[Gnd $\mathrm{HCl}](\mathrm{M})$

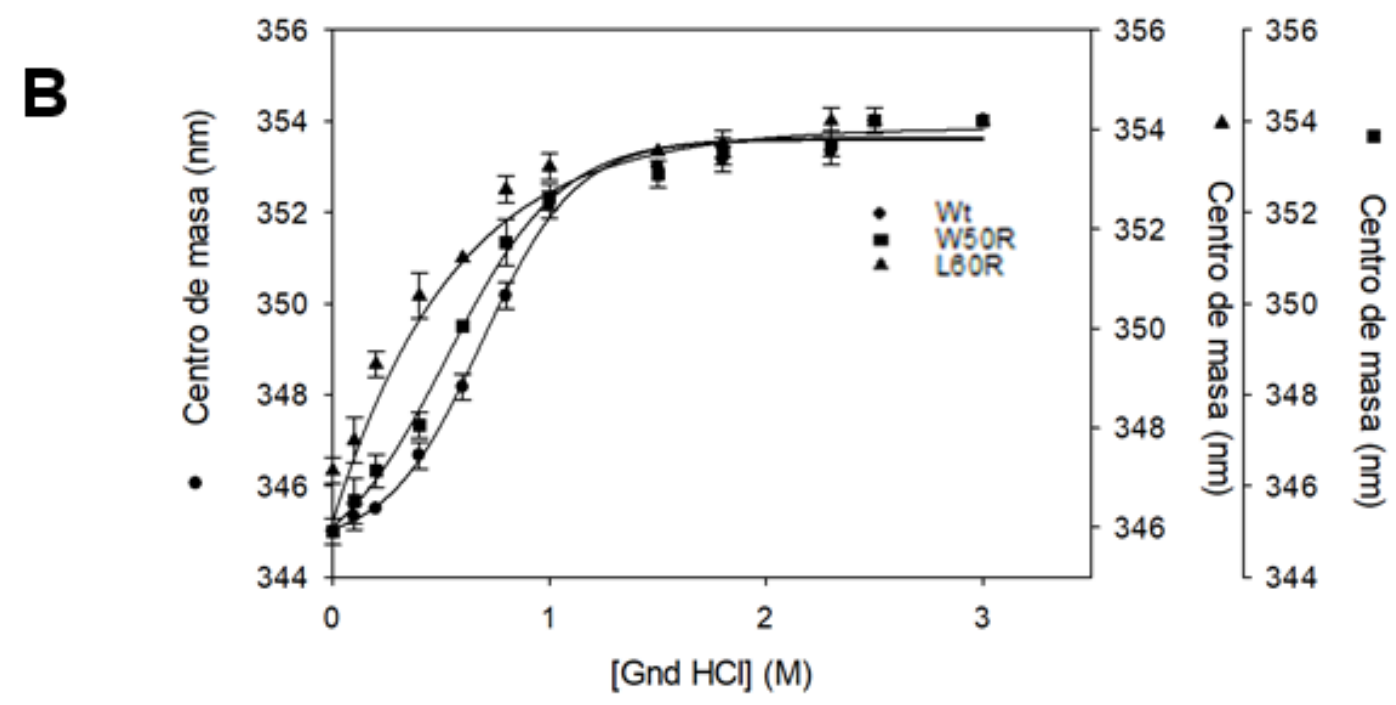

Figura 5.2. Desnaturalización química mediada por GndHCI. A) pH 7.4 B) pH 5.0. Wt (círculo), W50R (cuadrado) y L60R (triángulo). $0.2 \mathrm{mg} / \mathrm{ml}$ de las proteínas fue titulado en presencia de concentraciones crecientes de $\mathrm{GndHCl}$ (0-3 M). Se midió la fluorescencia intrínseca de W mediante excitación a $295 \mathrm{~nm}$ y posterior registro del espectro de emisión de 310-400 nm. Con los datos obtenidos se calculó el centro de masa para cada concentración. A fin de comparar mejor el patrón de desnaturalización se graficó en el eje $\mathrm{Y}$ izquierda el dato para Wt y en el eje $\mathrm{Y}$ derecha los valores para W50R y L60R. 
Parte de los datos estructurales obtenidos mediante estas determinaciones están resumidos en la tabla 5.1

Tabla 5.1: Parámetros estructurales obtenidos mediante análisis de fluorescencia intrínseca

\begin{tabular}{|c|c|c|c|c|c|c|c|c|}
\hline & $\begin{array}{l}\lambda \text { máximo } \\
(\mathrm{nm}) \mathrm{pH} \\
7.4\end{array}$ & $\begin{array}{l}\text { Intensidad } \\
\text { relativa } \\
\text { pH } 7.4\end{array}$ & $\begin{array}{l}{\left[\mathrm{GndHCl}_{1 / 2}(\mathrm{M})\right.} \\
\mathrm{pH} 7.4\end{array}$ & $\begin{array}{l}\Delta \mathrm{G}^{0}(\mathrm{kcal} / \mathrm{mol}) \\
\mathrm{pH} 7.4\end{array}$ & $\begin{array}{l}\lambda \text { máximo } \\
(\mathrm{nm})\end{array}$ & $\begin{array}{l}\text { Intensidad } \\
\text { relativa } \\
\text { pH } 5.0\end{array}$ & $\begin{array}{l}{\left[\mathrm{GndHCl}_{1 / 2}(\mathrm{M})\right.} \\
\mathrm{pH} 5.0\end{array}$ & $\begin{array}{l}\Delta \mathrm{G}^{0}(\mathrm{kcal} / \mathrm{mol}) \\
\mathrm{pH} 5.0\end{array}$ \\
\hline WT & $338+/-1$ & $5.5+1-0.3$ & $0.9+\mid-0.1$ & $2.3+1-0.1$ & $339+1-2$ & $6.3+1-0.3$ & $0.8+\mid-0.1$ & $2.0+1-0.1$ \\
\hline W50R & $340+/-2$ & $3.8+1-0.5$ & $0.7+\mid-0.1$ & $1.7+/-0.1$ & $340+1-2$ & $4.1+1-0.7$ & $0.6+\mid-0.1$ & $1.5+\mid-0.1$ \\
\hline L60R & $342+1-2$ & $3.6+1-0.5$ & $0.6+/-0.1$ & ND & $342+1-2$ & $4.4+1-0.8$ & $0.5+1-0.1$ & ND \\
\hline
\end{tabular}

En la tabla 5.1 se puede apreciar que la variante L60R presenta un corrimiento espectral hacia el rojo de $4(+/-1) \mathrm{nm}$ y el W50R de $2(+/-1) \mathrm{nm}$ respecto a $\mathrm{Wt}$ a $\mathrm{pH}$ fisiológico; esto sugiere una conformación ligeramente más desplegada en estado nativo que el Wt. Otro parámetro que brinda información es [GndHCl] $1 / 2$, que se define como la concentración de guanidina a la cual existe igual concentración de especie nativa y desnaturalizada; los mutantes exhiben un valor menor de este parámetro respecto a $\mathrm{Wt}$, indicando un mayor grado de desplegamiento (e indirectamente de inestabilidad frente al agente caotrópico), en especial L60R. A pH ácido se puede apreciar la misma tendencia (Figura 5.2 B). La intensidad de fluorescencia intrínseca en ausencia de agente desnaturalizante a ambos $\mathrm{pH}$ es menor para ambas mutantes. Si bien este hallazgo puede ser predecible para W50R al perder un residuo W debido a la mutación, es una observación interesante para L60R, ya que podría evidenciar una desorganización estructural que permita la mayor exposición de los $\mathrm{W}$ respecto a la secuencia nativa. Para apoyar esta conclusión, se estudió comparativamente la intensidad total a medida que las proteínas son desnaturalizadas (Figura 5.3) confirmando que en las proteínas completamente desplegadas la intensidad total tiende a igualarse. 


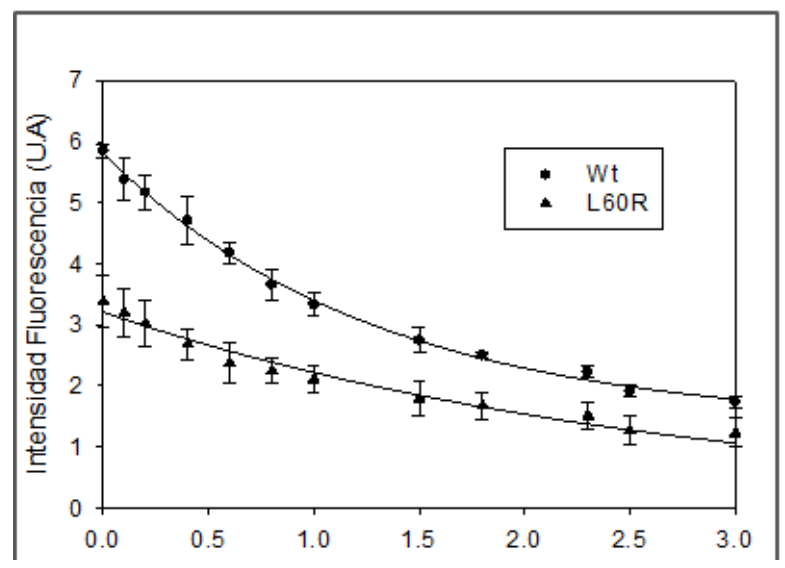

Figura 5.3. Intensidad de fluorescencia de $W$ para $W t$ y $L 60 R$ en función de la concentración de $\mathrm{GndHCl} .0 .2 \mathrm{mg} / \mathrm{ml}$ de las proteínas fueron tituladas en un rango 0-3 M de $\mathrm{GndHCl}$ y se registró la fluorescencia en cada punto.

Otro parámetro estructural a analizar es el grado de exposición relativa de los W de ApoA-I al solvente mediante el análisis del apagado de señal con concentraciones crecientes de acrilamida. Se calculó la constante de Stern Volmer (Ksv) y fa (fracción de W expuestos al solvente). Una mayor constante Ksv para ambos mutantes (directamente asociada a mayor pendiente en las gráficas de la Figura 5.4 A y $\mathrm{B}$ ) indica una mayor exposición relativa de estos residuos respecto al Wt (Tabla 2). W50R y L60R presentan un fa de 1, lo que implica que todos los $\mathrm{W}$ se encontraron expuestos respecto a Wt.
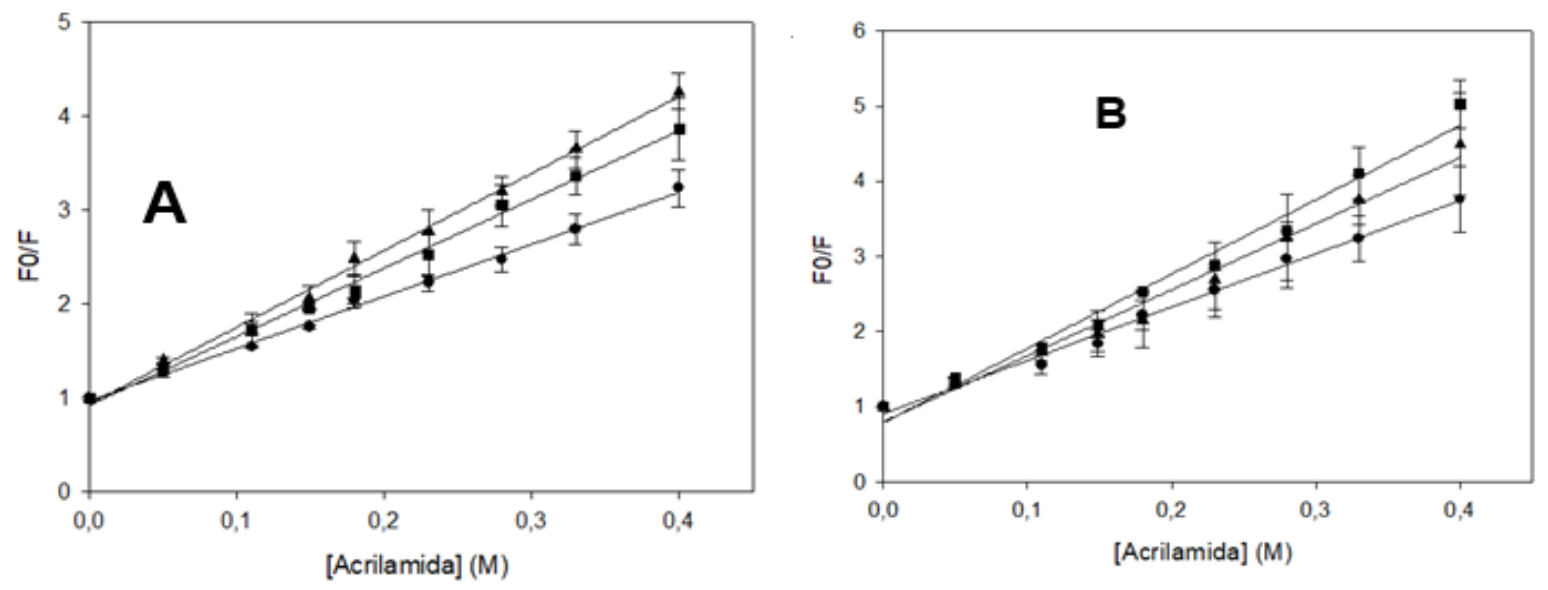

Figura 5.4. Quenching con acrilamida A) pH 7.4 B) pH 5. Wt (círculos), W50R (cuadrados) y L60R (triángulo). $0.1 \mathrm{mg} / \mathrm{ml}$ de las variantes fueron tituladas en presencia de concentraciones 
crecientes de acrilamida (0-0.4 M). Se excitó a $295 \mathrm{~nm}$ y se registró la fluorescencia intrínseca entre 310-400 nm. El gráfico muestra la relación lineal entre el cociente de fluorescencia en ausencia del quencher (F0) y la correspondiente a cada punto de la titulación (F) representada por la ecuación de Stern Volmer (ver Métodos). De la pendiente de esta representación se obtiene Ksv.

Tabla 5.2: valores de valores de apagado (Ksv y F) para los pH analizados.

\begin{tabular}{|c|c|c|c|c|}
\hline & $\mathrm{Ksv}\left(\mathrm{M}^{-1}\right) \mathrm{pH} 7.4$ & $\mathrm{Ksv}\left(\mathrm{M}^{-1}\right) \mathrm{pH} 5.0$ & Fa pH 7.4 & Fa pH 5.0 \\
\hline Wt & $5.6+/-0.3$ & $5.7+/-0.3$ & $0.8+/-0.3$ & $0.8+/-0.5$ \\
\hline W50R & $8.6+/-0.4$ & $8.7+/-0.4$ & $1+/-0.6$ & $1+/-0.4$ \\
\hline L60R & $8.3+/-0.4$ & $8.7+/-0.5$ & $1+/-0.3$ & $1+/-0.5$ \\
\hline
\end{tabular}

Para obtener mayor información sobre la conformación estructural de ApoA-I y sus variantes se titularon las proteínas con la sonda fluorescente BisANS, cuya afinidad por bolsillos hidrofóbicos se evidencia con un aumento de su rendimiento cuántico (Figura 5.5). En estudios previos fue demostrada alta eficiencia del Wt para unir esta sonda (Ramella NA 2012). La W50R exhibió un comportamiento similar a otros mutantes estudiados por el grupo (Rosú SA 2015, Ramella NA 2012), con mayor rendimiento cuántico respecto al Wt para cada concentración de sonda. En cambio L60R mostró niveles más bajos de intensidad de Bis-ANS en todos los puntos, lo que podría sugerir un menor contenido o menor accesibilidad a los bolsillos hidrofóbicos en la variante. 


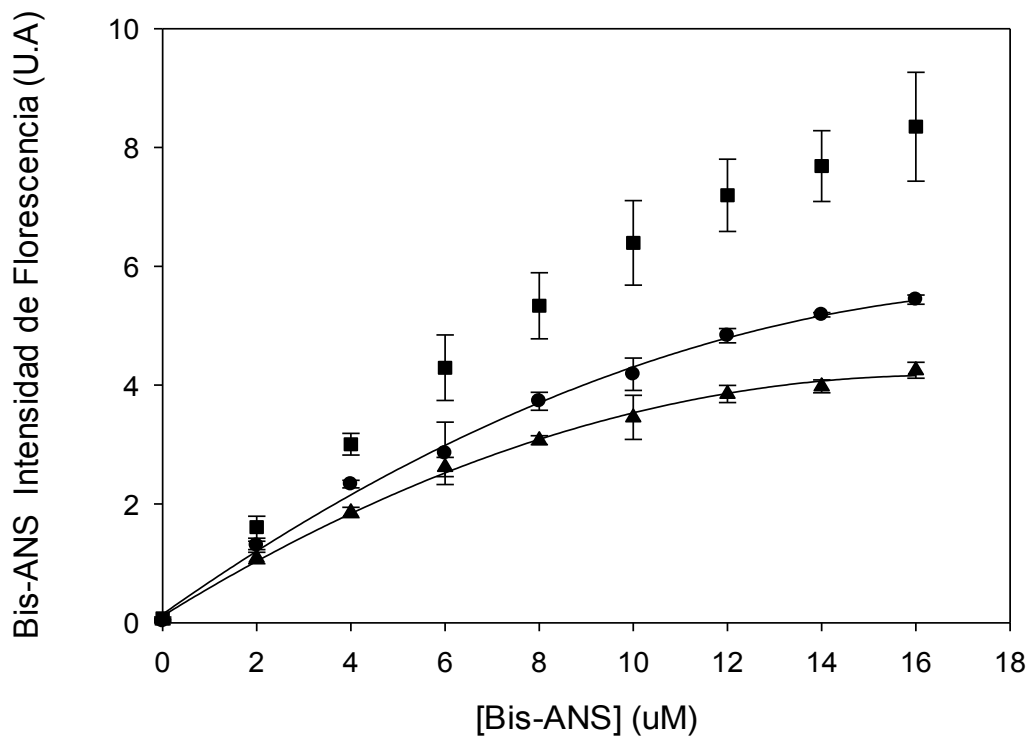

Figura 5.5: Titulación con Bis-ANS. $0.1 \mathrm{mg} / \mathrm{ml}$ de las proteínas fueron tituladas en presencia de concentraciones crecientes de la sonda $(0-16 \mu \mathrm{M})$, la cual fue excitada a $395 \mathrm{~nm}$ con registro de los espectros de fluorescencia en un rango de 450-550 nm. El gráfico representa la intensidad de fluorescencia máxima de cada punto en función de la concentración de sonda agregada. Wt (círculos), W50R (cuadrados) y L60R (triángulos)

Todos estos ensayos analizados en forma conjunta sugieren que W50R presenta ligeros cambios estructurales respecto al $\mathrm{Wt}$, con menor estabilidad estructural y una estructura espacial más flexible que permite una mayor permeación de Bis-ANS. El rearreglo del extremo $\mathrm{N}$ se manifiesta por un corrimiento mínimo en el espectro y mayor la exposición de los residuos W. El cambio observado en L60R es más drástico, exhibiendo mayor inestabilidad y pérdida del modelo cooperativo de desnaturalización. La exposición relativa de los W y el corrimiento más marcado del espectro indican también desorganización del extremo $\mathrm{N}$; la pérdida de bolsillos hidrofóbicos podría sugerirse dado el menor rendimiento cuántico del Bis-ANS

\subsection{PROCESAMIENTO PROTEOLÍTICO DE APOA-I Y SUS VARIANTES}

La presencia de un péptido $\mathrm{N}$ terminal en las lesiones de pacientes sugiere que algún mecanismo de proteólisis podría inducir un procesamiento de las variantes, rindiendo ya sea menor proteína circulante al catabolizarse, o incluso podría generar algún fragmento que sea per se más tóxico o con mayor 
tendencia a la agregación que la proteína con la secuencia completa. A fin de conocer si las variantes naturales de ApoA-I son más susceptibles a la proteólisis, éstas se incubaron con los enzimas Tripsina, y MMP-12 a pH fisiológico y $37^{\circ} \mathrm{C}$ frenando la reacción a distintos tiempos en el lapso de una hora; las fracciones se analizaron por geles de poliacrilamida con SDS al $16 \%$ teñidos por la técnica de nitrato de plata y luego las bandas fueron cuantificadas por el software Image J (1.51 j8).

A

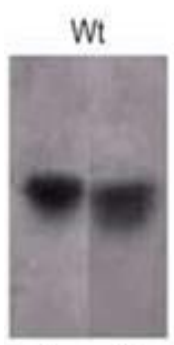

$0 \quad 60$

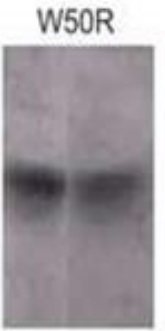

060

Tiempo (min)
B

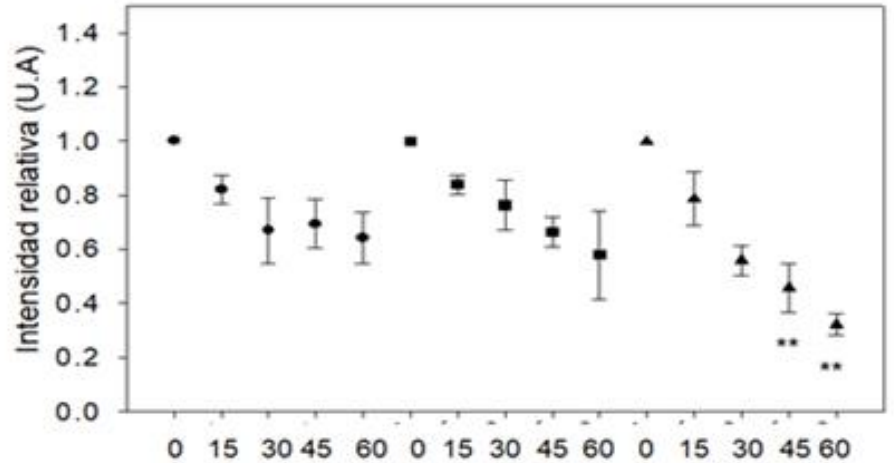

D

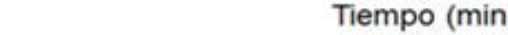

C
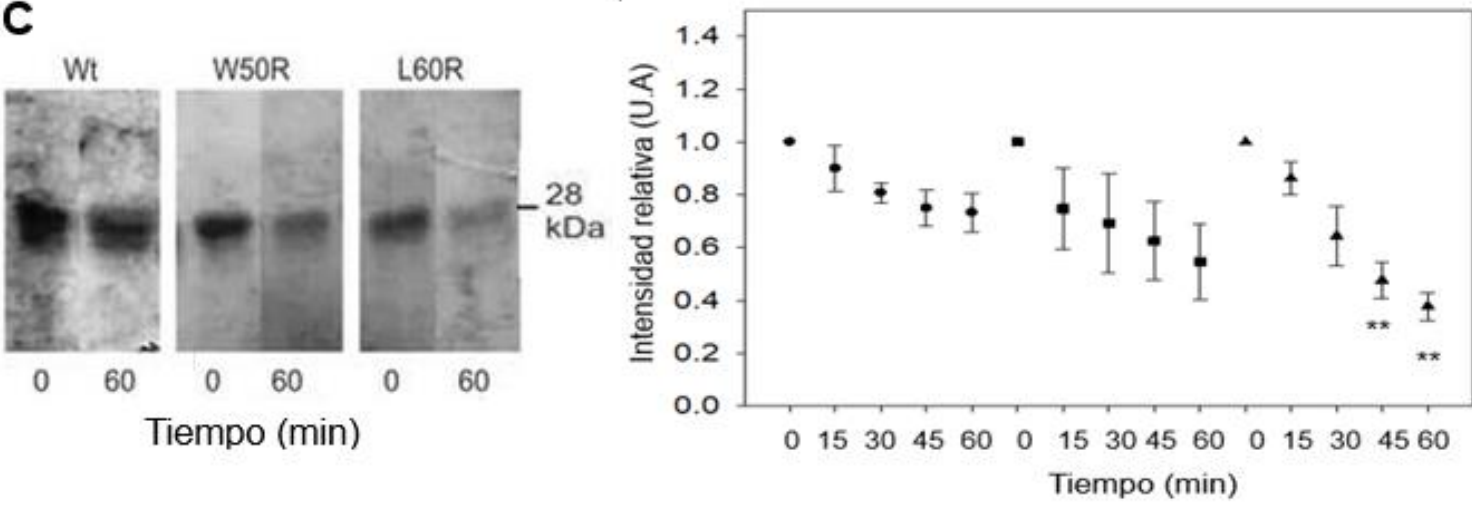

Figura 5.6. Proteólisis de Wt y L60R inducida por tripsina y MMP-12 humana. Las proteínas

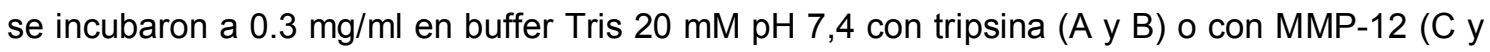
D). Después de diferentes tiempos, se detuvo las reacciones mediante la adición de buffer muestra y dos minutos de ebullición. Las muestras se resolvieron a través de un gel PAGE SDS (16\%) y se revelaron mediante tinción con plata. A) y C) Representación en blanco y negro de los tiempos de incubación inicial (0) y final (60 min). B) y D) La intensidad remanente con el peso molecular monomérico ( $28 \mathrm{kDa}$ ) después de cada tiempo de incubación se cuantificó mediante el software Image Quant y se normalizó a la intensidad de la banda en el tiempo = 0 para cada proteína. La densitometría fue obtenida de tres experimentos independientes y el resultado se 
expresa como el promedio +/- desvío estándar. Los círculos, cuadrados y triángulos corresponden a Wt, W50R y L60R respectivamente ${ }^{* *}$ representa $\mathrm{p}<0.001$ con respecto al mismo tiempo en Wt mediante test Student)

Como muestra la Figura 5.6 A y C, la eficiencia de proteólisis es evidente por la desaparición de la banda correspondiente al peso molecular de la ApoA-I (28 kDa); mientras que la susceptibilidad de W50R fue similar a la del Wt con ambas proteasas, L60R fue proteolizada con mayor susceptibilidad frente a las dos enzimas analizadas, lo cual se torna significativo a partir de los $45 \mathrm{~min}$.

Un resultado similar fue obtenido cuando la variante L60R fue incubada en presencia de quimotripsina en relación molar 5000:1 (Figura 5.7)

A

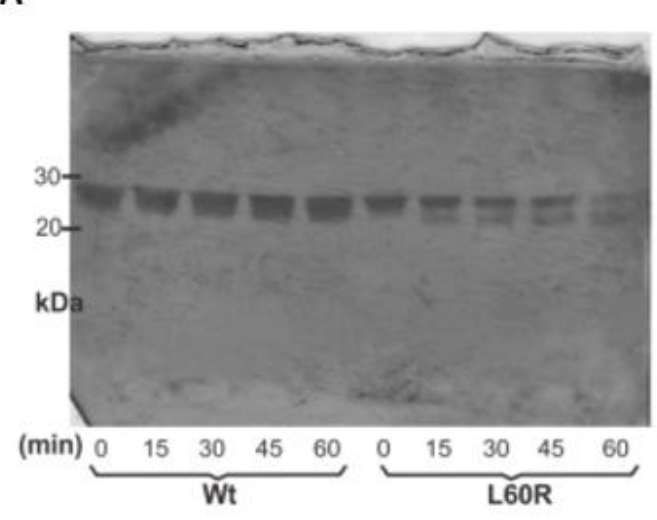

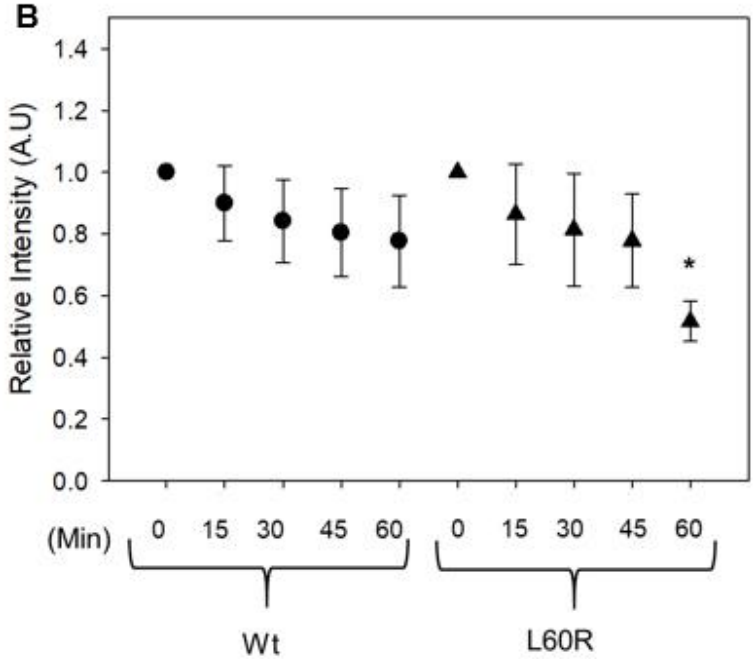

Wt
L60R

Figura 5.7. Proteólisis con quimotripsina de Wt y L60R. A) $0.3 \mathrm{mg} / \mathrm{ml}$ de las proteínas fueron incubadas con el enzima en una relación molar 5000:1. Se tomaron muestras del proceso durante una hora en intervalos de $15 \mathrm{~min}$, posteriormente la reacción se frenó con buffer muestra SDS, y las muestras se revelaron en un gel 16\% SDS PAGE con tinción de nitrato de plata. B) La cuantificación se realizó como se indica en la figura anterior. Wt (círculos) y L60R (triángulos).* representa $p<0.05$ con respecto al mismo tiempo en Wt mediante test Student)

Para caracterizar con mayor detalle el producto de la proteólisis de L60R, las muestras tratadas con tripsina fueron analizadas por electroforesis en gel SDS en gradiente $12-24 \%$, revelado mediante Western Blot contra ApoA-I y comparando con el control Wt. L60R exhibe un fragmento proteolítico de un tamaño $20 \mathrm{kDa}$ que se hace evidente a partir de los 15 min de comenzada la proteólisis. 


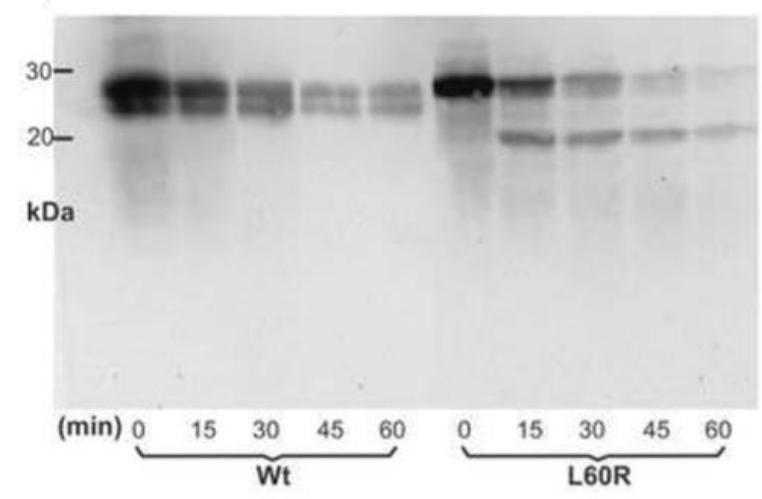

Figura 5.8: Caracterización del producto de tripsinólisis. Western Blot de la tripsinización de ApoA-I Wt y L60R en un gel SDS PAGE en gradiente 12-24\% realizada en intervalos de 15 min durante $1 \mathrm{~h}$. Como marcador de peso molecular se empleó SDS LMW.

\subsection{DICROISMO CIRCULAR}

Para obtener información acerca de la estructura secundaria, se analizó el espectro de Dicroísmo Circular (CD) en el UV lejano que comprende un barrido desde 180 a $250 \mathrm{~nm}$. Los tres espectros mostraron un comportamiento similar a una proteína con alto contenido en $\alpha$ hélice (dobles mínimos a 222 y $208 \mathrm{~nm}$ y un máximo a $191 \mathrm{~nm}$ ). Sin embargo, mientras que el espectro de W50R fue similar al del $\mathrm{Wt}$, el L60R evidenció una pérdida relativa de $\alpha$ hélice del $7 \%$ (Figura 5.9).

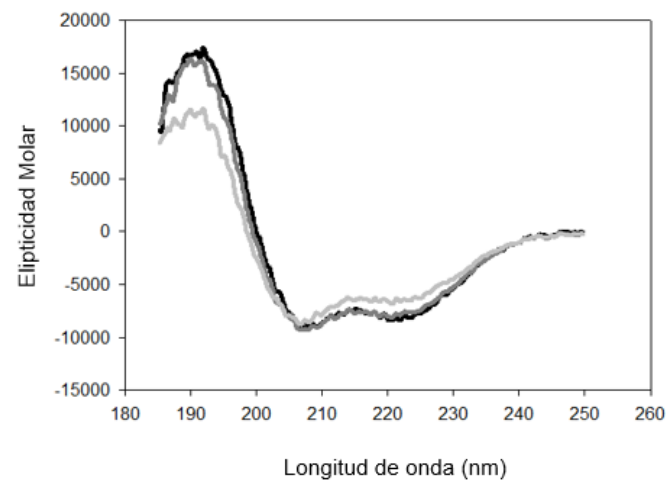

Figura 5.9 CD en el UV lejano. Wt (negro), W50R (gris oscuro) y L60R (gris claro). Las proteínas fueron diluidas en buffer fosfato $\mathrm{pH} 7.4$ a una concentración final de $0.2 \mathrm{mg} / \mathrm{ml}$ midiéndose la elipticidad molar en función de la longitud de onda 
A fin de obtener información relativa sobre la estructura terciaria, se determinó el espectro de CD en el UV cercano; esto comprende un barrido espectral de 250-320 nm que brinda una "huella digital" de cada proteína y censa especialmente los aminoácidos aromáticos. Como muestra la Figura $5.10 \mathrm{se}$ puede apreciar leves diferencias estructurales de las variantes de ApoA-I respecto a Wt debido a una sutil diferencia en la distribución de aminoácidos aromáticos en la zona de 250 a $280 \mathrm{~nm}$.

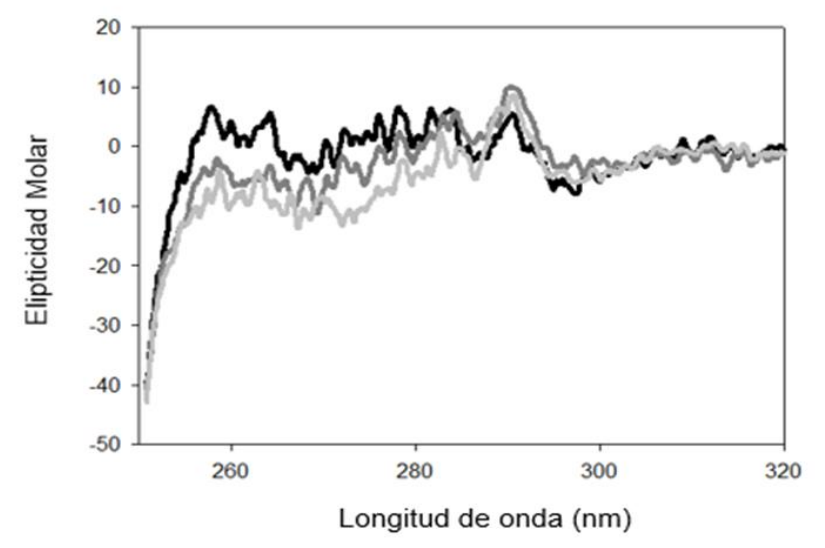

Figura 5.10. Espectro de CD en el UV cercano. Wt (negro), W50R (gris oscuro) y L60R (gris claro). Las proteínas fueron llevadas a una concentración final de $1.0,1.5$ y $1.5 \mathrm{mg} / \mathrm{ml}$ en buffer fosfato $\mathrm{pH} 7.4$ respectivamente; midiéndose la elipticidad molar en función de la longitud de onda.

\subsection{ESTUDIO DEL EQUILIBRO DÍMERO-MONOMERO DE APOA-I Y SUS}

\section{VARIANTES}

La cromatografía de exclusión molecular permite indagar sobre la conformación y estado de oligomerización proteica, dado que permite discernir tamaños dentro de un rango elegido en base al tiempo de retención cuando la misma es eluida a través de una matriz. Es conocido que la ApoA-I libre de lípidos tiende a la auto asociación para la formación de dímeros y agregados mayores dependiendo entre otros factores de la concentración (Davidson W 1996). A medida que aumenta el tamaño de la proteína eluida, ésta es menos retenida en la columna de exclusión molecular respecto a su conformación monomérica. En este ensayo se comparó el perfil de elución de las variantes en estudio respecto 
a la Wt en idénticas condiciones, diluidas recientemente en buffer fosfato $\mathrm{pH}$ 7.4. A fin de asignar el peso molecular a los picos detectados, se corrieron en igual buffer y flujo proteínas de peso molecular conocido (Figura $5.11 \mathrm{~A}$ ). El perfil de elución de las variantes de ApoA-I está graficado en la Figura 5.11 B. El Wt eluyó como un pico predominante a los 19 min y se corresponde con un peso molecular de $57 \mathrm{kDa}$. Se observó también otro pico minoritario a los $26 \mathrm{~min}$, el cual se correlaciona con un peso molecular de $27 \mathrm{kDa}$, los que fueron asignados a dímero y monómero respectivamente. El peso relativo de ambas fracciones fue determinado usando el analizador Originpro8 (análisis del área bajo la curva con fiteo a dos áreas). En la Figura $5.11 \mathrm{~B}$ se observa que ambas mutantes amiloidogénicas eluyeron mayoritariamente como dímero; si bien esta conformación predominó en la muestra correspondiente al $\mathrm{Wt}$, la fracción de monómero representó alrededor del $20 \%$ de la proteína total.

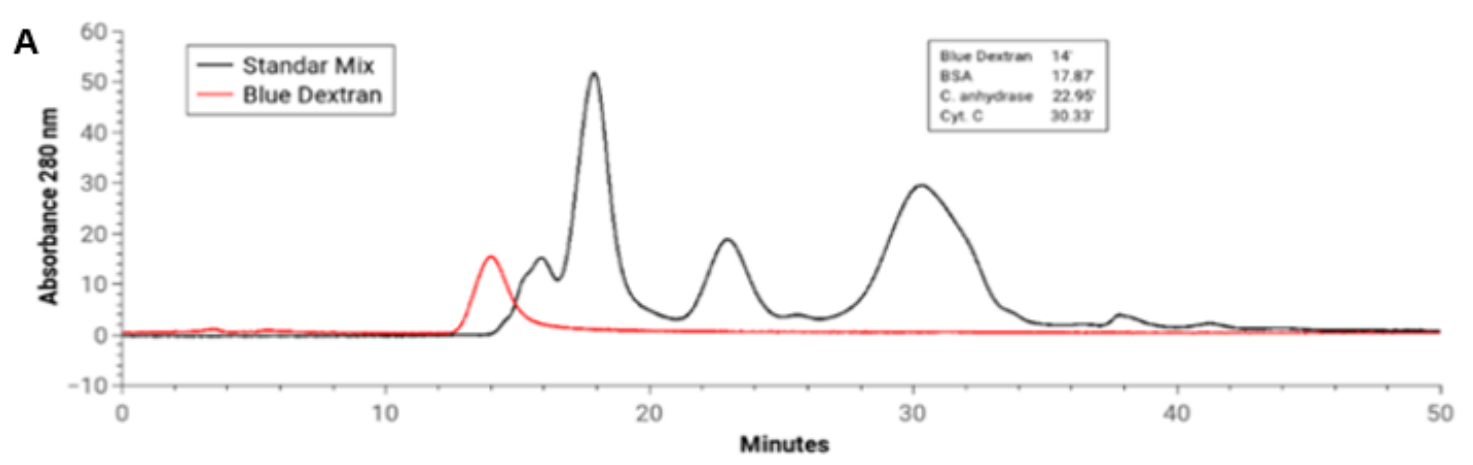

B

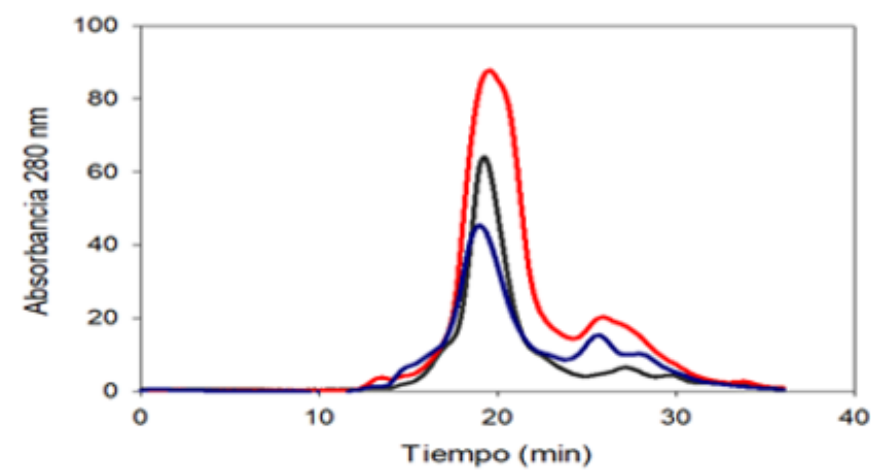

Figura 5.11: Caracterización del estado de oligomerización de variantes. A) las proteínas de peso molecular conocido Albúmina Bovina (MW 66 kDa), Anhidrasa carbónica (MW 29 kDa) y Citocromo $\mathrm{C}(12 \mathrm{kDa}$ ) fueron resuspendidas en buffer fosfato $\mathrm{pH} 7.4$ y eluidas a un flujo de 0.5 $\mathrm{ml} / \mathrm{min}$ a través de una columna Superdex $75 \mathrm{GL}$ (perfil en negro). El volumen muerto (Vo) fue estimado por la elusión de azul dextrán en las mismas condiciones (rojo). Los tiempos relativos 
de elusión respecto al Vo fueron usados para determinar el peso molecular de las proteínas en estudio. B) 250 ug de las proteínas en 500 ul de buffer fosfato a pH 7.4 fueron eluidas en exactas condiciones. Wt en rojo, W50R azul y L60R gris oscuro

\subsection{ENSAYOS DE AGREGACIÓN DE APOA-I}

\subsubsection{Tioflavina T (ThT)}

A fin de comparar la tendencia en la formación de agregados de tipo amiloide, Wt y ambas variantes se incubaron a pH 7.4 y 5.0 durante $48 \mathrm{~h}$ a $37^{\circ} \mathrm{C}$ en agitación constante a $0.2 \mathrm{mg} / \mathrm{ml}$ en buffer citrato fosfato. La formación de complejos de mayor tamaño y de características pro amiloides fue estimada mediante dispersión de luz y fluorescencia asociada a tioflavina respectivamente.
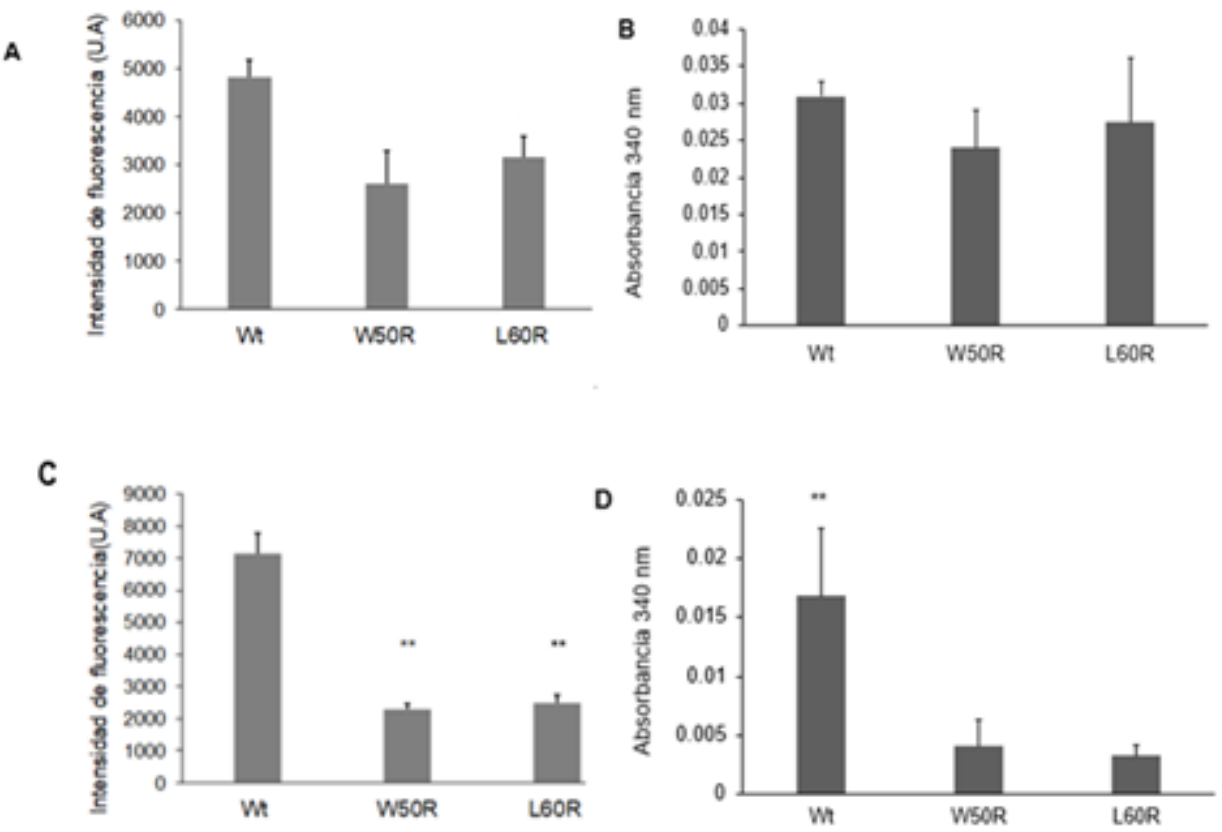

Figura 5.12: Caracterización de agregados de variantes incubados a baja concentración. Las proteínas $(0.2 \mathrm{mg} / \mathrm{ml})$ fueron incubadas por $48 \mathrm{hs}$ a $37^{\circ} \mathrm{C}$ a pH 7.4 (A y B), o a pH 5.0 (C y D). La fluorescencia relativa asociada a ThT ( $A$ y $C$ ) se cuantificó en lector de placa (con excitación a $430 \mathrm{~nm}$ y emisión a $480 \mathrm{~nm}$ ). La absorbancia se cuantificó en el mismo equipo con filtro a $340 \mathrm{~nm}(B$ y $D)$ Las barras corresponden al promedio \pm desviación estándar. Las diferencias significativas estadísticamente en las condiciones experimentales fueron evaluadas por test de Student. ${ }^{*} y{ }^{* *}$ denotan una diferencia con respecto al Wt a $p<0.05$ y $p<0.001$ respectivamente. 
Las mutantes no mostraron un incremento de fluorescencia de ThT en condiciones fisiológicas y a $\mathrm{pH}$ ácido las variantes de ApoA-I muestran una disminución del rendimiento cuántico de la misma respecto a la secuencia nativa, esto demuestra que per se las proteínas no exhiben una tendencia de agregación significativa en las condiciones analizadas. Dado que la agregación puede ser favorecida a mayores concentraciones y tiempos de incubación, analizamos a Wt y sus variantes incubando durante 7 días a $\mathrm{pH}$ fisiológico a una concentración de $0.6 \mathrm{mg} / \mathrm{ml}$ a $37^{\circ} \mathrm{C}$ en agitación. Previo a la determinación de fluorescencia, las proteínas se diluyeron en el mismo buffer a una concentración final de 0.2 $\mathrm{mg} / \mathrm{ml}$. Como control del ensayo se midió la fluorescencia de la sonda en presencia de proteínas frescas a la misma concentración

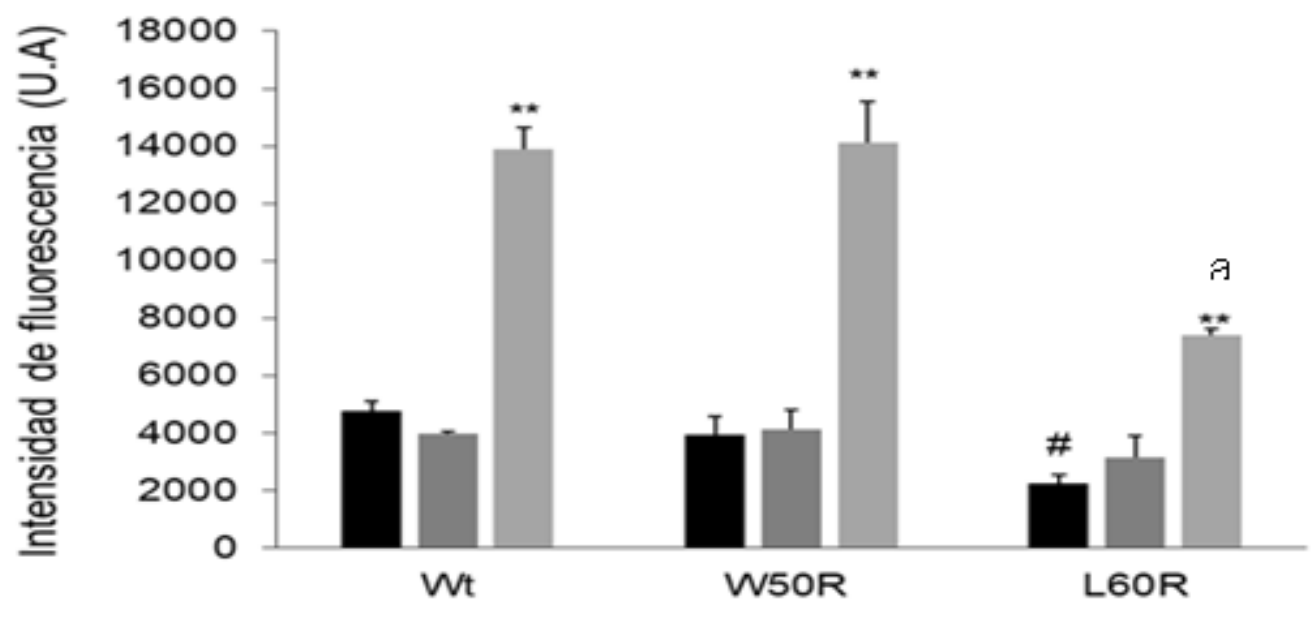

Figura 5.13. Fluorescencia de ThT de Wt, W50R y L60R a pH 7.4. Las variantes se diluyeron a una concentración final de $0.2 \mathrm{mg} / \mathrm{ml}$ y luego fueron incubadas por 0 (negro) y 2 días a $37^{\circ} \mathrm{C}$ (gris oscuro). Simultáneamente proteínas a $0.6 \mathrm{mg}$ fueron incubadas 7 días a $37^{\circ} \mathrm{C}$ llevadas a $0.2 \mathrm{mg} / \mathrm{ml}$ previo a la medición (gris claro). La ThT fue agregada en relación molar 1:1. La fluorescencia a $480 \mathrm{~nm}$ se cuantificó en lector de placa (excitación a $430 \mathrm{~nm}$ ). Las barras corresponden al promedio \pm desviación estándar. Las diferencias significativas en las condiciones experimentales fueron evaluadas por test de Student. El símbolo \# denota una diferencia significativa a $\mathrm{t}=0$ respecto a $\mathrm{Wt}$ con $\mathrm{p}<0.001$; ${ }^{* *}$ denota una diferencia significativa respecto a la misma proteína a $t=0$ con $p<0.001$. a denota diferencia significativa respecto $\mathrm{Wt}$ a los 7 días de incubación con $p<0.001$.

Como muestra la Figura 5.13, la intensidad de fluorescencia se incrementa en esas condiciones de mayor concentración y tiempos de incubación. Sin embargo 
la variante L60R exhibe un rendimiento cuántico de ThT menor a las otras dos proteínas analizadas.

\subsubsection{VISUALIZACIÓN DE LOS COMPLEJOS AMILOIDES}

A fin de caracterizar la morfología de los agregados, las muestras de $\mathrm{Wt}$, W50R y L60R incubadas en las condiciones anteriores (7 días a $0.6 \mathrm{mg} / \mathrm{ml}$ y $\mathrm{pH}$ 7.4) se observaron por microscopía. La microscopía electrónica de transmisión (mediante la tinción negativa con ácido fosfotúngstico) permitió obtener una observación "panorámica" de las muestras. La comparación relativa indica la presencia de estructuras tipo oligómeros y agregados amorfos dispersos en la grilla (flechas blancas) y algunas protofibrillas aisladas, de un diámetro aproximado entre 5 y $15 \mathrm{~nm}$ (flechas negras) para las tres variantes. La comparación cualitativa sugiere un aparente mayor rendimiento de agregados para L60R (Figura 5.14).

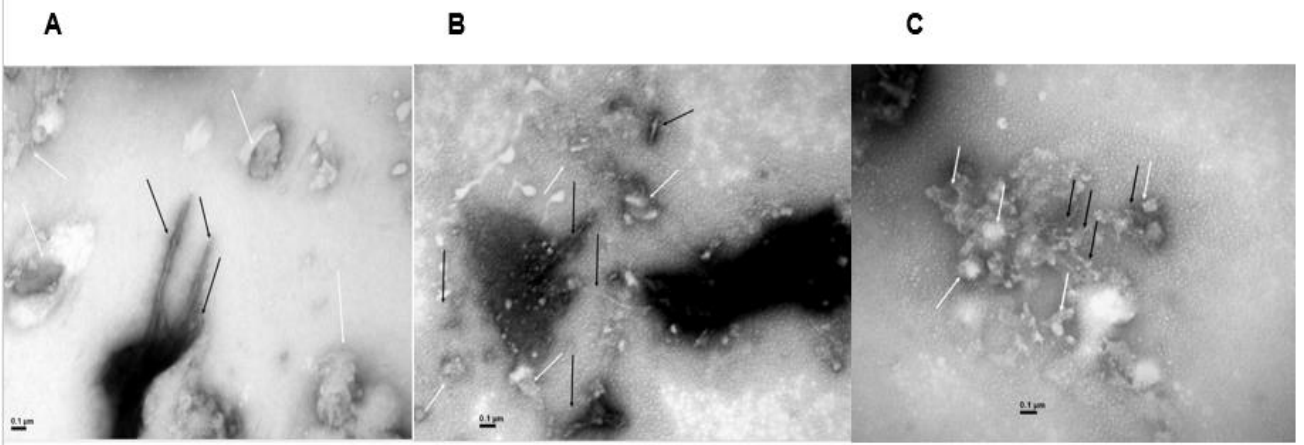

Figura 5.14. Microscopía MET. A) Wt, B) W50R y C) L60R. Las proteínas se incubaron 7 días a una concentración final de $0.6 \mathrm{mg} / \mathrm{ml}$. La barra negra en cada figura indica la escala de observación. Flechas blancas indican oligómeros y flechas negras indican protofibras

Dada la diferencia observada en el plegamiento estructural de L60R nos avocamos a obtener mayor información estructural de esta variante, empleando microscopía de fuerza atómica (AFM). Mediante un principio diferente (censa topología de la superficie) se obtiene gran resolución de la morfología y cuantificación más aproximada de la altura de los agregados. Las muestras se incubaron en las condiciones descritas arriba. La Figura 5.15 A muestra que, en concordancia con los datos de MET, el Wt está representado por una distribución 
homogénea de oligómeros de una altura aproximada de 5-15 nm, y protofibras aisladas de la misma altura. En cambio en la muestra de L60R se observó un elevado índice de agregación, lo que requirió una dilución de la muestra de 1/10 para poder visualizar mejor la morfología. El análisis topográfico de la muestra permitió además observar una distribución morfológicamente heterogénea. Además de estructuras elongadas (Figura $5.15 \mathrm{~B}$ ), se observaron estructuras tipo gel (C y D flechas negras) y fibras de conformación definida (D flecha blanca). En algunas observaciones se detectaron fibras agregadas tipo placas (C flechas blancas e inserto), el espesor aproximado de todas las conformaciones fue similar (5-15 nm).
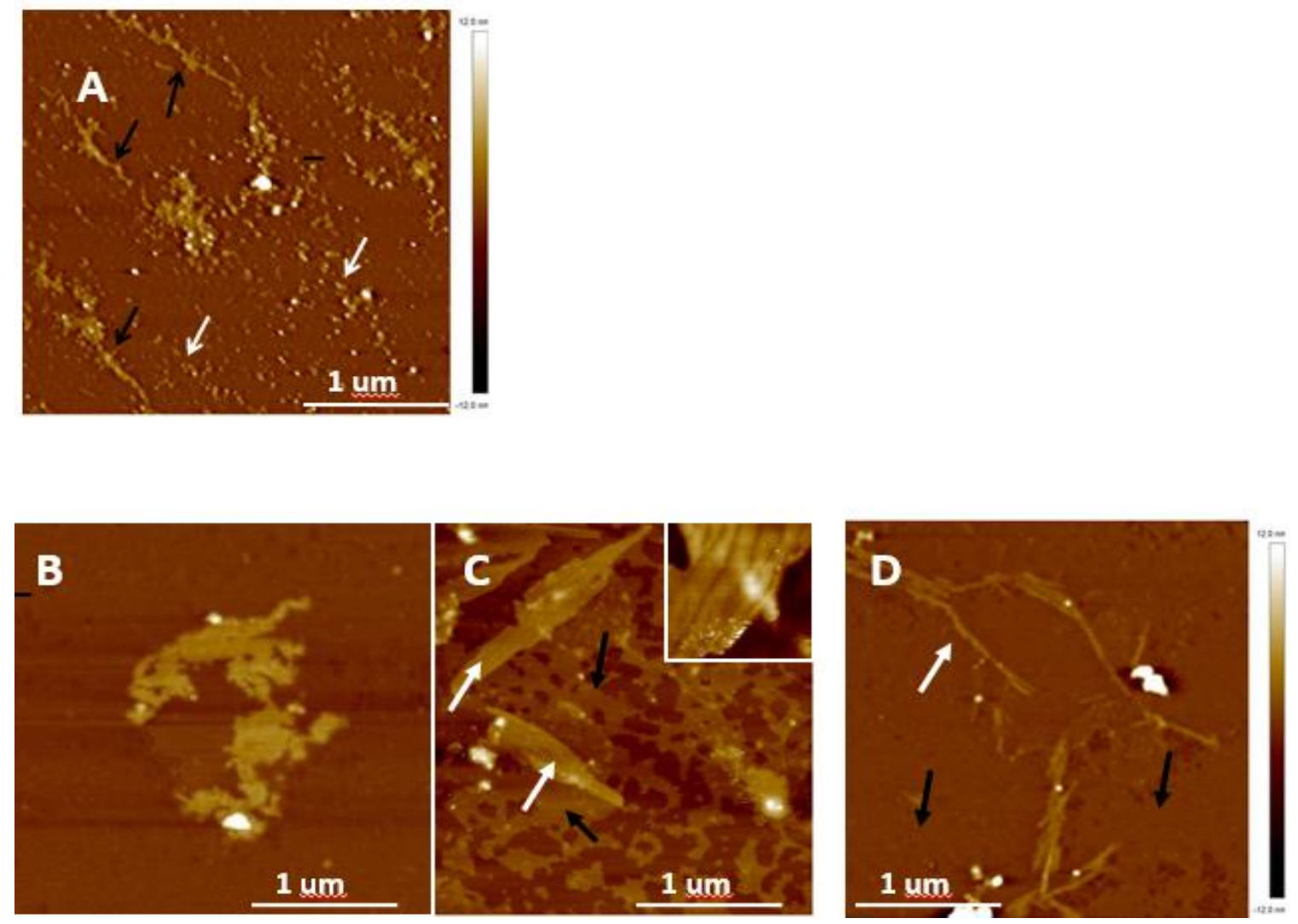

Figura 5.15. Imágenes de AFM. Wt y L60R fueron incubadas a $0.6 \mathrm{mg} / \mathrm{ml}$ durante 7 días a $\mathrm{pH}$ y temperatura fisiológica. A) Wt presenta oligómeros (flechas blancas) y estructuras elongadas (flechas negras) B, C y D) Conformaciones de L60R. B) Protofibras C) Estructura tipo gel (flechas negras) y fibras en forma de placa (flecha blanca e inserto) D) Fibras amiloides maduras (flecha blanca). Sobre la derecha de la Figura A y D se muestra la escala de color asociada a la altura de la muestra.

\subsubsection{EFECTO DE LA UREA SOBRE LA AGREGACION}


El hallazgo de las variantes W50R y L60R como agregados amiloides renales en pacientes y con distinta localización (básicamente glomerular y túbulo intersticial respectivamente) (Tougaard BG 2016), sugiere la hipótesis que algún evento local puede favorecer su depósito selectivo. En ese marco, es conocido que a nivel de la curvatura del asa de Henle de la nefrona, las concentraciones fisiológicas de urea en el intersticio renal pueden llegar a 0.6 M (Berne 2009). Por tanto resultó interesante analizar la probable participación de este agente en la agregación de estas variantes. Con este fin, las variantes de ApoA-I fueron incubadas en ausencia o presencia de urea. Las proteínas se incubaron a $\mathrm{pH}$ ácido y fisiológico a una concentración final de $0.2 \mathrm{mg} / \mathrm{ml}$ durante $72 \mathrm{~h}$ en presencia y ausencia de $0.6 \mathrm{M}$ de urea y luego se midió intensidad de la sonda ThT en relación molar 1:1.
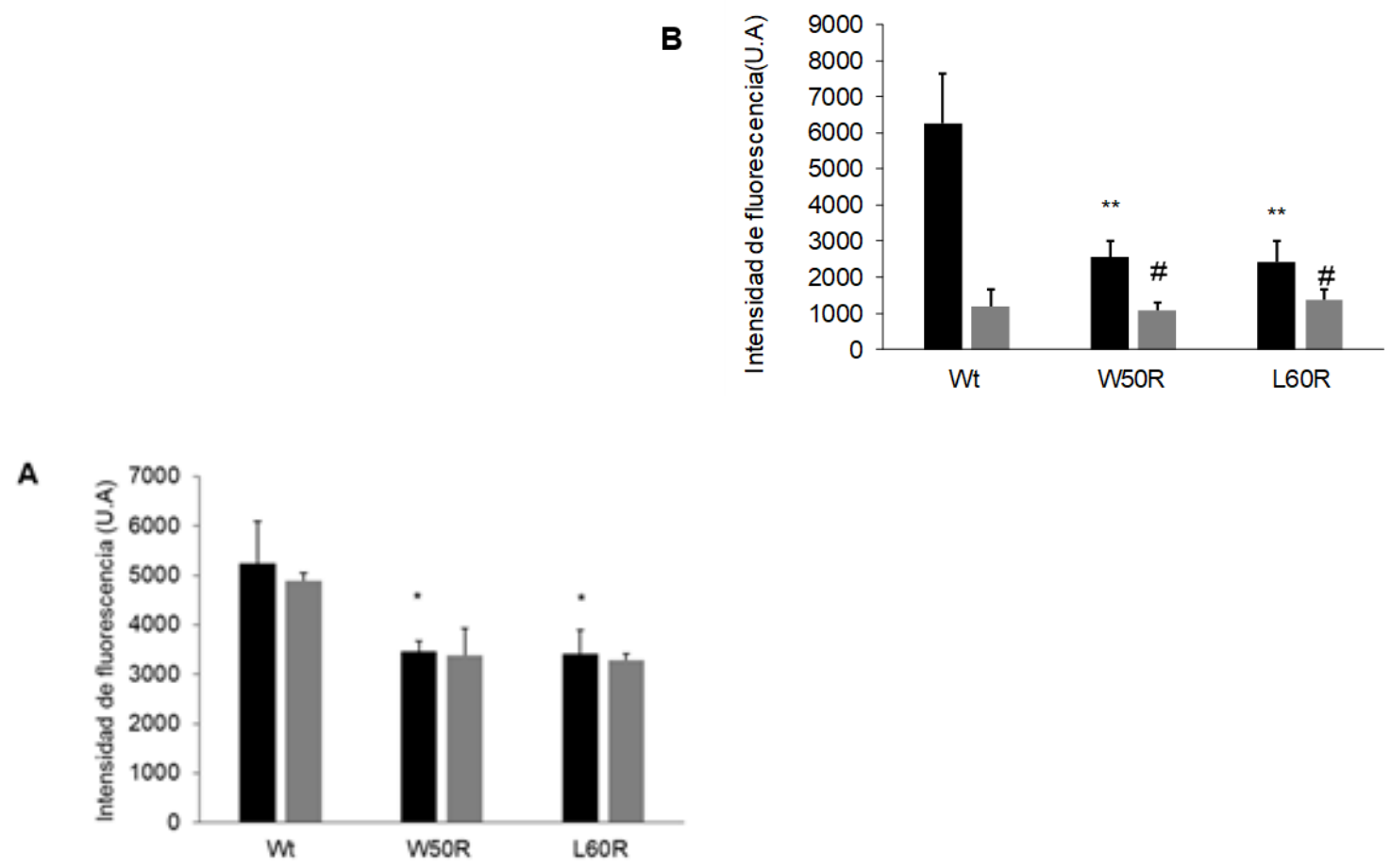

Figura 5.16: Fluorescencia de ThT en presencia de $\mathbf{0 . 6} \mathbf{M}$ de urea. A) $\mathrm{pH}$ 7.4; B) pH 5.0. Las proteínas se incubaron a $0.2 \mathrm{mg} / \mathrm{ml}$ durante $72 \mathrm{~h}$ en ausencia de urea (negro) y presencia de urea (gris). Los símbolos * $\mathrm{y}{ }^{* *}$ denotan diferencias significativas de Wt respecto a las dos variantes en ausencia de urea usando el test de Student con $p<0.05$ y $p<0.001$ respectivamente. \# representa diferencia de cada variante respecto a su señal en ausencia de urea con $p<0.001$. 
Los resultados sugieren que la urea no produce incremento del rendimiento cuántico de ThT de las variantes en las condiciones estudiadas y a $\mathrm{pH}$ ácido pareciera disminuir aún más la señal de la sonda.

\subsubsection{UNIÓN A LIGANDOS CELULARES}

\subsubsection{HEPARINA}

La heparina es estudiada por ser un modelo de GAG, los cuales se encuentran formando parte de un complejo arreglo de proteínas en la matriz extracelular, cumpliendo funciones como regulador del crecimiento celulares, retención de lipoproteínas etc (lannuzzi C 2015). Los GAGs tienen un elevado grado de sulfatación y por ello poseen carga negativa. Dado que las mutantes analizadas tienen un reemplazo de un aminoácido neutro por otro positivo, podría esperarse una mayor interacción de las mismas con la matriz, favoreciendo su retención. El estudio de unión a GAGs es interesante además, dado que se ha observado que la interacción de los mismos con proteínas pro amiloidogénicas podría resultar tanto en el aumento de agregación como en su inhibición (Rosú SA 2015, Ramella NA 2011). A fin de estudiar el probable efecto de los GAGs sobre la formación de agregados amiloides de ApoA-I, Wt y sus variantes naturales (a una concentración de $0.2 \mathrm{mg} / \mathrm{ml}$ ) se incubaron durante $48 \mathrm{~h}$ a $37^{\circ} \mathrm{C}$ en presencia de heparina en una relación molar 2:1 ligando:proteína a los pHs mencionados y posteriormente se ensayó la unión a ThT. Los resultados se muestran en la Figura 5.17. 

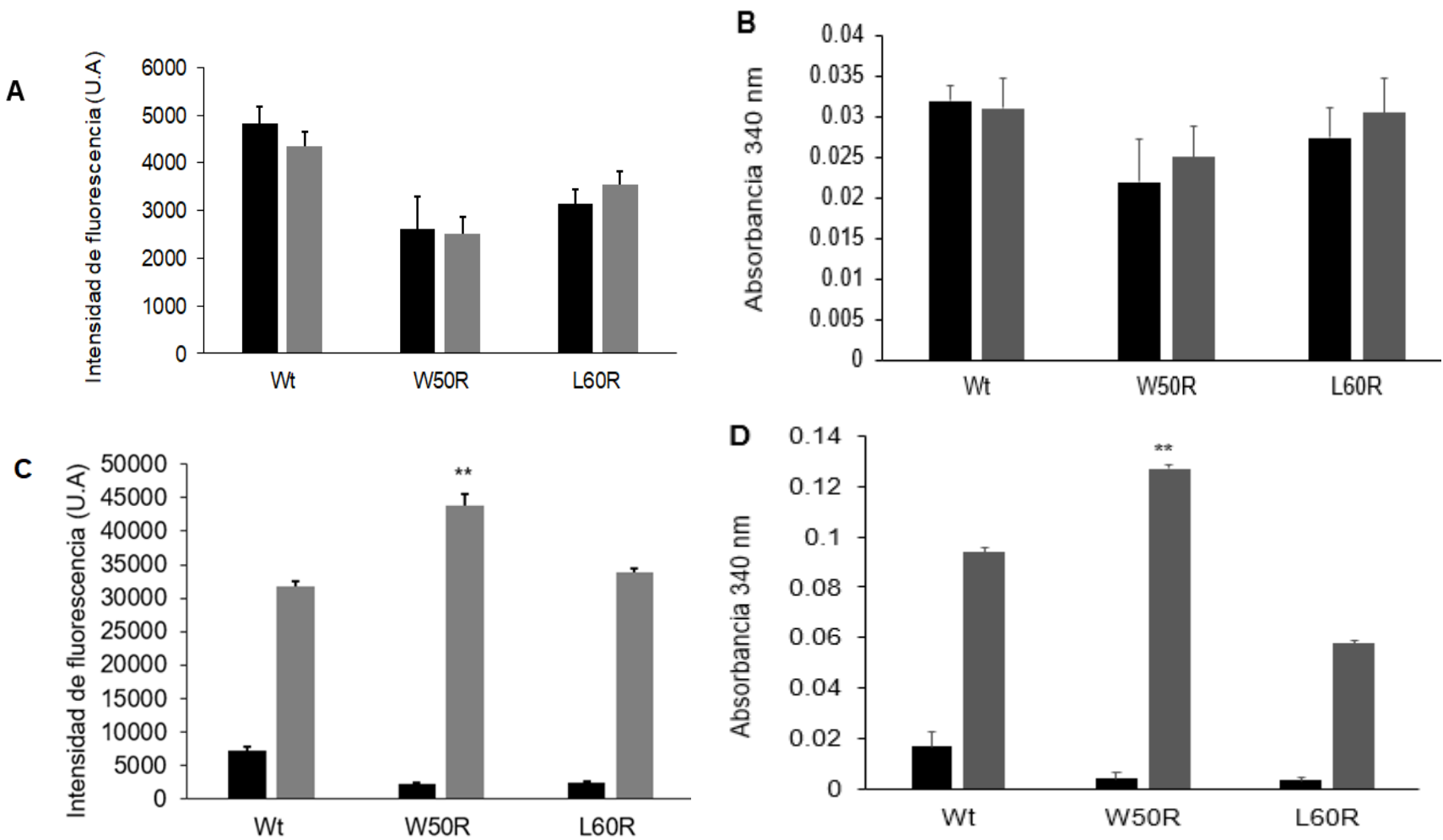

Figura 5.17. Efecto de la heparina sobre la agregación proteica. Las proteínas se incubaron a $0.2 \mathrm{mg} / \mathrm{ml}$ en buffer citrato-fosfato a pH 7.4 ( $\mathrm{A}$ y $B$ ) o pH 5.0 ( $C$ y D) en ausencia (negro) y presencia (gris) de heparina en relación molar 2:1 heparina:proteína. Fluorescencia de ThT (A y C) o absorbancia ( $B$ y D) se determinaron como fue mencionado en la Figura 5.12. ${ }^{* *}$ denota diferencias significativas de W50R y L60R respecto a Wt en presencia de heparina usando el test de Student con $p>0.001$

Como fue demostrado previamente por nuestro grupo, la Wt no muestra indicios de unión a heparina a pH fisiológico pero sí cuando el pH desciende (Ramella NA 2011, Rosú SA 2015), formando estructura tipo amiloide que unen ThT. La Figura 5.17 indica que L60R incrementa la señal de la sonda ThT en condiciones ácidas con presencia del ligando celular en una magnitud similar a Wt. En cambio W50R unido a heparina, genera un aumento significativo del rendimiento cuántico de ThT y de dispersión de luz respecto al Wt, indicando así una tendencia de agregación significativa de esta variante frente al ligando.

\subsubsection{SDS}


El dodecil sulfato de sodio (SDS) es un compuesto anfipático (cadena acílica apolar y cabeza polar negativa) que fue usado como modelo de lípido negativo imitando algunas características de las membranas biológicas (Giehm 2010); además, se ha descrito que provoca la formación de fibrillas a partir de diferentes péptidos y proteínas si se utiliza por debajo de la concentración micelar crítica (CMC). A fin de indagar si estos ligandos pueden incrementar la agregación proteica, las variantes de ApoA-I se incubaron con $0.2 \mathrm{mM}$ de SDS durante $48 \mathrm{~h} 37^{\circ} \mathrm{C}$ (la CMC calculada en estas condiciones fue de $0.7 \mathrm{mM}$, en buffer citrato fosfato) (Rosú SA 2015).

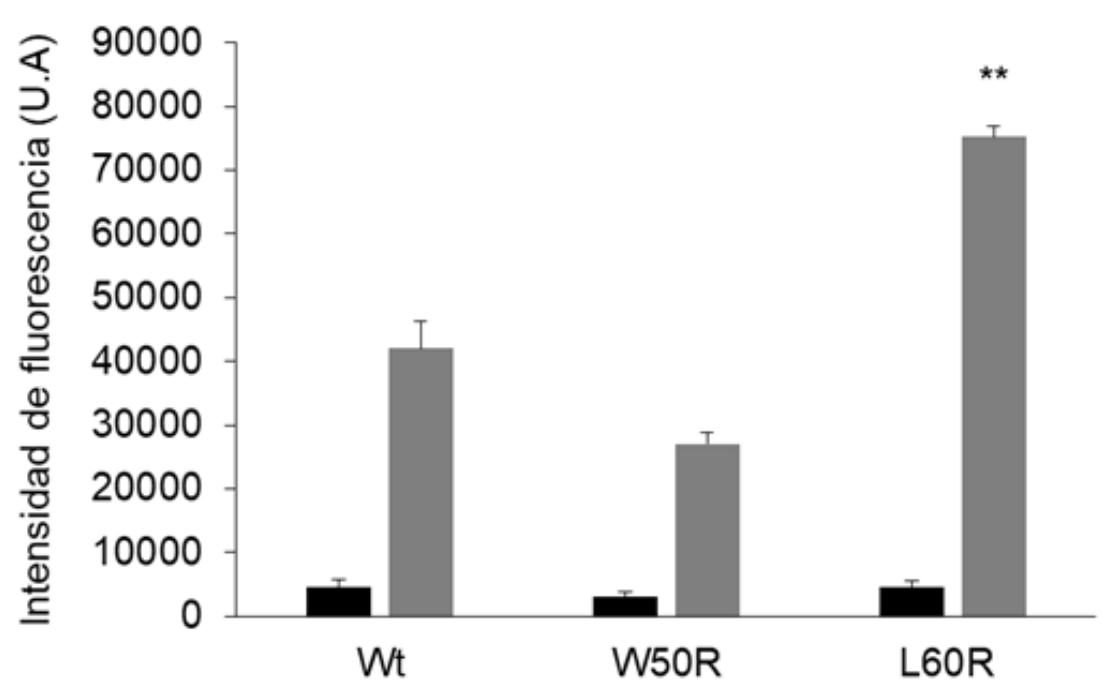

Figura 5.18. Fluorescencia de ThT en presencia de $0.2 \mathrm{mM}$ de SDS. $0.2 \mathrm{mg} / \mathrm{ml}$ de proteína se incubaron por $48 \mathrm{~h}$ en ausencia (negro) y presencia (gris) del ligando. ${ }^{* *}$ denota diferencias significativas respecto del Wt con $p>0.001$ usando test de Student.

Como ya ha sido demostrado previamente por nuestro grupo, el SDS interacciona con el Wt aumentando la fluorescencia de ThT (Rosú 2015); si bien el mismo comportamiento es observado para ambos mutantes, la intensidad de fluorescencia ThT de L60R en presencia de SDS es mayor (Figura 5.18). 
Para indagar sobre la naturaleza de la interacción con este ligando, Wt y L60R se titularon en presencia de concentraciones crecientes de SDS, registrando la fluorescencia intrínseca de ambas proteínas (Figura 5.19). En ambos se puede ver que existe un corrimiento de $\mathrm{W}$ a menores longitudes de onda, lo que indica una organización estructural de los residuos hacia entornos no polares.
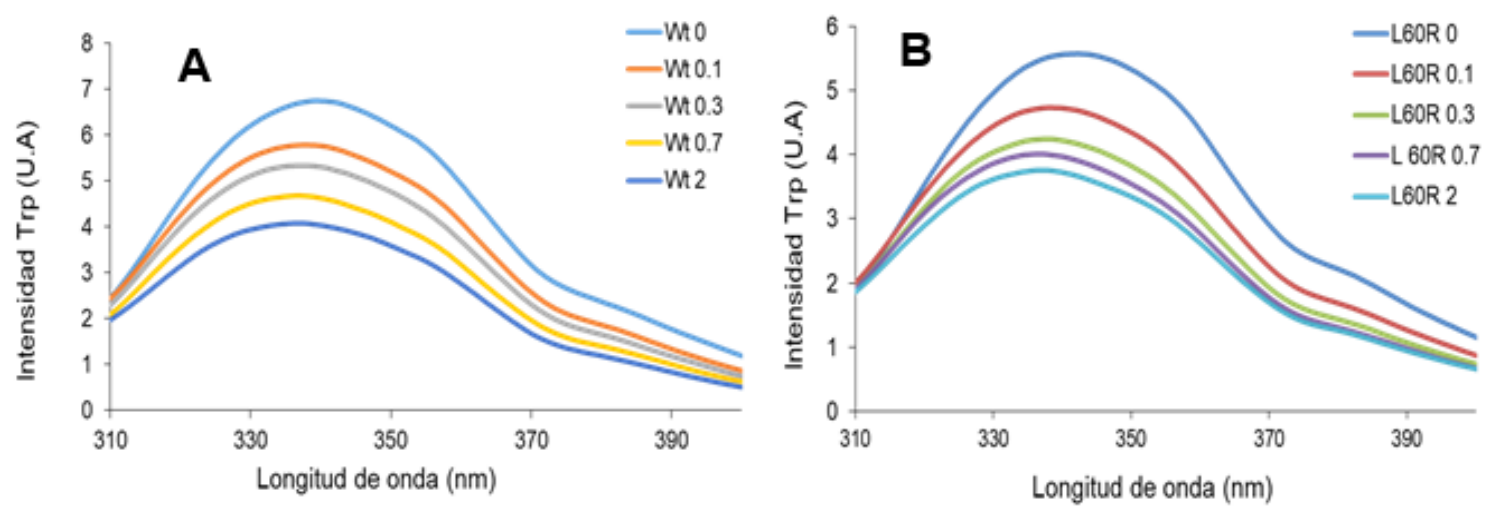

Figura 5.19. Curva de titulación con SDS mediante fluorescencia intrínseca de $\mathbf{W}$. A) Wt B) L60R. Los espectros de emisión fueron registrados excitando a $280 \mathrm{~nm}$ con emisión en el rango $310-400 \mathrm{~nm}$

Luego analizamos la fluorescencia asociada a Bis-ANS en las distintas condiciones. Los máximos de fluorescencia de la sonda (Tabla 5.3) indican un entorno diferente de la sonda a las distintas concentraciones de SDS.

Tabla 5.3. Conformación de variantes frente a SDS. Proteínas llevadas a $0.1 \mathrm{mg} / \mathrm{ml}$ fueron incubadas con distintas concentraciones de SDS. Luego del agregado de Bis-ANS, el espectro de fluorescencia se registró con excitación a $395 \mathrm{~nm}$ registrando la longitud de onda a la que ocurre el máximo de emisión.

\begin{tabular}{|c|c|c|c|}
\hline \multicolumn{2}{|c|}{ Wt } & \multicolumn{2}{c|}{ L60R } \\
\hline SDS [mM ] & $\Lambda(\mathrm{nm})$ & SDS [mM ] & $\lambda(\mathrm{nm})$ \\
\hline 0 & $481+/-0.5$ & 0 & $482+/-0.5$ \\
\hline 0.1 & $482+/-0.9$ & 0.1 & $484+/+0.6$ \\
\hline 0.3 & $486+/-1.0$ & 0.3 & $485+/-0.6$ \\
\hline 0.7 & $488+/-0.5$ & 0.7 & $487+/-1.0$ \\
\hline 2 & $495+/-1.0$ & 2 & $494+/-1.5$ \\
\hline
\end{tabular}


Finalmente analizamos a tendencia a formar estructuras pro amiloides mediante el análisis de la unión a ThT. La Figura 5.20, indica un incremento de la señal ThT con la interacción ApoA-I- ligando anfipático hasta una concentración cercana a la CMC. Para concentraciones superiores del ligando la fluorescencia de ThT desciende. Este efecto es similar pero de mayor rendimiento para L60R respecto a Wt. Estos parámetros indican un cambio conformacional de las proteínas asociado a la interacción con este ligando.

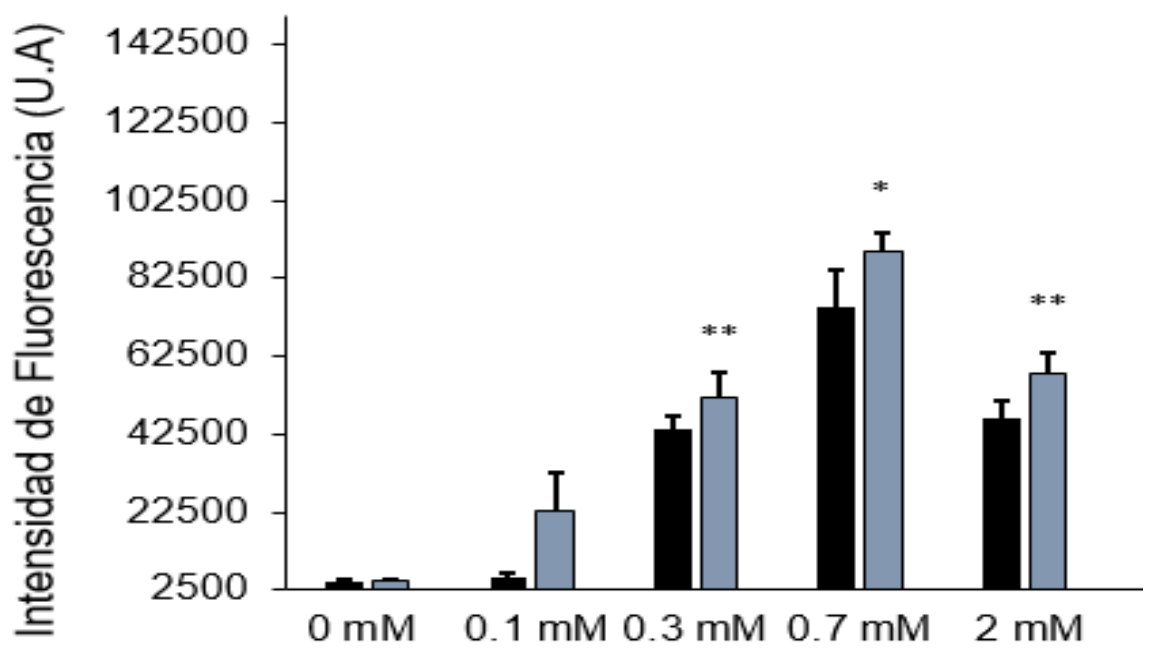

Figura 5.20. Fluorescencia de ThT de Wt (negro) y L60R (celeste) en presencia de diversas concentraciones de SDS. $(0,0.1,0.3,0.7$ y $2 \mathrm{mM})$ a $48 \mathrm{hs}$ de incubación a $37^{\circ} \mathrm{C}$. ${ }^{*}{ }^{*}{ }^{*}$ denotan diferencias significativas de L60R respecto a Wt en cada concentración mencionada con $p$ $<0.005$ y $p<0.05$ respectivamente mediante test de Student.

\subsection{UNIÓN DE L60R A LÍPIDOS}

Una función reconocida y estudiada tradicionalmente de la ApoA-I que es vital a su rol ateroprotector es la habilidad de solubilizar lípidos. El ensayo de micelización espontánea cuando la proteína se incuba con fosfolípidos multilamelares a su temperatura de transición ha sido ampliamente utilizado, demostrando un aclaramiento rápido y eficiente a medida que los liposomas son consumidos para rendir complejos lipoproteicos. Se ha demostrado también que la variante W50R no pierde esta función (Das M 2014). 
A fin de analizar si el reemplazo de la Leu en posición 60 induce una disminución en esta función, Wt y L60R se incubaron con vesículas multilamelares de DMPC a $24^{\circ} \mathrm{C}$ (temperatura de transición lipídica) y se registró absorbancia a $340 \mathrm{~nm}$ en función del tiempo. Como la Figura 5.21 indica, L60R muestra un aclaramiento de lípidos ligeramente más eficiente que $\mathrm{Wt}$, lo que indica una función conservada (o ligeramente aumentada) en la unión a lípidos de esta variante.

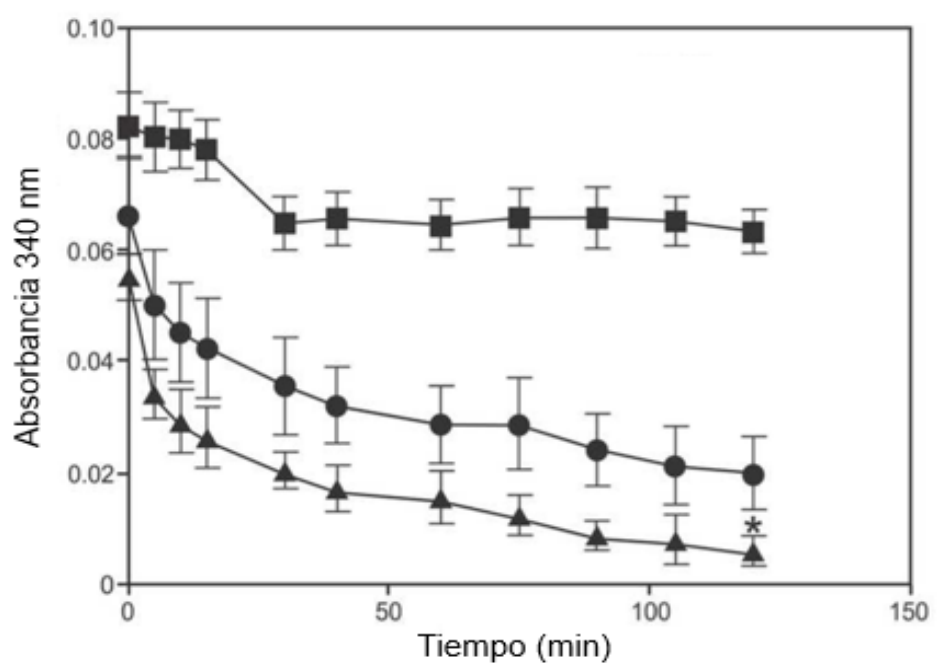

Figura 5.21: Caracterización de formación espontánea de complejos Lípido: proteína. Liposomas multilamelares de DMPC fueron incubados a $24^{\circ} \mathrm{C}$ y se midió absorbancia a $340 \mathrm{~nm}$ sin proteína (cuadrados), con Wt (círculos) o L60R (triángulos), relación molar lípido a proteína $80: 1 .{ }^{*}$ denota $p>0.05$ por test de Student respecto al mismo tiempo en Wt.

\subsection{RESPUESTA INFLAMATORIA MEDIADA POR APOA-I Y SUS VARIANTES}

Una hipótesis atractiva a considerar, sugiere que pequeños cambios conformacionales pueden inducir la generación de una estructura proteica que sea reconocida como inductor de una respuesta inflamatoria innata (Rojo-León $V$ 2012). A fin de conocer si las variantes de ApoA-I pueden per se iniciar una respuesta pro inflamatoria, se ensayó la producción de IL-1 $\beta$ y TNF- $\alpha$ a partir de la activación de un modelo de macrófagos. Se llevó a cabo la diferenciación celular de monocitos a macrófagos activos mediante el uso de PMA durante 48 $\mathrm{h}$ y luego se incubaron las células por $3 \mathrm{~h}$ a $37^{\circ} \mathrm{C}$ con diversos tratamientos 
realizados por triplicado: polimixina B y LPS + polimixina B (controles negativos), LPS (control positivo) y Wt, W50R, L60R en presencia del antibiótico para evitar respuesta inmune inespecífica. Posteriormente se extrajo los sobrenadantes para medir la producción de citoquinas pro inflamatorias mediante el kit ELISA (Figura 5.22).

A

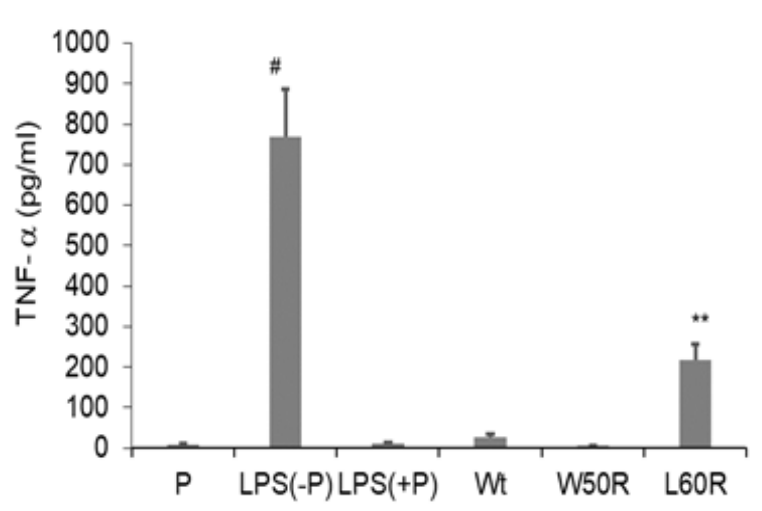

B

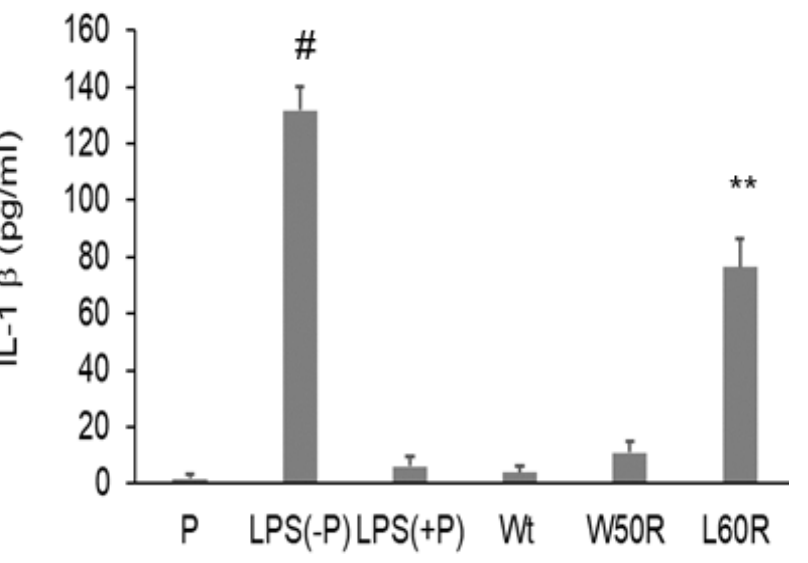

Figura 5.22. Respuesta inflamatoria de ApoA-I y sus variantes. Liberación de A) TNF $\alpha$ o B) IL-1 $\beta$ a partir de células THP-1 diferenciadas a macrófagos en presencia o ausencia de $1 \mu \mathrm{g} / \mathrm{ml}$ ó $0.5 \mu \mathrm{g} / \mathrm{ml}$ respectivamente de las variantes durante $3 \mathrm{~h}$. La liberación se detectó en el sobrenadante. \# denota diferencias significativas respecto del control negativo del LPS y $y$ ** del L60R respecto a Wt con $p>0.001$ mediante el test de Student.

Se puede afirmar que la variante L60R (pero no W50R) induce liberación de TNF $\alpha$ e IL-1 $\beta$ a $3 \mathrm{~h}$ de la exposición ante los macrófagos activados sugiriendo asi la activación de la respuesta inflamatoria por parte de la mutante.

\section{DISCUSIÓN}


La ApoA-I posee estructura terciaria laxa, la cual le permite llevar a cabo funciones complejas como la interacción con lípidos y con receptores de membrana como ABCA1 y SRB1 en los pasos metabólicos involucrados en el TRC (Obici L 2006, Bibow S 2017). Cualquier alteración en su conformación, ya sea por una mutación hereditaria o debida a eventos del microambiente, podría inducir una disminución en su eficiencia para cumplimentar éstas y otras delicadas funciones. Más aún, corrimientos del delicado equilibrio estructurafunción podrían desencadenar la formación de depósitos amiloides órganoespecíficos, como se describe anteriormente. En este trabajo propongo profundizar en el conocimiento de la consecuencia del reemplazo de un aminoácido en la agregación patológica de las variantes $\mathrm{N}$ terminales de ApoA-I W50R y L60R descriptas en pacientes. En base a ello propongo contestar las siguientes hipótesis:

1. Mutaciones en el extremo el $\mathrm{N}$ - de la ApoA-I inducen pequeñas perturbaciones estructurales que generan una conformación pro amiloidogénica.

2. Las variantes de ApoA-I son más susceptibles que la proteína nativa a la proteólisis.

3. Los ligandos celulares como Glucosaminoglucanos y lípidos negativos presentes en la matriz extracelular interaccionan con las mutantes de ApoA-I incrementando su tendencia a la agregación.

4. Las variantes naturales de ApoA-I inducen activación de la respuesta inmune.

Con el fin de contestar las hipótesis planteadas estudiamos diversos aspectos biofísicos y bioquímicos de las variantes mencionadas en comparación a la proteína Wt. Detectamos diferencias y similitudes inducidas por las mutaciones y planteamos nuevos interrogantes que nos permitirán un conocimiento más exhaustivo del tema en estudio. 


\subsection{PERTURBACIONES ESTRUCTURALES DE LAS VARIANTES NATURALES DE APOA-I.}

Los estudios biofísicos llevados a cabo en este trabajo permiten deducir cambios estructurales sutiles pero significativos de ambas variantes respecto al Wt. Del análisis de la fluorescencia intrínseca (Figuras 5.2 a 5.4 y Tablas 5.1 y 5.2) se desprende que $W 50 R$ presenta una estructura ligeramente más inestable; sus tres $W$ remanentes (en posición 8,72 y 108) se encuentran en promedio más expuestos a la superficie, y se detectan ligeras alteraciones de la estructura terciaria evidenciadas por leves discrepancias de la distribución de los residuos aromáticos en el CD cercano; esta información indica la existencia de pequeñas perturbaciones estructurales en el extremo N. Similar a lo detectado para otras mutantes naturales de ApoA-I analizadas previamente en nuestro laboratorio G26R y $\Delta$ K07-0 (Ramella NA 2012) y R173P (Rosu SA 2015) esta variante exhibe un mayor rendimiento cuántico de la sonda Bis-ANS indicando que la proteína experimenta cierto reordenamiento estructural (Das M 2015). En cambio, conserva el mismo contenido de a hélice. Estas observaciones indican que, a pesar de detectar ligeros cambios estructurales, la conformación de la proteína se ve sólo levemente perturbada por la incorporación del residuo Arginina en posición 50. Más aún, de la observación microscópica de W50R incubada por 7 días a concentraciones superiores a los estudios biofísicos mencionados, no fue posible determinar una agregación sensiblemente más cuantitativa ni morfologías distintas a las encontradas para el Wt (Figura 5.14 A y B). En base a la estructura cristalina de la ApoA-I truncada en el extremo $C$ se propone que W50 se localiza en un segmento libre y extendido comprendido entre los residuos L44-S55 (Das M 2014), lo cual supone que una mutación puntual en este sitio, como es el caso de la variante mencionada, pueda no ser drástica al plegamiento y a la estabilización de un agregado amiloide.

De modo similar a la variante W50R, L60R resulta más inestable que $\mathrm{Wt}$, presenta en promedio los $4 \mathrm{~W}$ más expuestos y la estructura terciaria evidencia diferencias en la disposición de los aminoácidos aromáticos. La modificación estructural inducida por esta mutación es además avalada por el corrimiento del espectro de fluorescencia de los $\mathrm{W}$ en condiciones nativas $(4 \mathrm{~nm}$ hacia mayores longitudes de onda, Tabla 5.1), la pérdida de estructura secundaria 
(aproximadamente $7 \%$ de a hélice) (Figura 5.9) y la desorganización de los bolsillos hidrofóbicos (Figura 5.5).

Así, nuestros datos apoyan y profundizan que la pérdida de leucina en el clúster hidrofóbico inferior induce un cambio drástico en la estructura de la proteína al desestabilizar el dominio de cremallera de leucina formado por L14, L60, L64, L75, L170, L174, L178 y L181 en el haz de hélice (Gursky O 2012).

A fin de conocer si las diversas perturbaciones estructurales detectadas gatillan el agregado anómalo en la variante L60R, se analizó la tendencia de agregación. Las imágenes de MET de L60R (Figura $5.14 \mathrm{C}$ ) sugieren un rendimiento mayor de agregados que el Wt. Por un lado el mayor rendimiento de agregados es evidente dado que a fin de observar la morfología mediante AFM fue necesario diluir 1/10 la muestra para permitir la observación. Esta visualización permitió detectar además, conformaciones definitivamente ausentes en el $\mathrm{Wt}$, como una estructura densa tipo gel y fibras amiloides definidas con espesor de 5-15 nm de espesor (Figura 5.15 D). Es esperable que la conformación final estable tenga lugar en condiciones de mayor tiempo, concentración o por sumatoria de otros eventos no considerados en las condiciones del ensayo (como oxidaciones).

De manera interesante, y a diferencia de lo que ocurre con la mayoría de las proteínas amiloides, la unión de ThT en esta variante fue menor que en la proteína Wt. Dado que ThT censa estructura hoja $\beta$ (Levine H 1999) puede postularse que la agregación de L60R no está mediada por el cambio hacia esta conformación. Si bien la turbidez de la muestra bajo estas condiciones de incubación impide un cálculo estructural preciso, nuestros estudios de CD apoyan esa hipótesis.

La bibliografía existente al momento no permite determinar si este comportamiento es universal para las variantes de ApoA-I, aunque fue descrito que la variante $\mathrm{L} 178 \mathrm{H}$ genera fibras visualizadas por MET de características similares a L60R sin conversión a hoja $\beta$ (Petrlova J 2012) en tiempo similares de incubación. Otro ejemplo reportado lo constituyen los péptidos sintéticos de Vectofusin-1 que se auto agregan mediados por la generación de estructura a hélice (Veermer LS 2017). 
Con la hipótesis que el microambiente celular afecta la conformación proteica, simulamos situaciones que puedan alejarse levemente de la condición fisiológica. Dado que el descenso de pH puede asociarse a isquemia ó inflamación (Coakley RJ 2002), analizamos la influencia de un pH ligeramente ácido, observando que la estabilidad y conformación (Figura 5.2 B) se ven sólo ligeramente afectadas en estas condiciones para ambas variantes en estudio. Otro parámetro que consideramos importante analizar es la influencia de concentraciones elevadas de urea. El riñón es el órgano encargado de ultra filtrar la sangre, eliminando los desechos mediante el mecanismo de contracorriente que ocurre principalmente en la médula renal. Allí la función es llevada a cabo a través del sistema de túbulos provenientes de las unidades funcionales denominadas nefronas. Este sistema tiene distintas secciones cada una con su función asociada, pero en resumen el ultra filtrado se concentra dentro de los mismos por reabsorción de diversas sustancias como agua, glucosa, minerales, entre otras, mientras que en el intersticio renal se acumula cloruro de sodio y urea, llegando ésta a una concentración final de hasta 0.6 M (Vilbig RL 2012, Berne 2009). Consideramos entonces evaluar la posibilidad que la urea pueda inducir un plegamiento anómalo de las variantes de ApoA-I, especialmente de la L60R, dado que su localización como depósitos amiloides ocurre preferentemente en túbulos (Tougaard BG 2016, Gregorini G 2005). Una concentración de urea cercana a $0.6 \mathrm{M}$ es además interesante ya que, en comparación a las curvas de desnaturalización reportadas de las variantes (Figura 5.2 A y B) podrían existir a esas concentraciones estados de plegamiento intermedio que sean más proclives a la agregación.

En nuestras condiciones (baja concentración de proteína y tiempos cortos de incubación) no detectamos una tendencia de agregación en presencia de dicha sustancia, ya sea en condiciones de $\mathrm{pH}$ fisiológico a ligeramente ácido (Figura 5.16 A y B).

\subsection{PROCESAMIENTO PROTEOLÍTICO DE APOA-I Y SUS VARIANTES.}

El análisis de proteólisis parcial ofrece información importante a considerar. Por un lado como fue mencionado el tratamiento con tripsina y 
quimotripsina ha sido utilizado para estimar la flexibilidad estructural proteica. Del análisis predictivo utilizando el software PeptideMass (Expasy.org), la sustitución de la $L$ removería un sitio de corte con quimotripsina en L60R. Dado que para ambas enzimas se observa un aumento en la eficiencia de corte para esta variante, este hallazgo apoya la presencia de una mayor desorganización estructural que permita un mayor acceso a las proteasas ensayadas.

En un enfoque más fisiológico, existe evidencia de que el catabolismo de ApoA-I puede generar fragmentos resultantes de la proteólisis:

1) Extremos $\mathrm{N}$ de la proteína que presentan un peso molecular de 9-11 kDa y son el componente principal de los depósitos amiloides que se localizan en diversos sitios provocando la patogenicidad de la amiloidosis sistémica (Obici L 2006, Pertlova J 2014, Mizuguchi C 2015, Arciello A 2016)

2) Fragmentos inestables como el péptido 1-159 proveniente del clivaje de la variante L159R (Mc Manus DC 2001, Das M 2015). Estos péptidos son catabolizados rápidamente, sin rendir variantes amiloides. Esto podría explicar bajos niveles de ApoA-I circulante.

Estos resultados abren por tanto una pregunta interesante a indagar: ¿el micro ambiente pro inflamatorio podría inducir la liberación de fragmentos $\mathrm{N}$ terminales de variantes de la ApoA-I, con la consecuente acumulación de los mismos dando lugar a la formación de depósitos amiloides?

A fin de profundizar en la respuesta a esta pregunta, comparamos los estudios previos, con la proteólisis inducida por el enzima MMP-12, resultados que apoyaron el análisis estructural expresado arriba. Las metaloproteinasas de

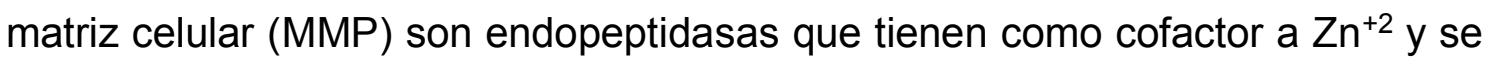
encuentran involucradas en proliferación celular y apoptosis en el parénquima renal llevando a cabo diversas actividades enzimáticas como colagenasa, gelatinasa, remodeladora de matriz, entre otras (Figura 6.1) (Zakiyanov O 2019, Park HJ 2011). Además de ello, las MMPs son liberadas al micro entorno celular ante la presencia de una respuesta inflamatoria, potenciando entre otros efectos el clivaje de citoquinas, quimoatractantes y factores de crecimiento para su posterior activación, lo que perpetúa el foco inflamatorio. La MMP-12 es una elastasa que se sintetiza en los macrófagos renales pero principalmente en el 
glomérulo (Zakiyanov O 2019), y por tanto sería una buena candidata para ser proteasa fisiológica de ApoA-I en dicho sitio en una circunstancia de proceso inflamatorio crónico. La distribución de MMPs definidas a nivel renal es amplia y compleja y está esquematizada en la Figura 6.1

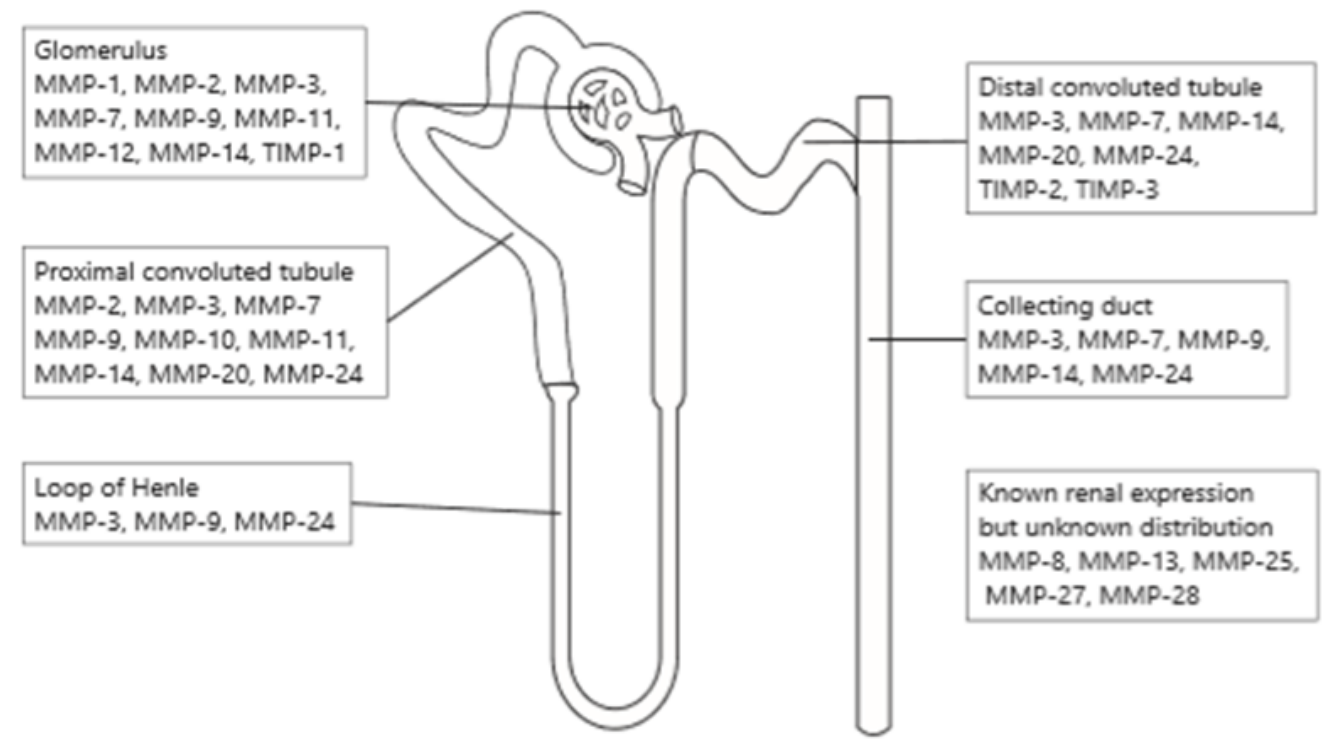

Figura 6.1: esquema de la nefrona indicando las metaloproteinasas predominantes en cada zona. (Zakiyanov O 2019)

En base a ello sería importante discernir cuál o cuáles de dichas MMPs podrían usar como substrato a variantes de ApoA-I. La distinta susceptibilidad observada para W50R y L60R permite inferir que parte al menos de la aparición de depósitos amiloides de ApoA-I a distinto nivel renal podría estar mediada por un procesamiento proteolítico selectivo que favorece la liberación de péptidos más amiloidogénicos que la proteína con la secuencia nativa. En base a los datos presentados en este trabajo, no pareciera ser la proteólisis de W50R por MMP12 un evento que medie en la glomerulopatía característica de esta variante. En estudios previos se ha demostrado que la ApoA-I nativa es proteolizada por diversas MMPs como MMP-3 y MMP-14, siendo esta última más selectiva (Park HJ 2011). Otro ejemplo propuesto de proteasa fisiológica de ApoA-I es la Transtiretina, la cual en circulación se une al $\mathrm{Zn}{ }^{+2}$, haciendo que cambie de conformación y fomentando así su actividad proteolítica (Liz MA 2007, Liz MA 2012). 
Por lo expuesto, creemos que, además del estudio estructural comentado, los ensayos presentados en este trabajo demuestran la factibilidad de un probable procesamiento de ApoA-I y sus variantes in vivo, ya sea en condiciones fisiológicas o en situaciones de inflamación crónica. Este sin duda es un campo complejo que merece continuar profundizándose en la búsqueda de las razones que determinen la órgano especificidad de la amiloidosis debida a ApoA-I.

\subsection{EVALUACION DE LA RELACION ESTRUCTURA-FUNCION}

Dada la bien conocida función de la ApoA-I en la solubilización de lípidos, podría proponerse que una conformación alterada resulte en la disminución de la habilidad de interacción con lípidos. Si esto fuese así, podría redundar en una alteración en la viabilidad de células endoteliales o macrófagos, y en un mayor rendimiento de proteína libre, la que es más susceptible a ser modificada y proclive a la agregación. Esta hipótesis es elevada dado que fue demostrado que la ApoA-I con la secuencia nativa detectada en las lesiones ateromatosas (y asociada a agregados amiloides difusos), se encuentra principalmente libre de lípidos, y modificada mediante oxidación y entrecruzado (Zhu HL 2007). En este marco nos propusimos analizar el efecto de las mutaciones en estudio sobre la funcionalidad de la proteína.

a) Equilibrio monómero - dímero.

Es ampliamente reportado que la ApoA-I con la secuencia nativa en solución presenta un equilibrio monómero - dímero dependiente de la concentración, y que el dímero sería la conformación fisiológica en la interacción con membranas (Zhu HL 2007, Arciello A 2016). Mediante distintos estudios (entrecruzado o cross-linking, dispersión de luz, difracción de rayos $X$ ) de la estructura proteica C- terminal truncada, se propone un modelo de interacción de los dos monómeros de manera antiparalela (Mei X 2011, Melchior JT 2016). Este dímero se encontraría estabilizado por interacciones moleculares presentes en los clusters hidrofóbicos en el sistema de haz de hélices formado por los monómeros constituyentes (Figura 1.4) (Mei X 2011, Melchior JT 2016). Podría proponerse que las mutaciones en estudio generen una desorganización estructural del cluster hidrofóbico inferior induciendo así la desestabilización del dímero 
(Melchior JT 2016). Si esto ocurriera, aumentaría el rendimiento de ApoA-I libre susceptible a la auto agregación (Arciello A 2016). Nuestros experimentos de cromatografía líquida (SEC) nos permitieron confirmar que, en nuestras condiciones de concentración $(0.5 \mathrm{mg} / \mathrm{ml})$ Wt se encuentra predominantemente como dímero y que ambas variantes conservan o incluso estabilizan este estado de oligomerización. Podemos sugerir entonces que el mecanismo patogénico de estas variantes naturales $\mathrm{N}$-terminales de ApoA-I no estaría mediado por el desplazamiento del equilibrio hacia la liberación del monómero. En base a estos datos puede proponerse en cambio que el reemplazo de un aminoácido no polar como $L$ (o W) por uno positivo $(\mathrm{R})$ fortalecería interacciones entre el extremo $\mathrm{N}$ de un monómero y el $\mathrm{C}$ del monómero antiparalelo en el dímero. Si bien estudios más detallados son requeridos para confirmar la naturaleza de esta interacción, tanto interacciones $\pi$-cation como nuevos puentes salinos podrían ser esperables de ocurrir en las variantes.

b) Solubilización de lípidos

La ApoA-I libre tiene la capacidad de interactuar con el transportador ABCA1 permitiendo así la captación de fosfolípidos y colesterol, para su vehiculización desde tejidos periféricos y hacia el hígado para el TRC (Obici L 2006, Curtiss LK 2006). Ya sea mediando interacción con receptores o de modo pasivo, esta proteína, en su forma libre de lípidos como reconstituida en partículas lipoproteicas ha demostrado ser buen aceptor de fosfolípidos en modelos in vitro y hasta ha sido utilizada en modelo pre clínicos con pacientes (Martin DO 2012, Del Giudice R 2017, Salnikov ES 2018). Ha sido reportado que la ApoA-I solubiliza fosfolípidos en presencia de detergentes como el colato, o a partir de liposomas a la temperatura de transición del lípido, donde la existencia de defectos en la bicapa es máxima (Pownall 1978) Un ensayo ampliamente utilizado para esos estudios es la evaluación del aclaramiento de la absorbancia (como medición de turbidez) cuando la ApoA-I se enfrenta a liposomas multilamelares de DMPC a su temperatura de transición $\left(24^{\circ} \mathrm{C}\right)$; en estas condiciones la absorbancia disminuye rápidamente a medida que, como producto de la interacción la proteína se reordena formando partículas discoidales proteína:DMPC de $\sim 12-18$ nm (Das M 2014, Del Guidice R 2017). Como se observa en la Figura 5.21, la capacidad de la variante L60R de 
solubilizar fosfolípidos no se ve sensiblemente afectada por la mutación (previamente había sido demostrado que tampoco ocurrió un entorpecimiento en esta función del W50R (Das M 2014)). Como la Figura 6.2 esquematiza, el reemplazo de la $R$ por la $L$ en posición 60 ocurriría en el límite entre la cara polar y la no polar de la hélice anfipática, por lo que sería probable que esta sustitución no distorsione drásticamente la superficie que interactúa con lípidos.

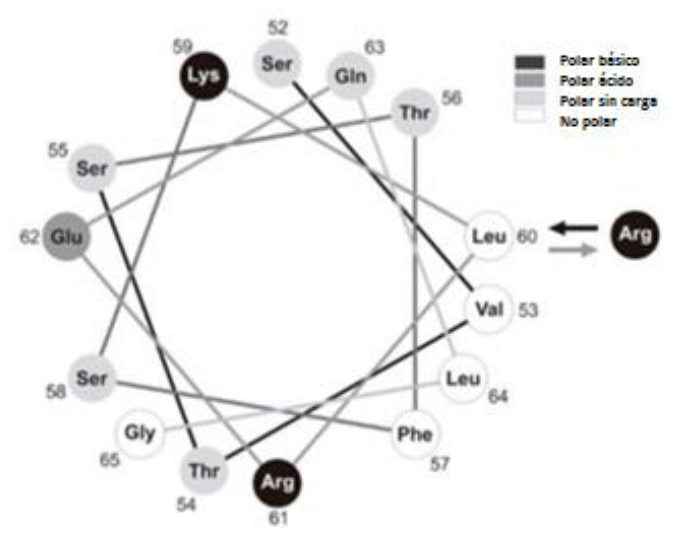

Figura 6.2: Representación del modelo de alfa hélice. Secuencia del péptido 52-65 representada como una hélice vista desde arriba de un eje longitudinal, con una disposición de aminoácidos considerando una hélice a ideal (rotación de $100^{\circ}$ por aminoácido). Escala de grises en la figura corresponde a la naturaleza de diferentes aminoácidos. Hacia el lado derecho de la hélice se indica el reemplazo de Leu por Arg en la posición 60 en la fase no polar.

\subsection{UNIÓN A LIGANDOS CELULARES}

La conocida flexibilidad estructural de la ApoA-I y los resultados mencionados en este trabajo dan lugar a elevar la hipótesis que interacciones con moléculas del micro ambiente celular puedan desplazar el equilibrio entre una estructura funcional de la proteína y otra (ú otras) mal plegadas. Para chequear esta posibilidad analizamos la unión de la ApoA-I y sus variantes a ligandos modelo de los esperables en un ambiente fisiológico: a) al SDS, molécula anfipática que ha sido utilizada como modelo de lípido negativo, y b) a modelo de glicosamino glicanos componentes de la matriz extracelular (heparina).

a) Interacción con SDS 
Ha sido reportado por nuestro grupo que la ApoA-I puede tornarse pro-amiloide en un microambiente pro-inflamatorio como el asociado a aterosclerosis (Ramella NA 2011). La fosfatidilserina es un fosfolípido negativo que se expone en las membranas de células apoptóticas y podría proponerse que una densidad negativa en células de la placa podría promover su agregación (Zhao H 2004). El SDS, en concentraciones submicelares (Rosú SA 2015, Ahmad MF 2006, Khan VM 2016), permite indagar acerca del efecto de la interacción ligando anfipático-proteína. Fue usado asimismo como inductor de formación de fibras amiloides a partir de otras proteínas como la a sinucleína (Ahmad 2006, Giehm L 2010, Giehm L 2011) y lisozima (Khan MS 2018). Del análisis de la Figura 5.18 es evidente un aumento en la interacción de SDS:apoA-I hasta un máximo 0.7 $\mathrm{mM}$ de SDS. Más aún, el agregado del ligando resulta (quizá inverso a lo esperado debido a su probable naturaleza como detergente) en un corrimiento de los residuos W hacía un ambiente no polar (Figura 5.20). Este dato resulta interesante en distintos aspectos. En primer término muestra la vulnerabilidad de la estructura proteica ante agentes presentes en el microambiente, en el que la naturaleza anfipática parece ser clave. Previamente demostramos que altas concentraciones de $\mathrm{CINa}$ inhiben este efecto, indicando al menos interacciones electrostáticas mediando la formación de complejos (Rosú SA 2015). Como fue descripto arriba, la secuencia de la ApoA-I tiene alto contenido de hélices anfipáticas de la clase $\mathrm{A}$, donde la cara hidrofóbica está rodeada de una cara polar voluminosa en la cual predominan los residuos positivos cercanos a la interface de la hélice (Figura 1.2). En nuestras condiciones experimentales, la máxima intensidad de fluorescencia de ThT resulta en una relación molar de 100:1 SDS:Apo (0.7 mM de SDS en contacto con $7 \mu \mathrm{M}$ de proteína). Podría proponerse, como se esquematiza en la Figura 6.3, que en esas condiciones es máxima la unión de la cabeza polar del SDS a la cara positiva de las hélices, y que esa interacción pueda luego generar un reordenamiento de la proteína a medida que las colas acílicas del SDS interactúan entre sí mediante interacciones hidrofóficas. Esta observación es apoyada por el reordenamiento de los W observado por el corrimiento de fluorescencia (Figura 5.19). Es interesante resaltar nuevamente las diferencias estructurales entre ambas variantes. Mientras que L60R es más influenciada en esta interacción, W50R no parece tener una modificación más drástica que el Wt. Por encima de la CMC el 
SDS forma micelas y por lo tanto su eficiencia de interacción se ve debilitada, ya que predomina las interacciones ligando-ligando (Figura 6.3).

Figura 6.3 Mecanismo propuesto de interacción de variantes con SDS. Se propone una primer interacción de la cabeza polar negativa del SDS con la cara polar positiva de las a hélices (cara roja), y un posterior cambio conformacional al interactuar cooperativamente las colas acílicas.

b) Unión a Heparina

En tejidos y órganos, los GAGs forman parte de los proteoglucanos,
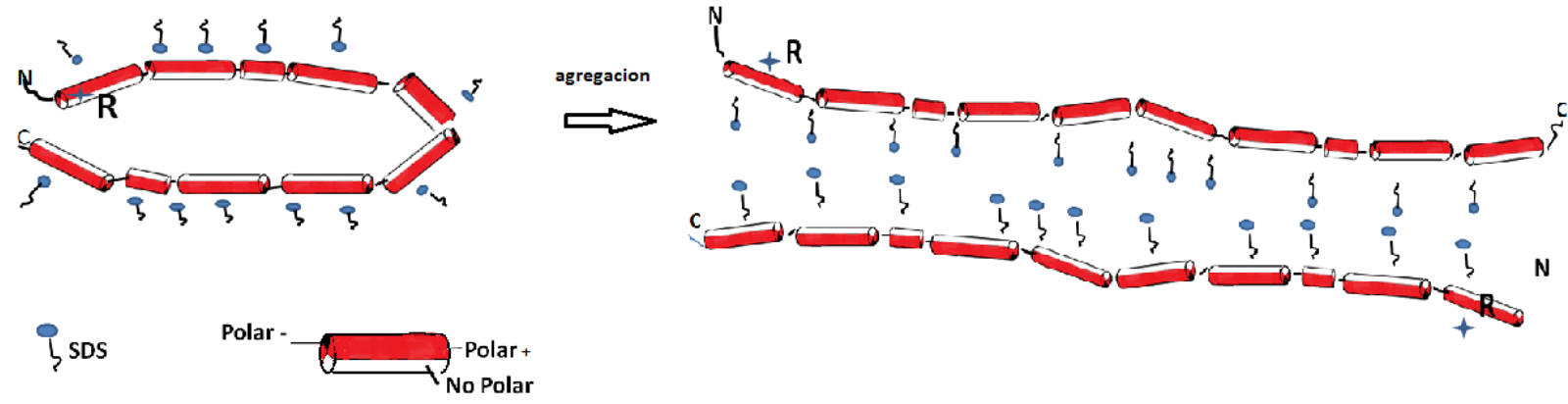

constituyendo gran parte de las matrices extracelulares y participando en varios procesos fisiológicos (Kinsella MG 2004, Bernfield M 1992). Pero, además, amplia evidencia destaca la participación de estas moléculas en eventos patológicos como aterosclerosis y amiloidosis (Gutierrez P 1997; O`Brien KD 1997; Zhang X 2010: Solomon JP 2011; lannuzzi C 2015). El mecanismo por el cual se favorece la retención o mal plegamiento de proteínas, conduciendo a su depósito en los tejidos es todavía incierto, pero varias hipótesis atribuyen un rol fundamental a las interacciones que pueden establecerse entre dichas proteínas y los GAGs. La importancia de dilucidar los mecanismos implicados en dicha interacción radica en el avance en estrategias terapéuticas. Por un lado, fue descubierto que un grupo de GAGs, las heparinas de bajo peso molecular, participan de una manera particular inhibiendo la formación de agregados $\beta$ amiloides (Ariga T 2010). Por otra parte, el rol atribuido a los grupos sulfato, 
permitió el diseño de compuestos anti-amiloides para el tratamiento de las mencionadas patologías (Rumjon A 2012)

La heparina constituye un modelo de GAG que ha sido ensayado extensamente. Si bien esta macromolécula in vivo es solo liberada por los mastocitos, su similitud química con el heparán sulfato (distribuido en varios tejidos) y su fácil acceso comercial permitieron diversos estudios de interacción con proteínas (Frati-Munari AC, 2012). Estudios de nuestro laboratorio demostraron que, si bien la unión de la ApoA-I Wt a heparina es indistinguible a $\mathrm{pH}$ fisiológico, esta interacción se incrementa ante un microambiente acídico, probablemente debido al fortalecimiento de interacciones electrostáticas dado por el aumento de la carga positiva de la proteína en función del pH. Nuestro grupo ha propuesto la generación de un probable sitio de unión a heparina formado por una Arg (en posición 151) y dos His (155 y 162). Dada la periodicidad esperada en una alfa hélice, estos tres residuos estarían próximos en la cara polar, de modo tal que por debajo de $\mathrm{pH} \sim 6.0$ la protonación de las histidinas genera una zona con alta carga positiva que uniría eficientemente a GAGs negativos (Ramella NA 2011, Townsend D 2017). Otros ensayos evidenciaron la interacción de variantes de ApoA-I amiloidogénicas con heparina, incluso a pH fisiológico (Rosu SA 2015). En los resultados ensayados en este trabajo no observamos (al igual que ocurrió previamente con la $\mathrm{Wt}$ ) formación de complejos entre las variantes de ApoA-I estudiadas y heparina a $\mathrm{pH}$ 7.4. En cambio a pH ácido la unión a ThT de la variante W50R en presencia de dicho GAG fue incrementada respecto al Wt y a L60R (Figura 5.14). Podría proponerse, como fuera sugerido por Mikawa y col, que la incorporación de $\mathrm{R}$ cercano a los residuos nativos $\mathrm{K} 45, \mathrm{~K} 59$, y $\mathrm{R} 61$ podría resultar en la formación de un sitio de reconocimiento para la heparina (Mikawa S 2016) y el descenso de $\mathrm{pH}$ local favorecería a la estructura más laxa que permita la exposición del sitio.

Es interesante recordar que si bien ambos mutantes causan amiloidosis renal, la distribución tisular que presentan es diferente, siendo el W50R de localización glomerular (Tougaard BG 2016), mientras que el L60R es más de predominio túbulo intersticial (Gregorini G 2015), por lo que el hecho de que presenten una unión diferencial a heparina, nos sugiere que quizás su 
interacción con GAGs en el entorno pueda ser distinta también. En el glomérulo normal predominan los proteoglucanos de heparán sulfato, como perlecano y agrina (Borza DB 2017), y frente a patologías renales como nefropatía y glomérulo esclerosis (dos enfermedades relacionadas con la formación de depósitos amiloides), se ha visualizado un aumento de la expresión de perlecano (Chan C 2019). La región túbulo intersticial, en cambio, está compuesta de GAGs como ácido hialurónico (HA) (Stridh S 2011), decorina y biglicano, dos proteoglucanos constituidos por condroitín sulfato (CS) y dermatan sulfato (DS) (Stokes MB 2001). Por tal motivo, sería interesante sugerir que al menos parte de la retención selectiva de esta variante pueda deberse a la afinidad por distintos componentes de la matriz extracelular. Esta posibilidad será indagada a futuro.

\subsection{ACTIVACIÓN DE RESPUESTA INFLAMATORIA DE APOA-I Y SUS VARIANTES}

Ha sido previamente postulado que la ApoA-I posee propiedades anti inflamatorias, mediante la regulación de vías metabólicas como JAK2- STAT3 en macrófagos activados, en las que favorece la supresión de síntesis de citoquinas (Zhao H 2012). Sin embargo, podría sugerirse la hipótesis que los cambios conformacionales demostrados en las variantes puedan resultar en la activación de una respuesta de inmunidad innata. Recientemente, en nuestro grupo de trabajo, se ha indagado en las vías inflamatorias de variantes de ApoA-I. Se demostró que la variante pro amiloide, G26R actúa como DAMP, en un modelo celular de macrófagos RAW 264.7, potenciando la señalización de la vía NFKß; este factor de transcripción es un heterodímero (p50-p65) que, en condiciones basales se localiza en el citosol y se encuentra unido a una proteína llamada IK$\beta$, impidiendo su translocación nuclear; cuando la vía se activa, IK- $\beta$ se fosforila y luego se degrada, por lo que NFK $\beta$ se dirige al núcleo desencadenando la transcripción de óxido nítrico sintasa inducible (i NOs), ciclo oxigenasa (COX) y citoquinas pro inflamatorias (Ramella NA 2018). Este mecanismo está esquematizado en la Figura 6.4 


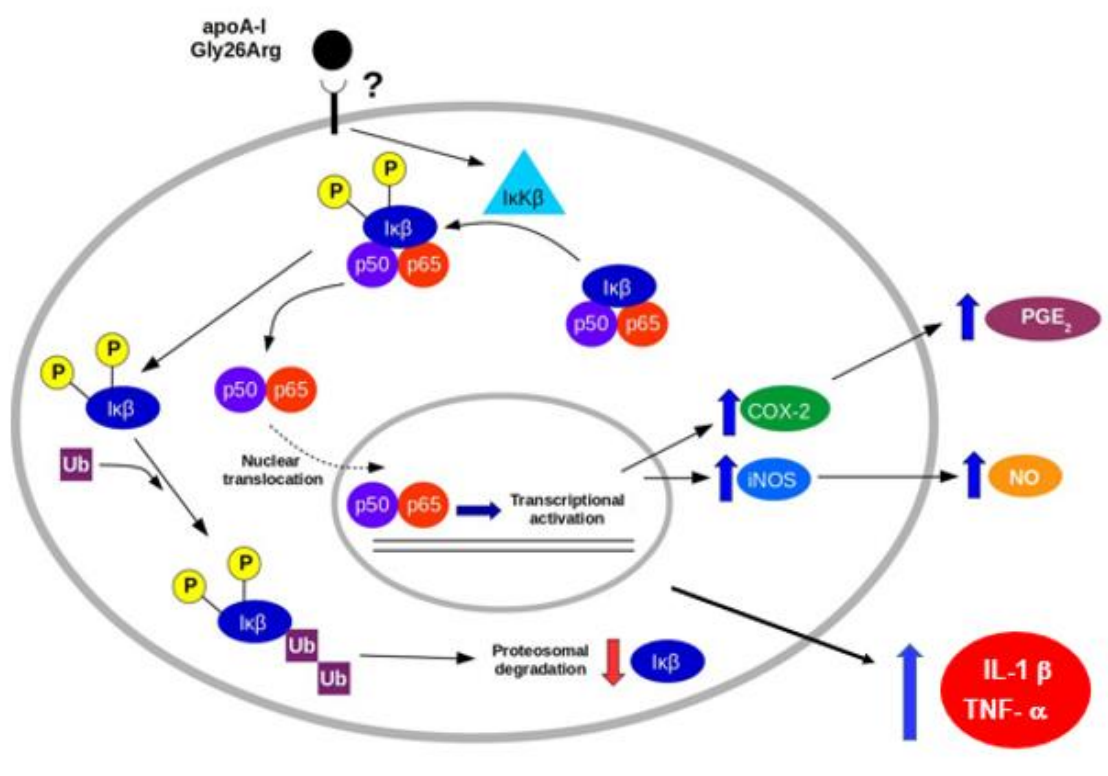

Figura 6.4: Esquema de activación de la vía inflamatoria $\mathbf{N F k} \boldsymbol{\beta}$. El mecanismo fue propuesto para la variante ApoA-I G26R (Ramella NA 2018).

En este trabajo se analizó la probable liberación de citoquinas pro inflamatorias TNFa e IL-1 $\beta$ utilizando un modelo celular de macrófagos humanos (células THP-1) que fueron expuestos a las variantes de ApoA-I solubles. De manera interesante, mientras que W50R en las condiciones analizadas mostró ausencia de activación de macrófagos al igual que Wt, L60R indujo la liberación de citoquinas pro inflamatorias, haciendo que el sistema inmune la reconozca como DAMP al igual que G26R. Este hallazgo nuevamente abre la inquietud de indagar sobre la conformación proteica que pueda ser más activa en el inicio de estas vías. Estructuras fibrilares de otras proteínas amiloides fueron capaces de activar macrófagos en la liberación de citoquinas o la liberación de trampas de elastasas a partir de neutrófilos y recientemente nuestro grupo demostró el mismo efecto a partir de estructuras fibrilares de proteína oxidada (Azevedo EPC 2012, Brinkmann V 2007, Gisonno RA 2020).

Es interesante también la observación que la forma oxidada de Wt en las metioninas 86 y 148 solubles induce liberación IL $1-\beta$, IL-6 pero no un aumento de la síntesis de pro IL-1 $\beta$ de un modelo de células de medula ósea de ratón y 
esta tendencia disminuye cuando la proteína se organiza como fibras (Witkowski A 2019). Así, este sería un gran punto de partida para indagar sobre cuál es la forma en la cual las variantes de ApoA-I producen una respuesta inflamatoria: si las fibras o la forma soluble que puede ser modificada por oxidaciones o bien por el descenso del pH del micro entorno celular característico de los procesos inflamatorios (Oorni K 2014).

\section{CONCLUSIONES GENERALES DE LOS MECANISMOS} AMILOIDOGENICOS DE LAS VARIANTES N-TERMINALES DE APOA-I

Los estudios realizados en este trabajo fuertemente sugieren que el establecimiento crónico de la amiloidosis debida a ApoA-I es la consecuencia de una pérdida de la conformación nativa de las variantes naturales, lo que puede alterar el delicado equilibrio entre una conformación soluble funcional y otra patológica. Pero además de manera interesante nuestros datos avalan que los complejos mecanismos que participan no son universales a todas las variantes de apoA-I, y que puedan justificar además el por qué el depósito de las mismas es órgano específico.

Resumo los hallazgos principales que surgen como indicios para cada variante:

\subsection{L60R}

El reemplazo de Leu por Arg en el residuo 60 introduce una desorganización estructural del extremo N. Esta estructura es más inestable y más propensa a agregarse que la proteína Wt, lo que podría explicar en parte su presencia en lesiones amiloides.

La mayor susceptibilidad a la proteólisis observada para esta variante sugiere además que podría ser mejor blanco de enzimas proteolíticas (aún no identificadas en circulación), que favorezca su catabolismo y más interesante aún la presencia del péptido $\mathrm{N}$ terminal que suele ser identificado en lesiones de pacientes. Finalmente, es de interés la observación que la estructura de la proteína soluble podría despertar localmente una respuesta inflamatoria innata y 
perpetuar por tanto el cuadro crónico inflamatorio que acompaña esta patología. Esta información está resumida en la Figura 7.1

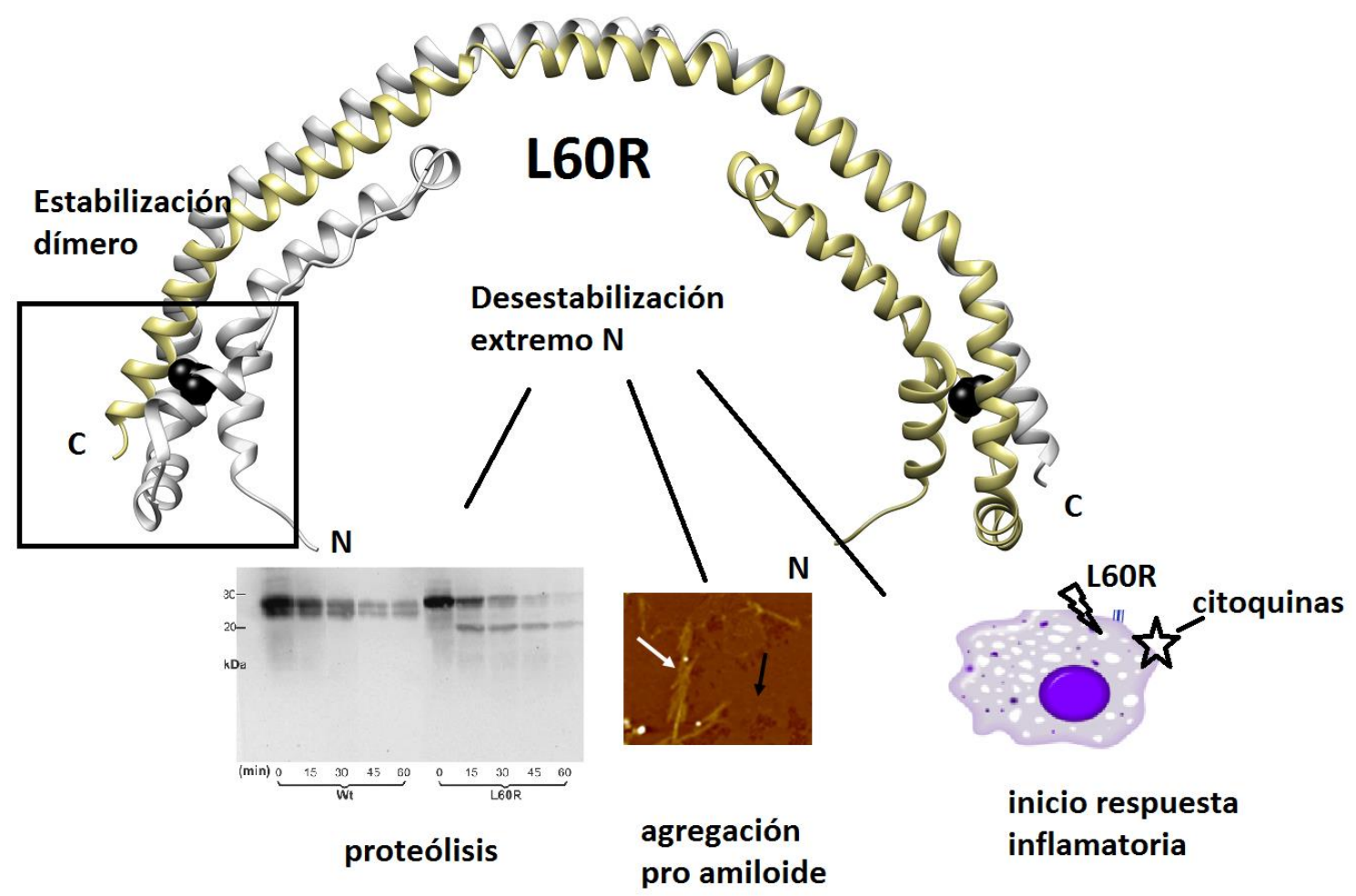

Figura 7.1. Esquema con los posibles mecanismos amiloidogénicos de la variante natural L60R. Esta mutante presenta un aumento en la susceptibilidad a proteasas lo que permite la liberación fragmentos proteolíticos, los cuales estarían presentes en los depósitos amiloides, activación de la respuesta inflamatoria crónica mediante la liberación al micro entorno celular de citoquinas pro inflamatorias y por último, la formación de fibras amiloides de 5-15 nm de espesor.

\subsection{W50R}

Esta variante comparte ciertos comportamientos similares a la anterior como lo es la adquisición de una estructura más inestable y con la región $\mathrm{N}$ terminal más desorganizada que la proteína Wt. En cambio los sutiles cambios observados no parecen resultar en consecuencias drásticas respecto a la tendencia a agregarse, a ser substrato de proteasas o a ser reconocida por el sistema de inmunidad innata. Sin embargo, es interesante la observación de una mayor interacción con glicosamino glicanos modelo usados en este trabajo. Dada la riqueza del glomérulo renal en estas moléculas de alta carga negativa, podría proponerse que la retención de esta variante en la corteza renal pueda 
deberse a mayor retención y/o agregación del W50R en asociación con la matriz extracelular. Estos resultados están resumidos en la Figura 7.2.

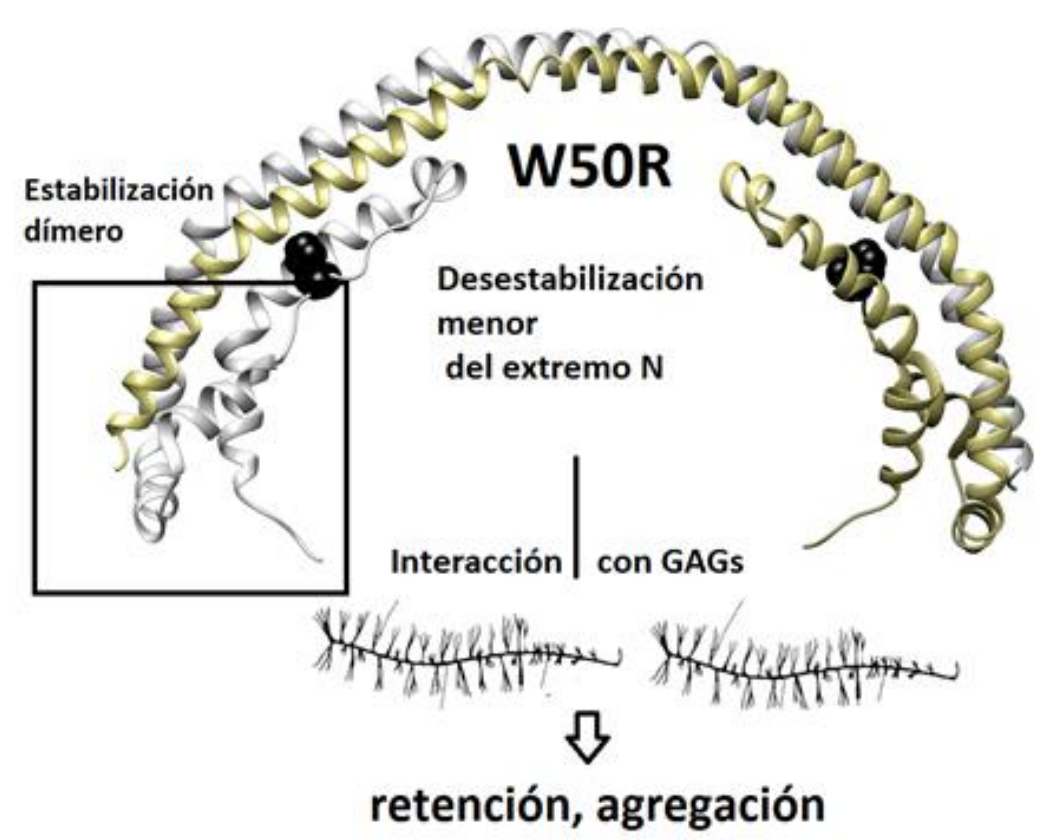

Figura 7.2. Mecanismo amiloidogénico de la variante natural W50R. La mutante presenta la capacidad de unirse a GAGs en el glomérulo haciendo que sea más retenida en el micro entorno celular y promoviendo así su agregación.

\section{PERSPECTIVAS}

Varios de los resultados discutidos en este trabajo ofrecen interesantes campos a seguir profundizando.

- Determinar si la forma soluble de las variantes naturales de ApoA-I, tal como L60R, o bien las fibras preformadas son responsables de generar citotoxicidad (de ser así profundizar en los eventos celulares involucrados).

- Determinar los factores que puedan dar lugar a la conformación fibrilar final

- Analizar si un péptido liberado del evento de proteólisis puede ser o no responsable de respuestas citotóxicas (de ser así búsqueda de la proteasa fisiológica de la proteólisis específica) 
- Estudiar la relación de las variantes naturales de ApoA-I con la matriz extracelular tanto de glomérulo como médula renal, a fin de determinar la posible causa de la retención órgano- específica.

- Indagar si la interacción de las variantes con ligandos anfipáticos promueve la formación de fibras tipo amiloide y si estas son productos citotóxicos. 


\section{BIBLIOGRAFÍA}

Ahmad MF, Ramakrishna T, Raman B, et al. Fibrillogenic and non-fibrillogenic ensembles of SDS-bound human alpha-synuclein. J Mol Biol. 2006;364 (5):10611072.

Arciello A, Piccoli R and Monti DM. Apolipoprotein A-I: the dual face of a protein. FEBS Letters. 2016; 590 (23): 4171-4179.

Ariga T, Miyatake, T and Yu RK. Role of proteoglycans and glycosaminoglycans in the pathogenesis of Alzheimer's disease and related disorders: Amyloidogenesis and therapeutic strategies-A review. J. Neurosci. Res. 2010; 88 (11): 2303-2315

Azevedo EPC, Guimarães-Costa AB, Torezani GS, et al. Amyloid fibrils trigger the release of neutrophil extracellular traps (NETs), causing fibril fragmentation by NET associated elastase. J Biol Chem. 2012; 287 (44): 37206-37218.

Berne y Levy. Fisiología. El sistema renal. 2009; Elsevier $6^{\circ}$ ed.

Bernfield M, Kokenyesi R, Kato M,et al. Biology of the Syndecans: A Family of Transmembrane Heparan Sulfate Proteoglycans. Annu Rev Cell Biol. 1992;8 (1):365-393.

Bibow S, Polyhach Y, Eichmann C, et al. Solution structure of discoidal highdensity lipoprotein particles with a shortened apolipoprotein A-I. Nat Struct Mol Biol. 2017; 24(2): 187-193.

Booth DR, Tan SY, Booth SE, et al. A new apolipoprotein al variant, trp50arg, causes hereditary amyloidosis. QJM. 1995;88 (10): 695-702.

Borza DB. Glomerular basement membrane heparan sulfate in health and disease: a regulator of local complement activation. Matrix Biol. 2017;57-58:299310.

Bourgault S, Solomon JP, Reixach $\mathbf{N}$ et al. Sulfated glycosaminoglycans accelerate transthyretin amyloidogenesis by quaternary structural conversion. Biochemistry. 2011; 50 (6): 1001-1015.

Bradford MM. A rapid and sensitive method for the quantitation of microgram quantities of protein utilizing the principle of protein-dye binding. Anal Biochem. 1976; 72:248-254. 
Brinkmann V, Zychlinsky A. Beneficial suicide: Why neutrophils die to make NETs, Nat. Rev. Microbiol. 2007; 5 (8):577-582.

Chan C, Eng DG, Miner JH, et al. Differential Expression of Parietal Epithelial Cell and Podocyte Extracellular Matrix Proteins in Focal Segmental Glomerulosclerosis and Diabetic Nephropathy. Am J Physiol Renal Physiol. 2019; 317(6): F1680-F1694.

Coakley RJ, Taggart C, McElvaney NG, et al. Cytosolic $\mathrm{pH}$ and the inflammatory microenvironment modulate cell death in human neutrophils after phagocytosis. Blood 2002; 100 (9): 3383-3391.

Córsico B, Falomir Lockhart LJ, Franchini GR, et al. Análisis estructural y funcional de macromoléculas. 2016; Portal de Libros de la Universidad Nacional de La Plata.

Curtiss LK, Valenta DT, Hime NJ et al. What is so special about apolipoprotein Al in reverse cholesterol transport? Arterioscler Thromb Vasc Biol. 2006; 26 (1):12-19.

Das $\mathbf{M}$ and Gursky $\mathbf{O}$. Amyloid-forming properties of human apolipoproteins: sequence analyses and structural insights. Adv Exp Med Biol. 2015;855: 175211.

Das $\mathbf{M}$, Mei $\mathbf{X}$, Jayaraman $\mathbf{S}$, et al. Amyloidogenic mutations in human apolipoprotein A-I are not necessarily destabilizing - a common mechanism of apolipoprotein A-I misfolding in familial amyloidosis and atherosclerosis. FEBS J. 2014; 281 (11):2525-2542.

Davidson WS, Arnvig-McGuire K, Kennedy A, et al. Structural organization of the N-terminal domain of apolipoprotein A-I: studies of tryptophan mutants. Biochemistry 1999; 38 (43): 14387-14395

Davidson, WS, Hazlett, T, Mantulin, WW et al. The role of apolipoprotein AI domains in lipid binding.Proc. Natl. Acad. Sci. USA. 1996; 93: 13605-13610

Del Giudice R, Arciello A, Itri F, et al. Protein conformational perturbations in hereditary amyloidosis: differential impact of single point mutations in ApoAI amyloidogenic variants. Biochim Biophys Acta. 2016; 1860 (2):434-444. 
Del Giudice R, Nilsson O, Domingo-Espín J et al. Synchrotron radiation circular dichroism spectroscopy reveals structural divergences in HDL bound apoA-I variants. Sci Rep. 2017; 7(1): 13540-13549.

Dember LM. Amyloidosis-associated kidney disease. J Am Soc Nephrol. 2006;17 (12):3458-3471.

Eckhardt D, Li-Blatterb X, Schönfeld H-J et al. Cooperative unfolding of apolipoprotein A-1 induced by chemical denaturation. Biophys Chem. 2018; 240:42-49.

Ellis RA. Principles and techniques of electron microscopy: Biological applications, Cell.1979; 17 (9): 235-236.

Eriksson M, Schönland S, Yumlu S, et al. Hereditary apolipoprotein Alassociated amyloidosis in surgical pathology specimens: Identification of three novel mutations in the APOA1 gene. J Mol Diagn. 2009;11 (3): 257-262.

Frati-munari AC. Glicosaminoglicanos en las enfermedades vasculares. 2012; 40 (3).

Giehm L, Lorenzen $\mathbf{N}$ and Otzen DE. Assays for a-synuclein aggregation. Methods. 2011;53 (3): 295-305.

Giehm L, Oliviera CLP, Christiansen G, et al. SDS- induced fibrillation of a synuclein: An alternative fibrillation pathway. J Mol Biol. 2010; 401(1):115-133.

Gisonno RA, Prieto ED, Gorgojo JP et al. Fibrillar conformation of an apolipoprotein A-I variant involved in amyloidosis and atherosclerosis. Biochim Biophys Acta (BBA) Gen Subjects 2020; 1864 (4):129515.

Greenfield NJ. Circular Dichroism Analysis for Protein-Protein Interactions. Protein-Protein Interactions, 2015; Springer ed.

Gregorini G, Izzi C, Obici L, et al. Renal apolipoprotein A-I amyloidosis: a rare and usually ignored cause of hereditary tubulointerstitial nephritis. J Am Soc Nephrol. 2005;16 (12):3680-3686.

Gregorini G, Izzi C, Ravani P, et al. Tubulointerstitial nephritis is a dominant feature of hereditary apolipoprotein A-I amyloidosis. Kidney Int. 2015; 87 (6): 1223-1229.

Gursky $\mathbf{O}$ and Atkinson D. Thermal unfolding of human high-density apolipoprotein A-i : Implications for a lipid-free molten globular state. 1996; 93 (7): 2991-2995. 
Gursky $\mathbf{O}$, Mei $\mathbf{X}$ and Atkinson D. The crystal structure of the C-terminal truncated apolipoprotein A-I sheds new light on amyloid formation by the $\mathrm{N}$ terminal fragment. Biochemistry. 2012; 51(1):10-18

Gutierrez P, O'Brien KD, Ferguson M, et al. Differences in the Distribution of Versican, Decorin, and Biglycan in Atherosclerotic Human Coronary Arteries. Cardiovasc Pathol. 1997; 6(5):271-278.

Hamidi AK, Liepnieks JJ, Nakamura M, et al. A novel apolipoprotein A-1 variant, Arg173Pro, associated with cardiac and cutaneous amyloidosis. Biochem Biophys Res Commun. 1999; 257 (2):584-588.

Hutton HL, Ooi JD, Holdsworth SR et al. The NLRP3 inflammasome in kidney disease and autoimmunity. Nephrology 2016; 21 (9):736-744

ladanza MG, Jackson MP, Hewitt EW, et al. A new era for understanding amyloid structures and disease. Nat Rev Mol Cell Biol. 2018;19(12):755-773.

lannuzzi C, Irace G, Sirangelo I. The effect of glycosaminoglycans (GAGs) on amyloid aggregation and toxicity. Molecules. 2015; 20(2):2510-2528.

Khan MS, Bhat SA, Rehman T, et al. Rutin attenuates negatively charged surfactant (SDS)-induced lysozyme aggregation/amyloid formation and its cytotoxicity. Biol Macromol. 2018;120 (Pt A):45-58.

Khan VM, Kanika Arora PS, Kishor N, et al. The Achilles' heel of 'ultrastable' hyperthermophile proteins: Submillimolar concentrations of SDS stimulate rapid conformational change, aggregation and amyloid formation in proteins carrying overall positive charge. Biochemistry 2016; 55 (28): 3920-3936.

Kidd J and Carl DE. Renal amyloidosis. Current problems in cancer. 2016; 40 (5-6): 209-219

Kinsella MG, Bressler SL, Wight TN. The regulated synthesis of versican, decorin, and biglycan: extracellular matrix proteoglycans that influence cellular phenotype. Crit Rev Eukaryot Gene Expr. 2004;14 (3):203-234.

Kuwabara K, Nishitsuji K ,Uchimura K. et al. Cellular Interaction and cytotoxicity of the lowa mutation of apolipoproteinA-I (ApoA-Ilowa) amyloid mediated by sulfate moieties of Heparan Sulfate. J Biol Chem. 2015; 290 (40): 24210-24221 
Lakowicz JR. Principles of fluorescence Spectroscopy. 2006; Springer New York ed.

Lensen JF, van der Vlag J, Versteeg EM et al. Differential expression of specific Dermatan Sulfate domains in renal pathology. PloS One 2015;10(9):e0134946.

LeVine H. Quantification of beta-sheet amyloid fibril structures with thioflavin T. Methods Enzymol. 1999; 309:274-284

Liz MA, Gomes CM, Saraiva MJ, et al. ApoA-I cleaved by transthyretin has reduced ability to promote cholesterol efflux and increased amyloidogenicity.J Lipid Res. 2007; 48: 2385-2395.

Liz MA, Leite SC, Juliano L, et al. Transthyretin is a metallopeptidase with an inducible active site. Biochem J. 2012; 443(3):769-78.

Lu C, Zuo K, Lu, Y, et al. Apolipoprotein A-I related amyloidosis 2 case reports and a review of the literature. Medicine (Baltimore). 2017; 96 (39):e8148.

Martin DO, Budamagunta MS, and Ryan RO. Apolipoprotein A-I assumes a "looped Belt" conformation on reconstituted High Density Lipoprotein. J Biol Chem. 2006; 281 (29): 20418 -20426.

McGrath K, Li XH, Twigg SH, et al. Apolipoprotein-Al mimetic peptides D-4F and L-5F decrease hepatic inflammation and increase insulin sensitivity in C57BL/6 mice. PloS One. 2020; 15 (1):e0226931

McManus DC, Scott BR, Franklin V, et al. Proteolytic degradation and impaired secretion of an apolipoprotein A-I mutant associated with dominantly inherited hypoalphalipoproteinemia.J Biol Chem 2001; 276 (24):21292-21302.

Mei X and Atkinson D. Crystal structure of C-Terminal truncated apolipoprotein A-I reveals the assembly of High Density Lipoprotein (HDL) by dimerization. J Biol Chem 2011; 286 (44):38570-38582.

Melchior JT, Walker RG, Morris $\mathbf{J}$ et al. An evaluation of the crystal structure of C-terminal truncated apolipoprotein A-I in solution reveals structural dynamics related to lipid binding. J Biol Chem. 2016; 291(10):5439-5451

Merlini G and Bellotti V. Molecular mechanisms of amyloidosis. N Engl J Med. 2003; 349 (6):583-596. 
Mikawa S, Mizuguchi C, Nishitsuji K, et al. Heparin promotes fibril formation by the N-terminal fragment of amyloidogenic apolipoprotein A-I. FEBS Letters. 2016; 590 (20): 3492-3500.

Mizuguchi C, Ogata F, Mikawa S, et al. Amyloidogenic mutation promotes fibril formation of the N-terminal apolipoprotein A-I on lipid membranes. J Biol Chem 2015; 290 (34): 20947-20959.

Morgado I, Panahi A, Burwash AG, et al. Molecular insights into human hereditary apolipoprotein A-I amyloidosis caused by the Glu34Lys mutation. Biochemistry. 2018; 57 (39): 5738-5747

Mucchiano GI, Jonasson L, Häggqvist B et al. Apolipoprotein A-I-derived amyloid in atherosclerosis. Its association with plasma levels of apolipoprotein AI and cholesterol. Am J Clin Pathol 2001; 115, 298-303.

Munishkina LA and Fink AL. Fluorescence as a method to reveal structures and membraneinteractions of amyloidogenic proteins. Biochim et Biophys Acta (BBA) - Biomembranes, 2007; 1768 (8):1862-1885

Namiri-Kalantari R, Gao F, Chattopadhyay A, et al. The dual nature of HDL: Anti-inflammatory and pro-inflammatory. Biofactors. 2015; 41 (3):153-159

Obici L, Franceschini G, Calabresi L, et al. Structure, function and amyloidogenic propensity of apolipoprotein A-I. Amyloid. 2006; 13 (4):191-205.

O’Brien KD, Olin KL, Alpers CE, et al. Comparison of apolipoprotein and proteoglycan deposits in human coronary atherosclerotic plaques: Colocalization of biglycan with apolipoproteins. Circulation. 1998; 98 (6):519-527.

Oda MN. Lipid-free apoA-I structure - Origins of model diversity. Biochim et Biophys Acta (BBA) 2017; 1862 (2): 221-233.

Öorni k, Rajamäki K, Nguyen SD, et al. Acidification of the intimal fluid: the perfect storm for atherogenesis. J Lipid Res, 2015; 56 (2):203-214.

Pace CN Determination and analysis of urea and guanidine hydrochloride denaturation curves. Methods Enzymol.1986;131: 266-280.

Park EK, Jung HS, Yang HI, et al. Optimized THP-1 diferentiation is required for the detection of responses to weak stimuli. Inflamm Res. 2007; 56(1):45-50.

Park HJ, Park S-M, Park K-H, et al. Analysis of Apolipoprotein A-I as a substrate for matrix metalloproteinase-14. Biochem Biophys Res Commun. 2011; 27;409(1):58-63. 
Petrlova J, Dalla-Riva J, Lindahl M, et al. Secondary structure changes in ApoA-I Milano (R173C) are not accompanied by a decrease in protein stability or solubility. PloS One. 2014; 9 (4): e96150.

Petrlova J, Duong T, Cochran MC, et al. The fibrillogenic L178H variant of apolipoprotein A-I forms helical fibrils. J Lipid Res. 2012; 53(3):390-398

Pownall HJ, Massey JB, Kusserow SK, et al. Kinetics of lipid-protein interactions: interaction of apolipoprotein A-I from human plasma High Density Lipoproteins with phosphatidylcholines. Biochemistry. 1978;17 (7): 1183-1188.

Prieto ED, Ramella N, Cuellar LA, et al. Characterization of a human apolipoprotein A-I construct expressed in a bacterial system. Protein J. 2012; 31(8): 681-688.

Ramella NA, Rimoldi OJ, Prieto ED, et al. Human apolipoprotein A-I-derived amyloid: its association with atherosclerosis. PLoS One. 2011; 6(7):e22532.

Ramella NA, Andújar I, Ríos JL, et al. Human apolipoprotein A-I Gly26Arg stimulation of inflammatory responses via NF-kB activation: Potential roles in amyloidosis? Pathophysiology. 2018; 25 (4):397-404

Ramella NA, Schinella GR, Ferreira ST, et al. Human apolipoprotein A-I natural variants: molecular mechanisms underlying amyloidogenic propensity. PLoS One. 2012; 7(8):e43755.

Reixach N, Deechongkit S, Jiang X, et al. Tissue damage in the amyloidoses: Transthyretin monomers and nonnative oligomers are the major cytotoxic species in tissue culture. Proc. Natl Acad Sci (USA) 2004;101 (7): 2817-2822.

Rojo-León V, Aguilar-Cázares D, Prado-García H, et al. Participación de los patrones moleculares asociados al daño en el tratamiento convencional del cáncer. Revista de investigación clínica. 2012; 64 (3): 284-293.

Rosú SA, Rimoldi OJ, Prieto ED, et al. Amyloidogenic propensity of a natural variant of human apolipoprotein A-I: Stability and interaction with ligands. PLoS One. 2015; 10 (5):e0124946.

Rosú SA. Tesis doctoral en facultad de Ciencias Médicas; Relación estructurafunción patogenicidad de la Apolipoproteína A-I humana. 2017; Universidad Nacional de La Plata ed 
Rowczenio D, Dogan A., Theis JD et al. Amyloidogenicity and Clinical Phenotype Associated with Five Novel Mutations in Apolipoprotein A-I Amer J Pathol, 2011; 179 (4): 19878-19887.

Rumjon A, Coats T, Javaid MM. Review of eprodisate for the treatment of renal disease in AA amyloidosis. Int J Nephrol Renovasc Dis. 2012; 5:37-43.

Ryan RO, Forte TM and Oda MN. Optimized bacterial expression of human apolipoprotein A-I. Protein Expr Purif. 2003; 27(1):98-103.

Salnikov ES, Anantharamaiah GM and Bechinger B. Supramolecular organization of apolipoprotein-A-I-derived peptides within disc-like arrangements. Biophys J. 2018; 115 (3): 467-477.

Samillán-Sosa KDR, Sención-Martínez G, Lopes-Martín V, et al. Amiloidosis Renal hereditaria por depósito de Apolipoproteína A-I: un reto diagnóstico. Nefrologia 2015; 35(3):322-327

Scanu AM, Byrne RE, andEdelstein C. Proteolytic events affecting plasma apolipoproteins at the co- and post-translational levels and after maturation. $\mathrm{J}$ Lipid Res. 1984;25(13):1593-1602.

Scarpioni R and Obici L. Renal involvement in autoinflammatory diseases and inflammasome-mediated chronic kidney damage. Clin Exp Rheumatol. 2018; Suppl 110 (1): 54-60.

Schiffer $\mathbf{M}$ and Edmunson $\mathbf{A B}$. Use of helical wheels to represent the structures of proteins and to identify segments with helical potential. Biophys Journal. 1967; 7 (2):121-135.

Segrest JP, Jones MK, De Loof $\mathbf{H}$,et al. The amphipathic helix in the exchangeable apolipoproteins: A review of secondary structure and function. J Lipid Res. 1992; 33(2):141-166.

Shih A, Sligar SG and Schulten K. Maduration of high-density lipoproteins. J R Soc Interface. 2009; 6 (39):863-871

Solomon JP, Bourgault S and Powers ET. Heparin binds $8 \mathrm{kDa}$ Gelsolin cross$\beta$-sheet oligomers and accelerates amyloidogenesis by hastening fibril extension. Biochemistry. 2011; 50 (13): 2486-2498

Soutar AK, Hawkins PN, Vigushin DM, et al. Apolipoprotein Al mutation Arg60 causes autosomal dominant amyloidosis. Proc Natl Acad Sci U S A. 1992; 89: 7389-7393. 
Stokes MB, Holler S, Cui Y, et al. Expression of decorin, biglycan, and collagen type I in human renal fibrosing disease. Kidney Int. 2000; 57 (2):487-498

Stridh S, Palm F, and Hansell P. Renal interstitial hyaluronan: functional aspects during normal and pathological conditions. Am J Physiol Regul Integr Comp Physiol. 2012; 302 (11):R1235-1249.

Tougaard BG, Pedersen KV, Krag SR,et al. A case report of hereditary apolipoproteinA-I amyloidosis associated with a novel APOA1 mutation and variable phenotype. Eur J Med Genet. 2016; 59: 474-477.

Townsend D, Hughes E, Hussain R, et al. Heparin and methionine oxidation promote the formation of apolipoprotein A-I amyloid comprising $\alpha$-helical and $\beta$ sheet structures. Biochemistry. 2017; 56 (2):1632-1644.

Van Allen MW, Frohlich JA and Davis JR. Inherited predisposition to generalized amyloidosis. Clinical and pathological study of a family with neuropathy, nephropathy, and peptic ulcer. Neurology. 1969; 19 (1): 10-25.

Vermeer LS, Hamon L, Schirer A, et al. Vectofusin-1, a potent peptidic enhancer of viral gene transfer forms $\mathrm{pH}$ dependent $\alpha$-helical nanofibrils, concentrating viral particles. Acta Biomater. 2017; 64: 259-268.

Vilbig RL, Sarkar A, Zischkau J, et al. An online tool for calculation of freeenergy balance for the renal inner medulla. Am J Renal Physiol. 2012; 303 (3):F366-372

Wechalekar AD, Gillmore J and Hawkins PN. Systemic amyloidosis. Lancet. 2016; 387 (10038):2641-2654.

Witkowski A, Carta S, Lu R, et al. Oxidation of methionine residues in human apolipoprotein A-I generates a potent pro-inflammatory molecule. J Biol Chem. 2019; 294 (10):3634-3646.

Witkowski A, Chan GKL, Boatz J, et al. Methionine oxidized apolipoprotein A-I at the crossroads of HDL biogenesis and amyloid formation. FASEB J. 2018; 32 (6):3149-3165.

Xu B, Gillard BK, Gotto Jr AM, et al. ABCA1-derived nascent high density lipoprotein-Apo Al and lipids metabolically segregate. Arterioscler Thromb Vasc Biol. 2017; 37(12):2260-2270. 
Zakiyanov O, Kalousová M, Zima T, et al. Matrix metalloproteinases in renal diseases: A critical appraisal. Kidney Blood Press Res. 2019;44(3):298-330.

Zhang X, Li J. Heparan Sulfate Proteoglycans in Amyloidosis. Vol 93. 1st ed. Elsevier Inc.; 2010. doi:10.1016/S1877-1173(10)93013-5.

Zhao GJ, Yin K, Fu YC, et al. The Interaction of ApoA-I and ABCA1 triggers signal transduction pathways to mediate efflux of cellular lipids. Mol Med. 2012; 18:149-158

Zhao H, Tuominen EKJ and Kinnunen PKJ. Formation of amyloid fibers triggered by phosphatidylserine-containing membranes. Biochemistry 2004; 43 (32), 10302-10307

Zhu HL and Atkinson D. Conformation and lipid binding of a C-terminal (198243) peptide of human apolipoprotein A-I. Biochemistry. 2007; 46(6): 1624-1634. 